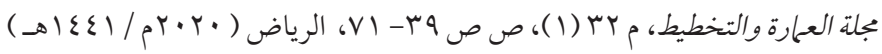

doi:10.33948/JAP-KSU-32-1-2

\title{
بلاغة الشكل في العمارة الإسلامية: دراسة تحليلية لأسلوب الإطناب
}

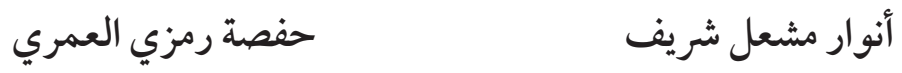 \\ أستاذ

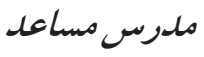 \\ قسم المندسة المعلارية، جامعة الموصل \\ Anwar_shareef@yahoo.com \\ قدم للنشر في Y // / • ع ع هـ ـ وقبل للنشر في 9 / / / • ع ع هـ
}

ملخص البحث. تعد العمارة الإسلامية مثالاً متميزاً تعكس نتاجاتها البلاغة من خلال أسلوب نظمها. و البلاغة مفهوم حظي باهتحام المنظرين والمعحارين وقدم في تفسيره إسهامات عدة انصبت على المعاني و الصور

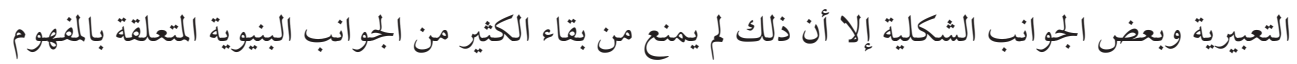

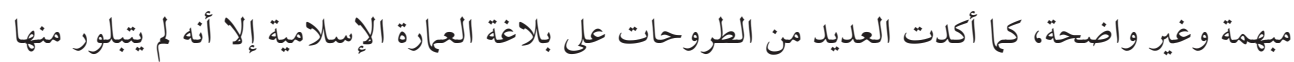

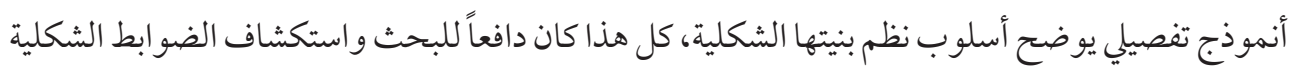
التي كانت وراء البلاغة في العمارة الإسلامية، واستدعى ذلك التوجه إلى الدراسات اللغوية وتحديد المشكلة البحثية بالتركيز على أحد أهم الأساليب البلاغية وهو الإطناب وتحديد مفردته الأساسية (الزيادة الكمية)،

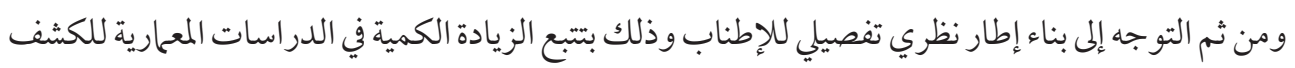

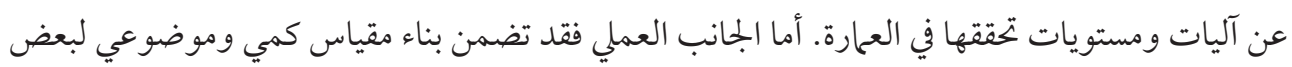
مفردات الإطناب ومقياس وصفي لمفردات أخرى وتحدد نطاق الاختبار بالو اجهات الداخلية لمجموعة من فئن

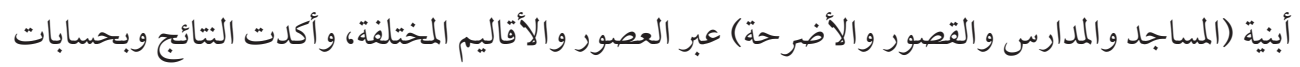

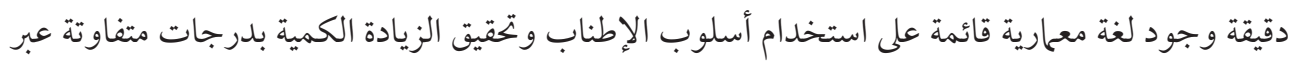

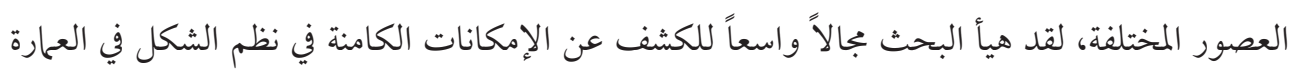

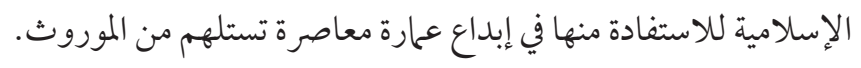

الكلمات المفتاحية: البلاغة، الشكل، العمارة الإسلامية، الإطناب. 
Jean-Marc Castera - 2006 دراسة 1, , ,

(The Muqarnas Dom Of The Two Sisters In

The Alhambra In Granada)

عَرضــت الدراســة التأثـــرات الشــعرية

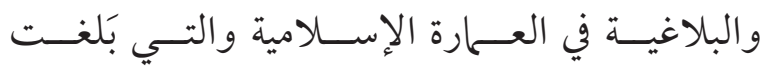

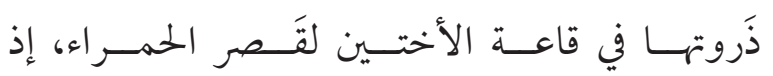

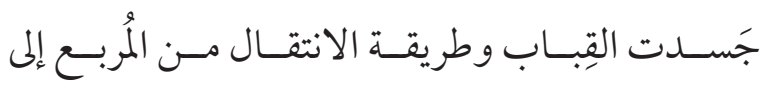

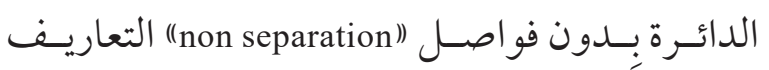

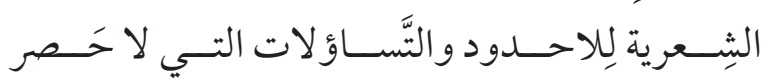

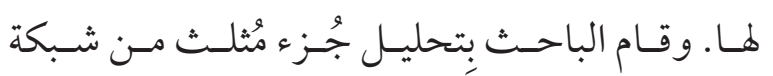

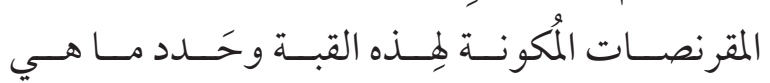
التَّحــولات التـي حَصلـت عـلى مُفــردة المقرنـص مسن

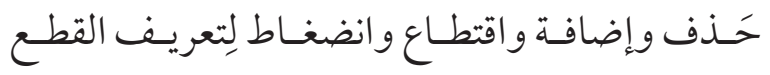
الرئيسـية التـي تشـكلت منهــا القبـة، إذ تنتظــم هــــهـ

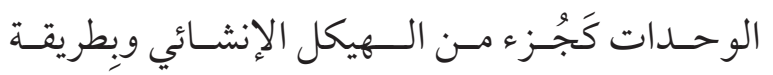

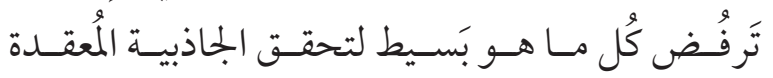

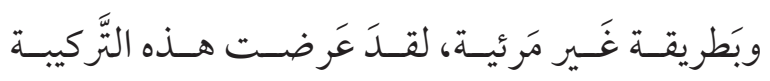

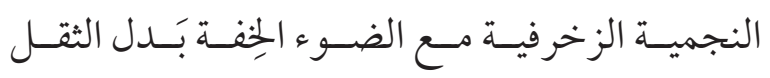

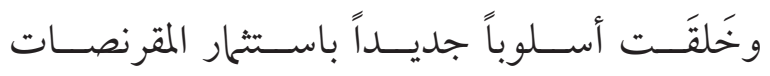

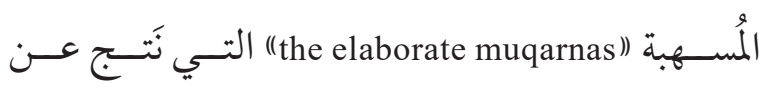

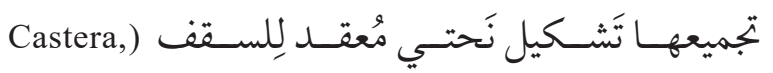

(2006

Richard-Yeomans- 2006 , 1 , 1 دراسة (The Art And Architecture Of Islamic Cairo)

أشــارت الدراســة إلى أن بلاغــة العــارة

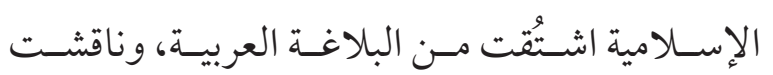

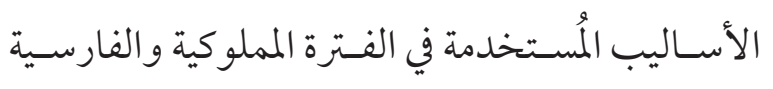

ا ـ المحور الأول: بلاغة الشكل في العجارة الإسلامية: 1 , 1 دراسات تناولت البلاغة في العمارة الإسلامية: To-Tonna -1990 د, 1, , 1, (The Poetics Of Arab-Islamic Architecture) اتسـمت العـارة الإســلامية بالبلاغـة المعلماريـة كطُــرق وقو اعــد تركيبيــة مُناظــــة لتلــك التــي

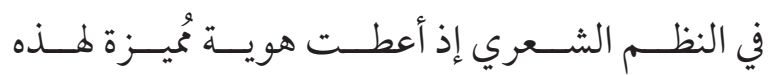

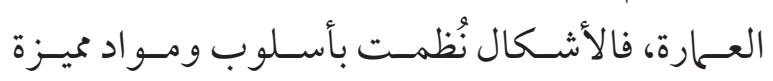

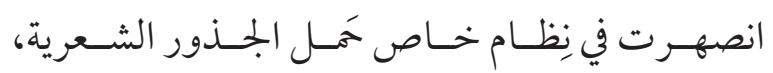

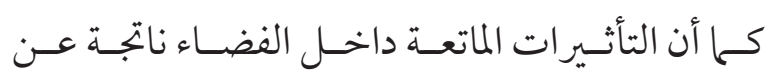
تكوينات الـــيكل الإنشـائي وخطوط المنشـأ المُشـتقة

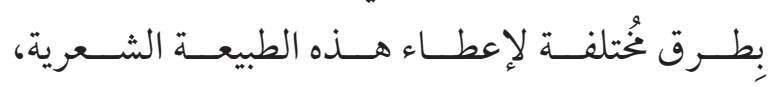

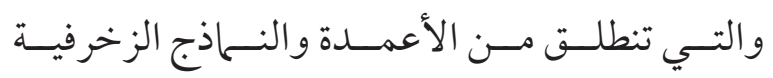

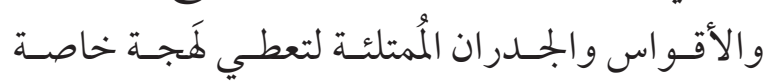

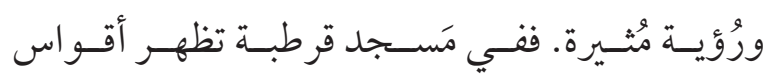

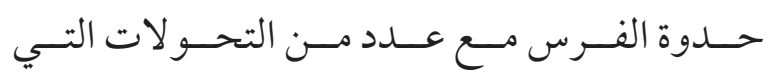
تجـري عليهـا واسـتخدام طريقـة خاصسة في تجميعهـا

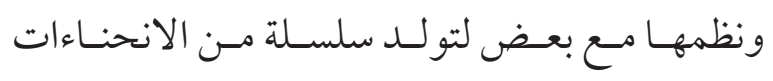

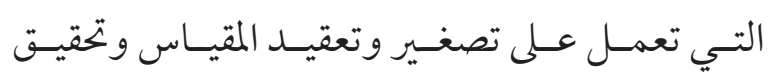

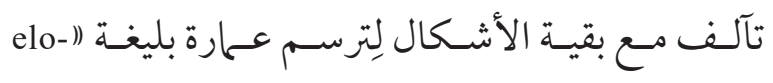

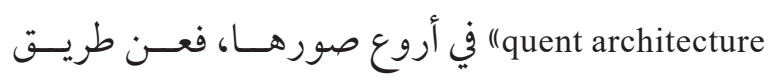
سلسـلة مــن التحـــولات التـي تجـــي عـلى العنـاصر

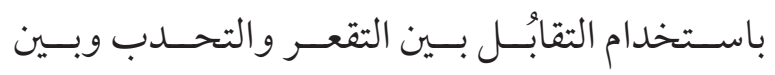

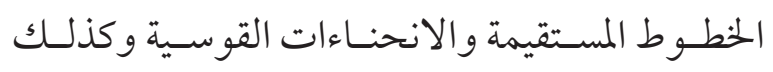

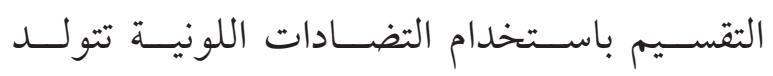
الجاذبيـة المعقــدة التـي عرفـت عبقريـة وغنسى العـارة الإســلامية (To-Tonna, 1990). 


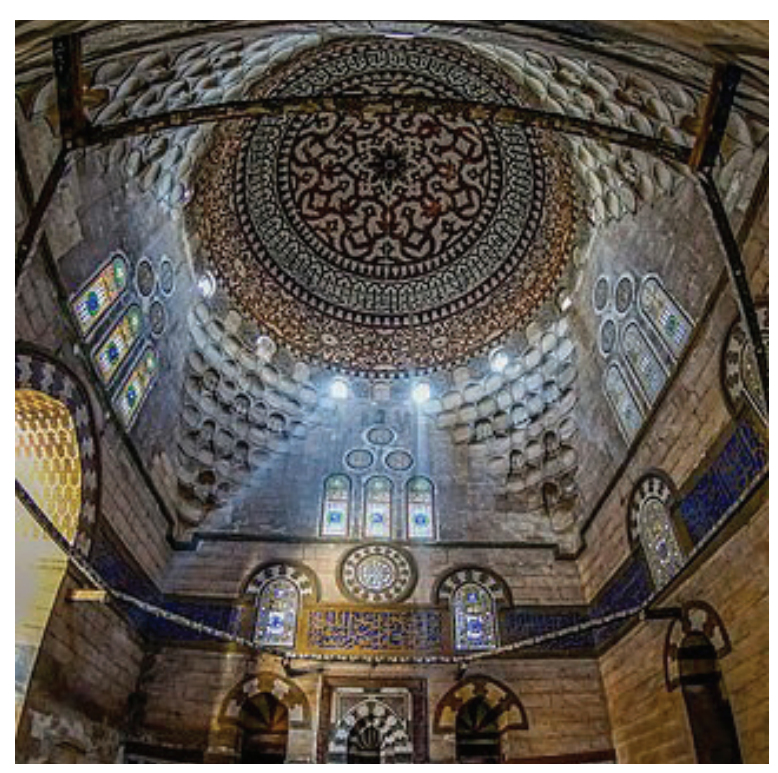

الشكل رقم (1). مدرسة فرج ابن برقوق.

التأكيــد عــلى دور التفاصيـل الزخرفيــة والســطوح

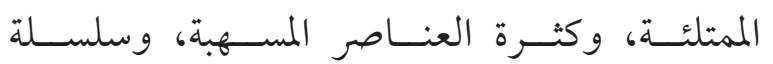
التحـــولات التـي تجــري عـلى بعـــ العنـــاصر،

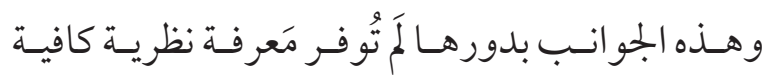

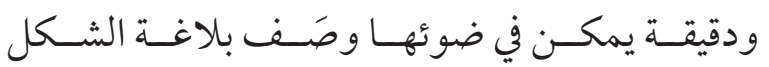

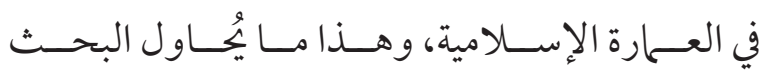
الكشـف عنـهـ. وخَلــص الباحـث إلى ضَرورة التَّ جـهـ

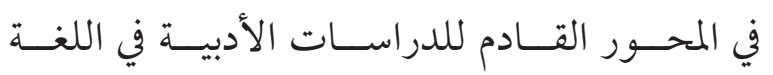
للتو صـل إلى تفسـير واضـح لبنيـة النـص البلاغـي. r. المحور الثاني: استخلاص الأطر الكامنة للبلاغة في

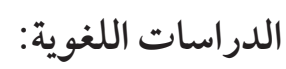

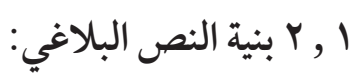

تعتمـــد الإجـــراءات التـــي تتخذهــــا بلاغـــة الخطـاب ويتبناهــا علــم النــص بالتـــرج مــن الأبنيـة الصغــىى إلى الكـــىى، حتى تصـل إلى النـص بأكمله
و العثمانيـة، وأكـــت أن إطـار العمــل المعــاري لِنَظــم

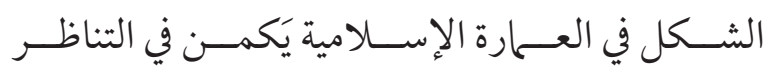

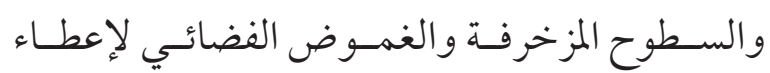

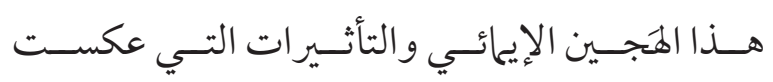

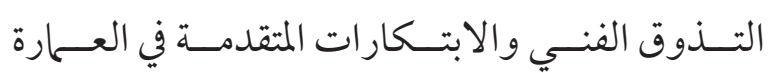

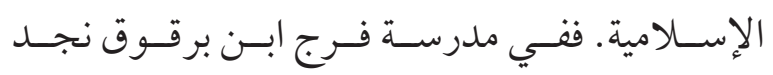

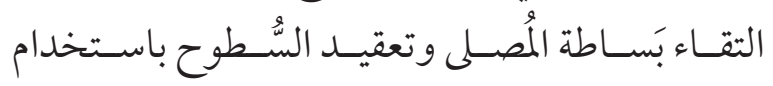

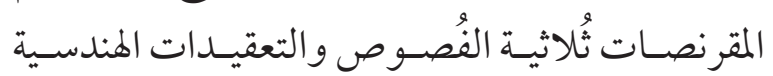

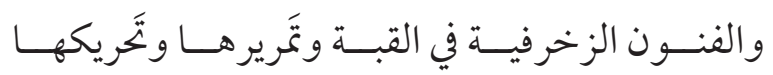

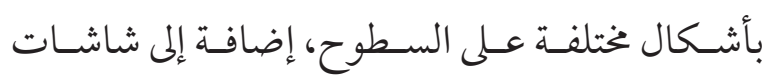

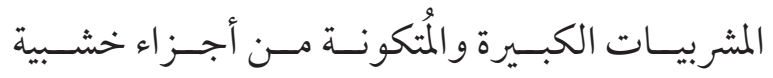

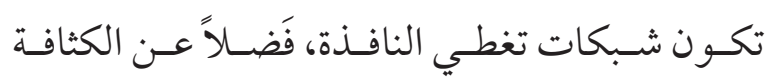

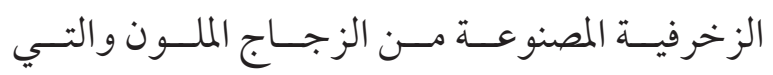

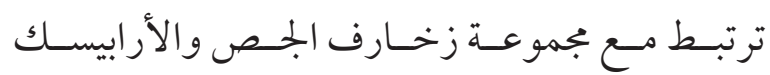

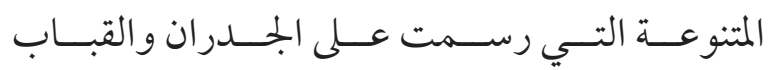

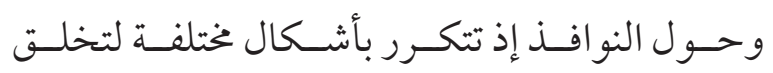

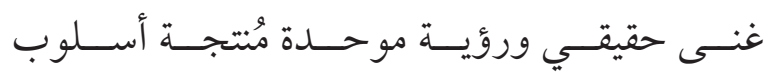

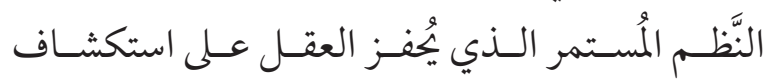

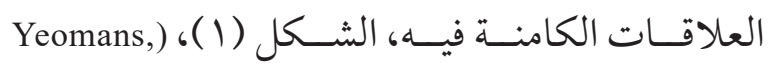
.(2006 r , ا نقد الدراسات وتحديد المشكلة البحثية: إن الجموانـــب التــي طرحتهــــا الدراســات في

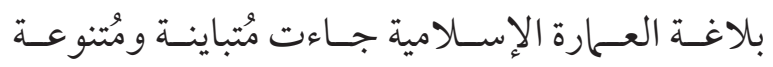

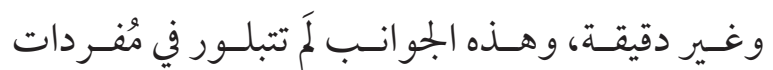

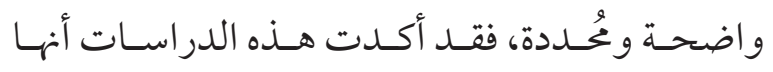
عـــارة حملــت البلاغـــة في ثناياهـــــا إلا أن مفرداتهــــا جـاءت عامـة أو مُقتــصرة عـلى جو انـبـ معينـة، منهــا 
بــكل تفصيسلي وصريـح، تحــدد هـدف البحــث في

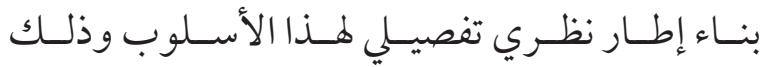

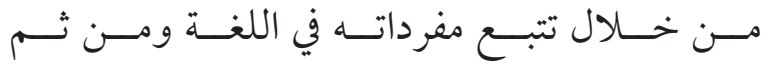

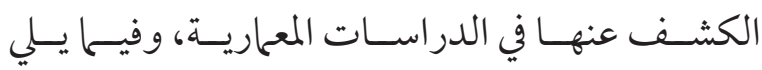

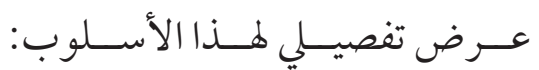

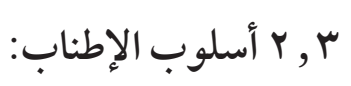

الإطنــاب: هـو الإطالــة لغايسـة معـد هــــ

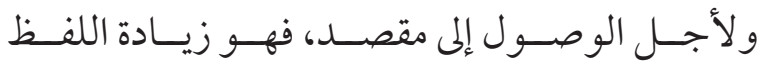

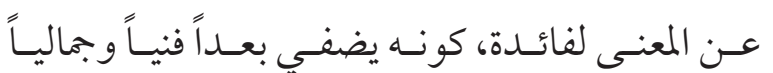

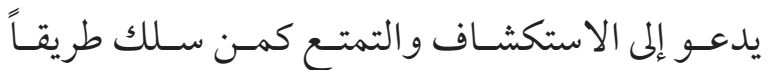

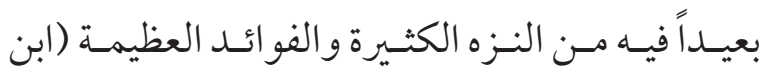

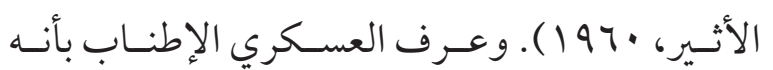

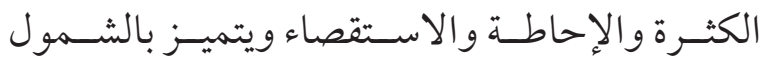

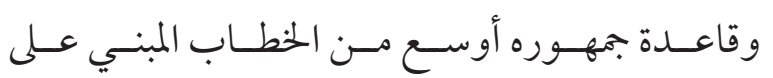

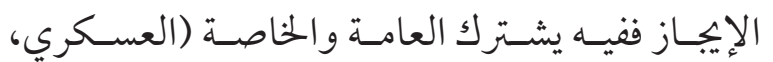

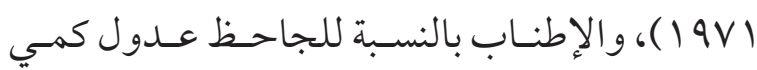

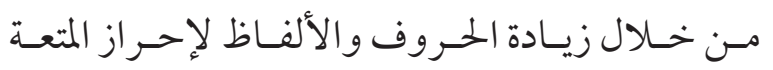

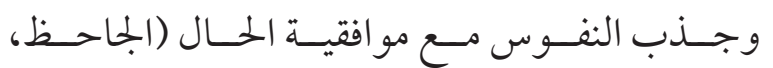

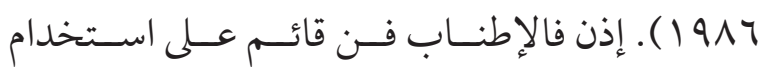

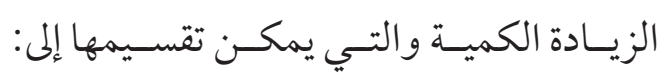

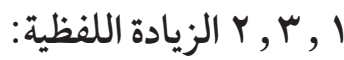

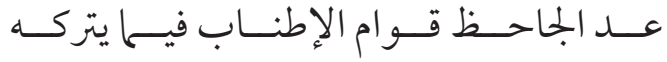

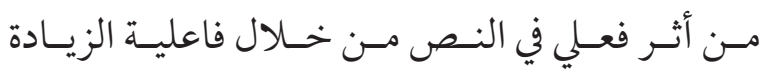

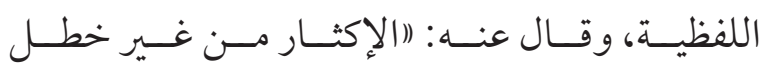

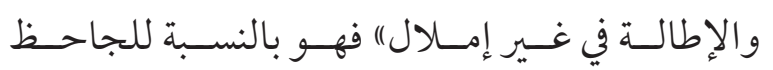

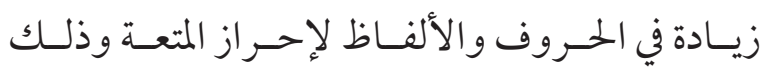

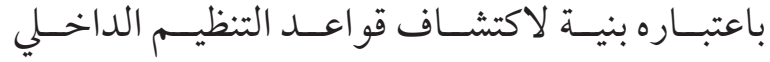

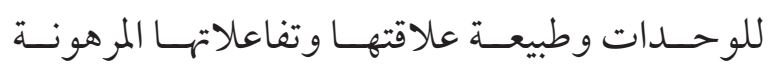

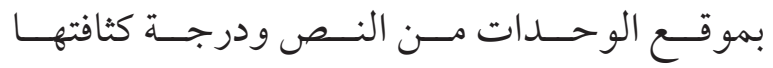

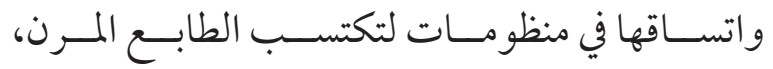

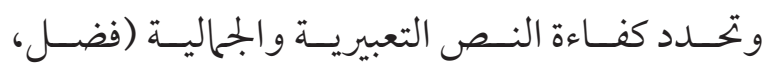

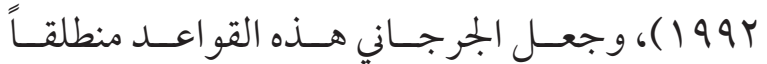

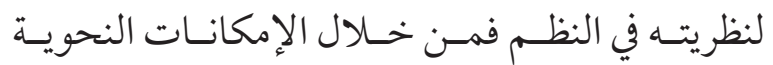

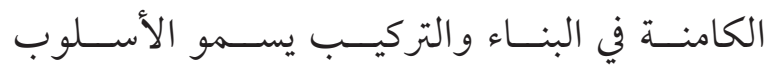

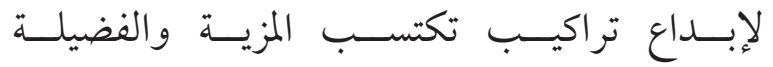

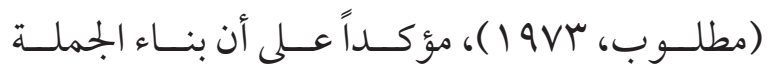
وتركيـب النـص يكمـن فيـا يجصـل عليـه مـن ذكـر

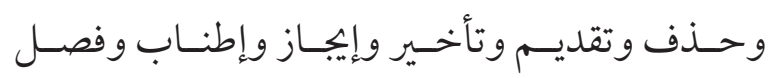

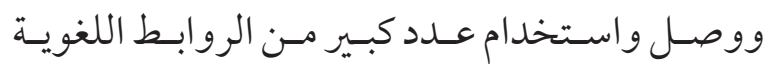

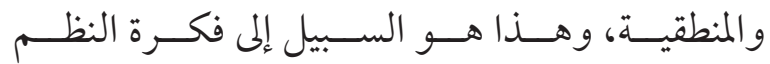

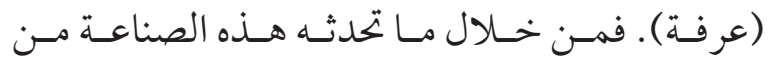
تغيـيرات عـلى البنيـة الداخليـة للنـص يتحقـق عطـاء

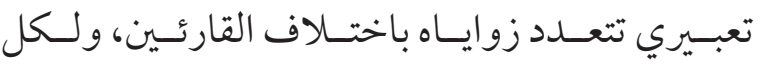

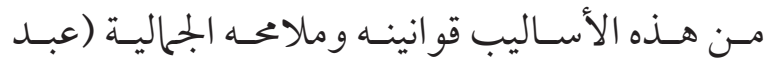

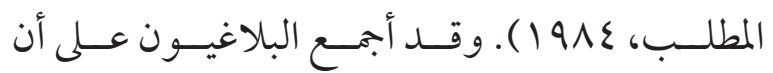

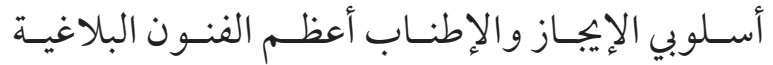

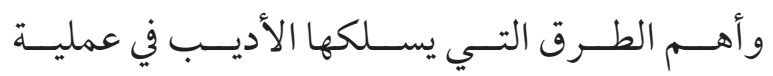

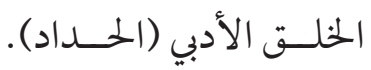

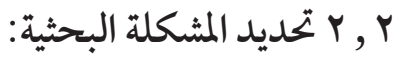

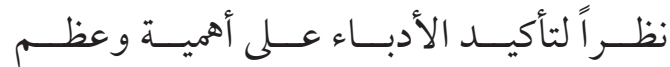

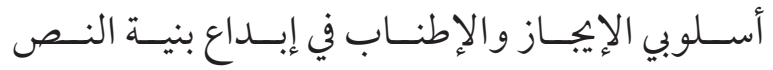

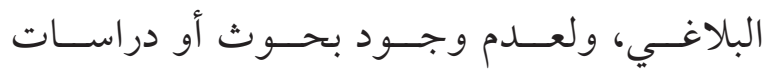
معماريسة تناولــت أســلوب الإطنــاب في العـلـارة 
للخلـق لتحقـق التأثــــ الوجــاني ولبيـان دقـة العلـم

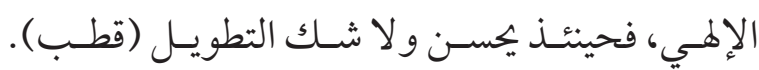

ع , r كيفية قياس الإطناب في الدراسات اللغوية:

لقـــــ أثــارت الدراســات اللغويــة إلى أن

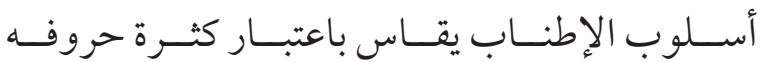

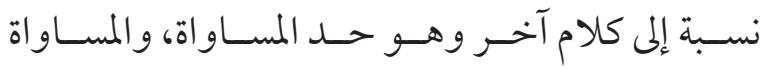

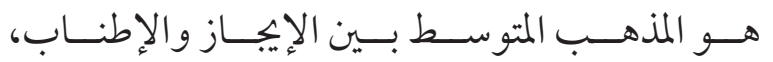

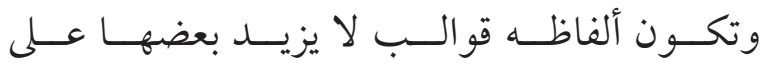

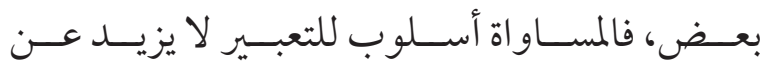

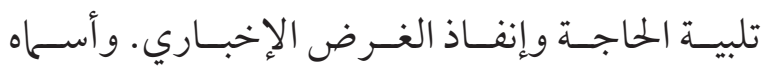

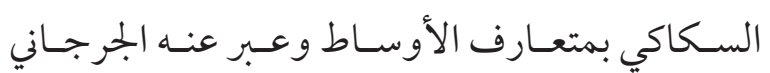

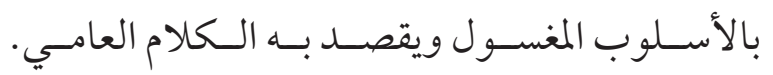

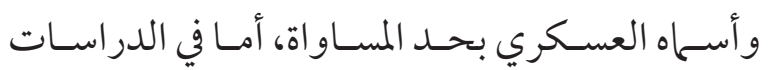

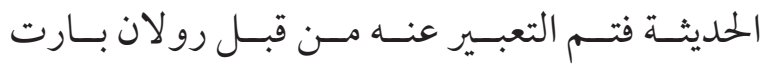

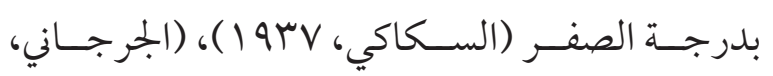

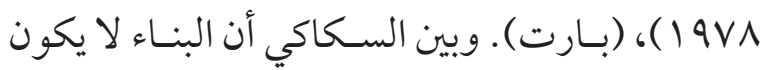

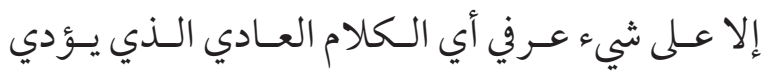

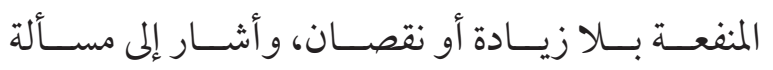

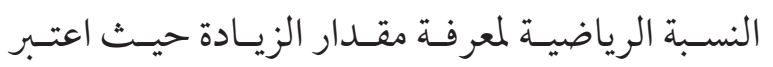

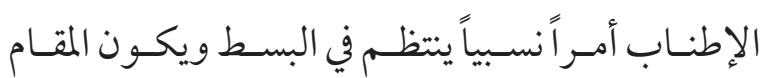

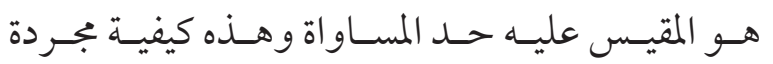

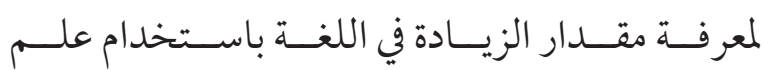

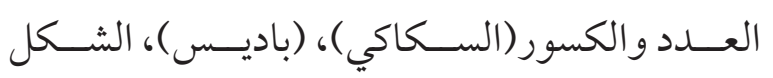

نسـتنتج مـــا ســق أن مقـــار الزيــادة الكميـة الحاصلــة عـلى بنيـة النـص تقــاس نسـبة إلى معيـار

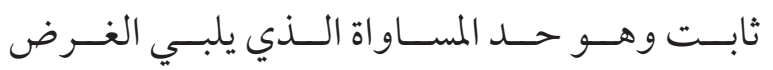

بالتوسـع عــن أصـل الجملـــة لتحقيـق الإفــادة

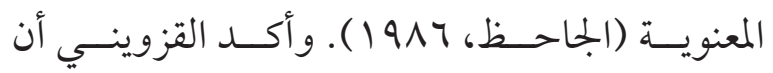

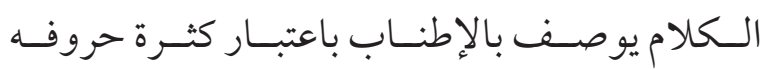

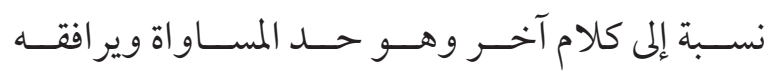

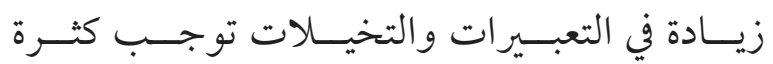

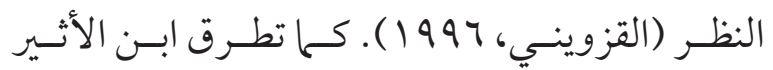

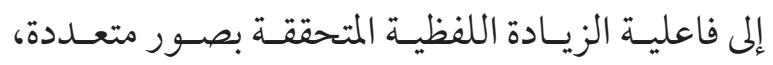

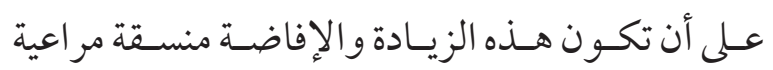

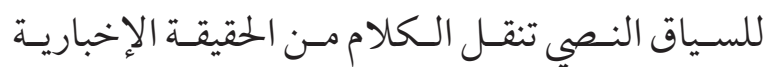

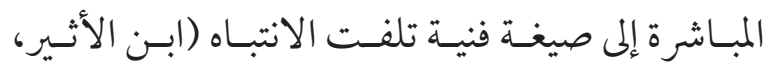

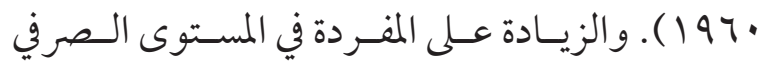

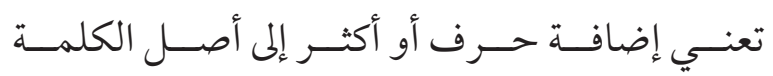

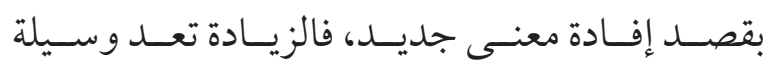

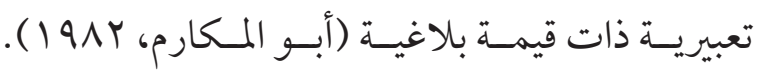
r r r r r الزيادة والإطالة بالتفصيلات: تكــون هـــه الزيـادة بتفصيـل القـول لا بإجماله

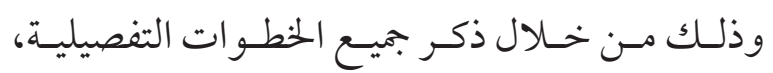

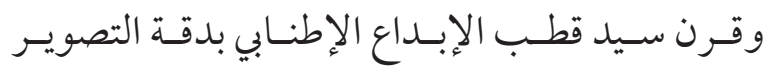

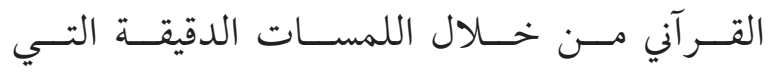

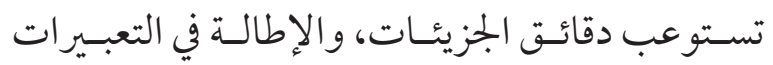

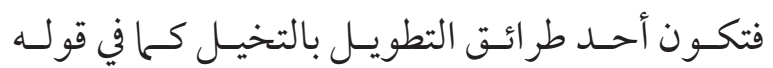

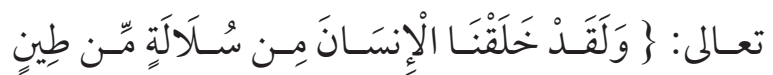

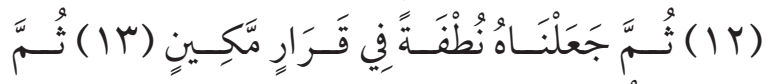

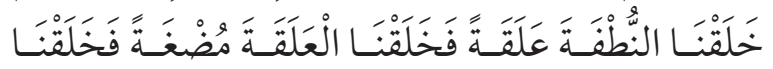

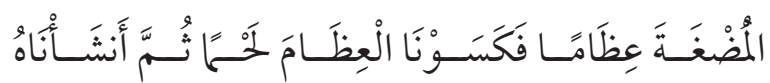

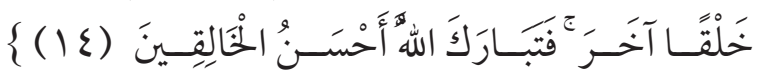

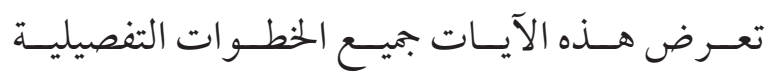




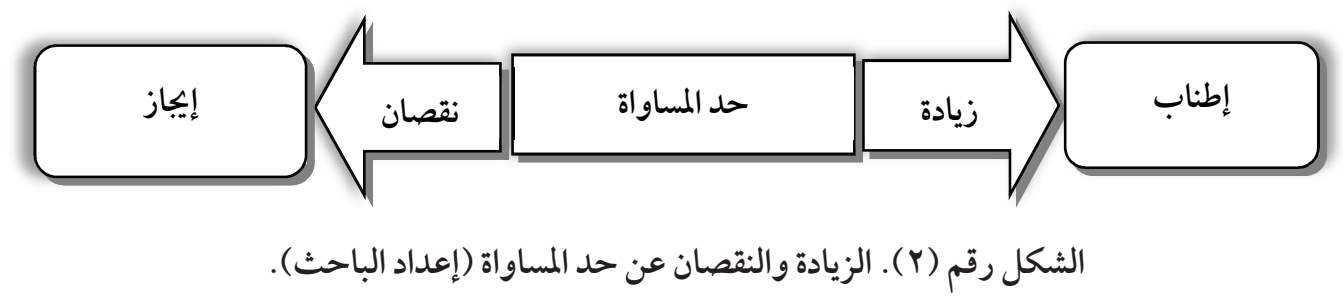

الجــدار المســطح الحامـل للثقـل كسلسـلة الأعمــدة

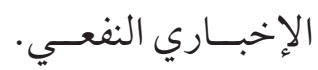

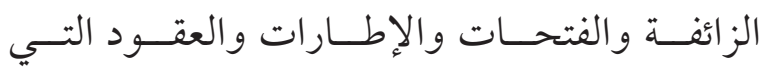

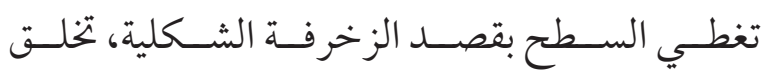

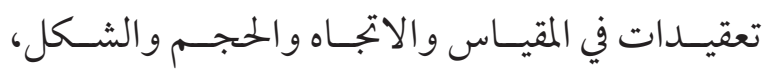
r. المحور الثالث: البناء النظري لأسلوب الإطناب

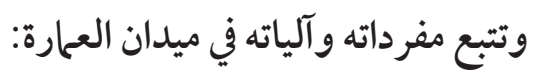
وتجعــل بإمــكان أي جــدار أن يضــم فضــاء داخــل نفسـه، فالعنــاصر الزائفــة المضافــة إلى البنيـة ســـواء

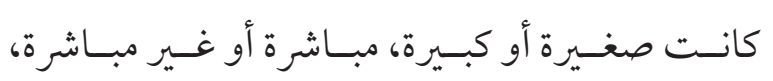

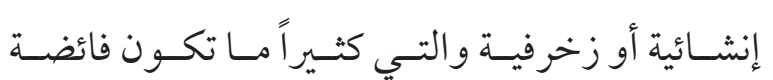

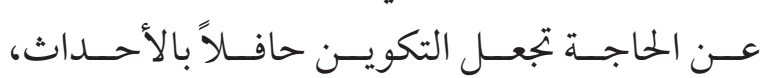

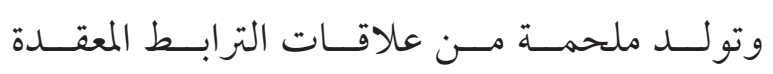
increas-» (Venturi,1977)

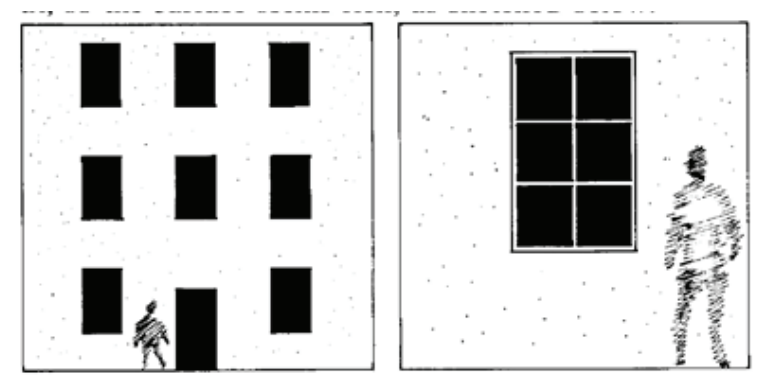

الشكل رقم (r). توضح وفرة العناصر (Bentley,1985).

es في عـدد العنــاصر الموجــودة عـلى السـطح كونهـا

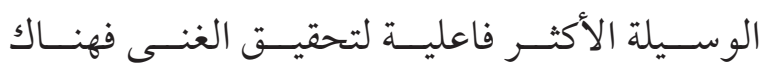

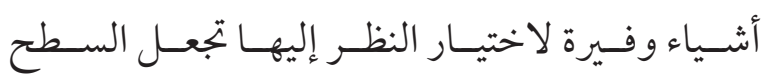

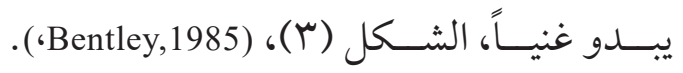
كــا تَضمسـن ميتشــيل في دراســته (-) The log
ا ب الزيادة الكمية في ميدان العمارة:

جــاء في لســان العــرب تعريــف الزيــادة:

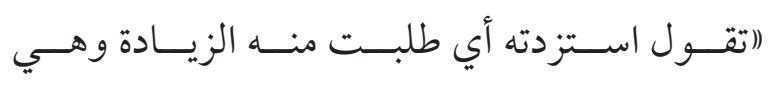

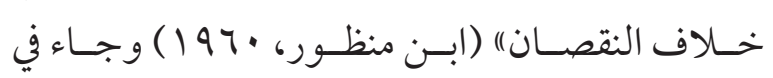
القامــوس المحيــط (الزيــادة والمزيــــ النمــو، وزاده

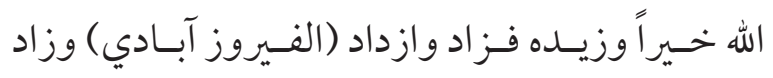

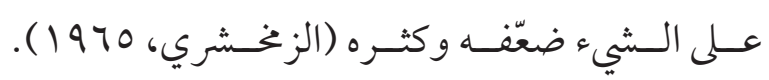
لقــــد تطرقـت بعــض الدر اســات المعلماريـــة

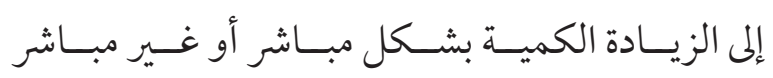

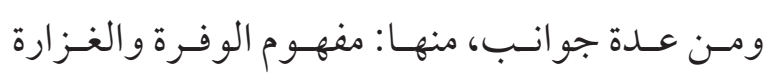
(redundant)

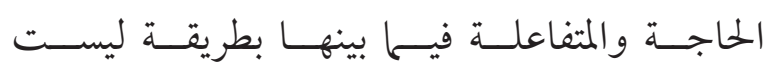

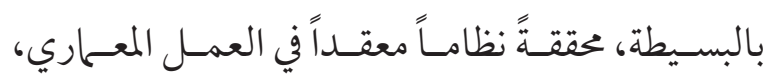

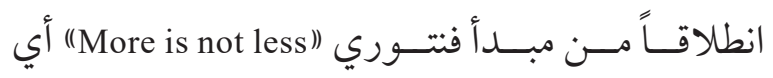

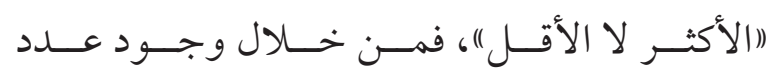

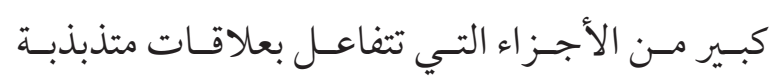

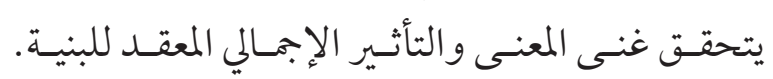

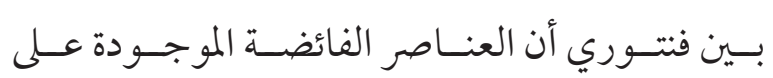




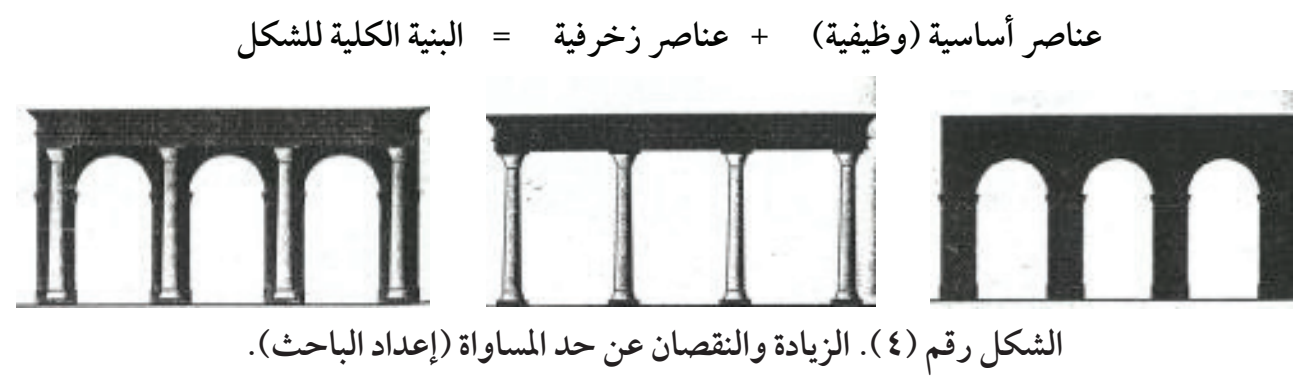

عسلى مَسر تاريــخ العـارة الإسـلامية، وفي كُل إعـادة

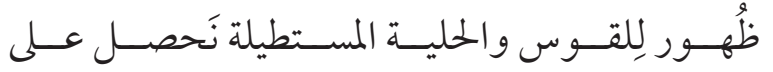

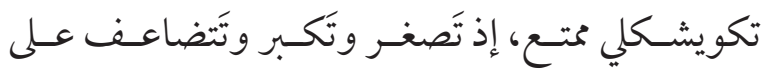

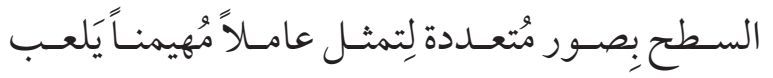

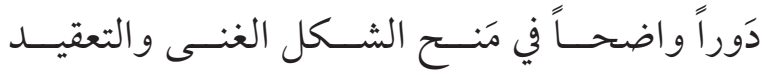

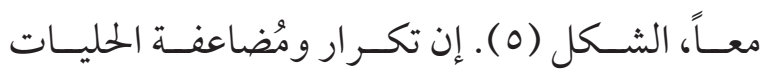

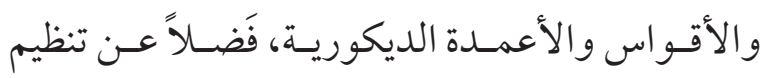

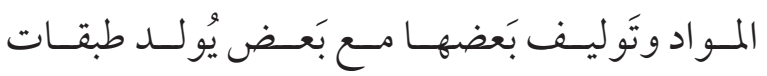

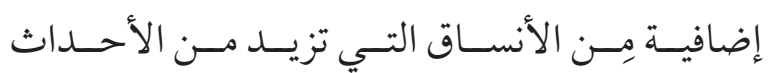

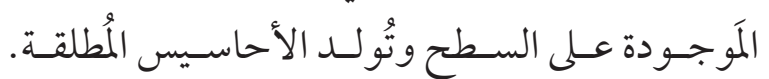

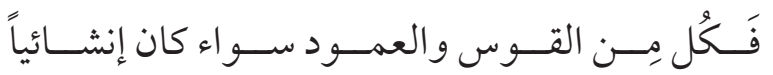
ornamen-) أو زخرفيـاً (structural-load-bearing) يَعمـل كَحليـة تلعـب دوراً (tal-non-load-bearing

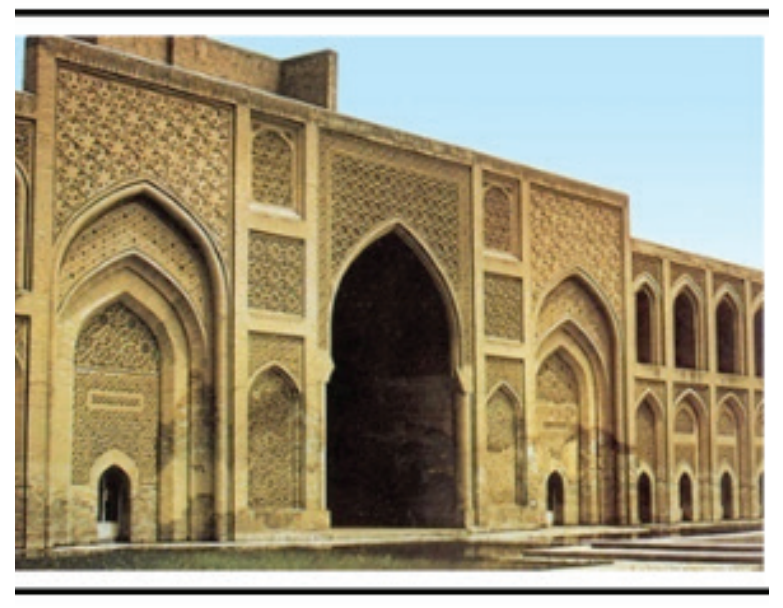

الشكل رقم (ه) . مدرسة المستنصرية (Michell,1978).
إمكانيــة تعريـف قو اعـــ تجميـع (ic of Architecture

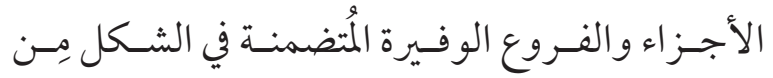

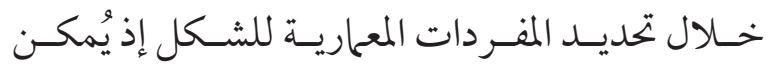

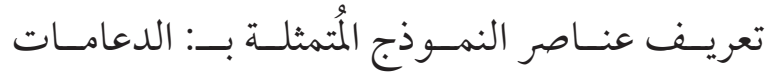

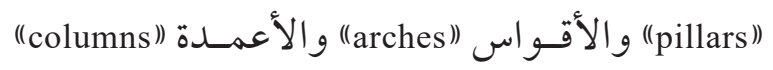

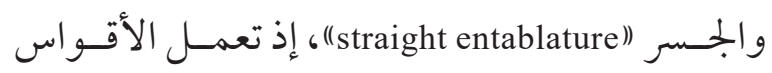

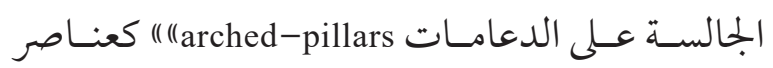

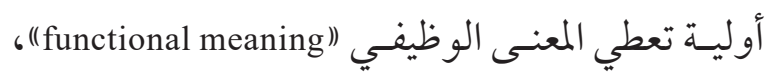

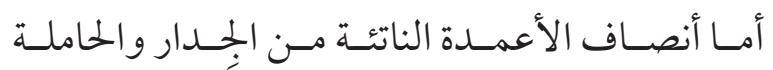

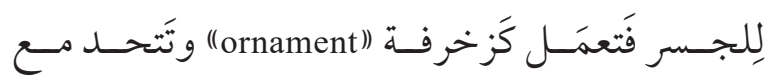
العنـاصر الوظيفيـة مُكونـة الشـكل (Mitchell,1992)

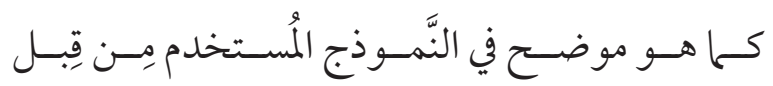

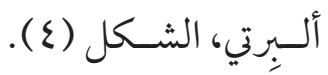

تضمنــت نتاجــات العِــارة الإسـلامية

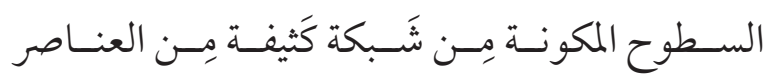

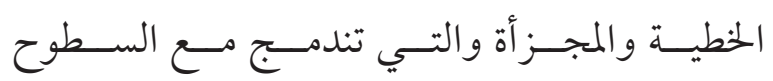

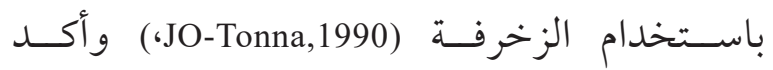

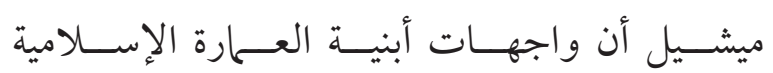

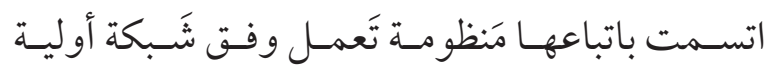

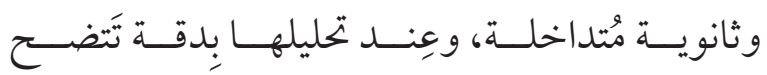

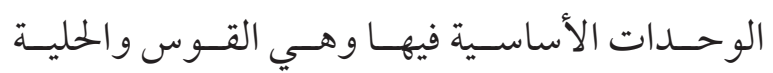

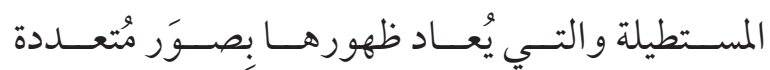




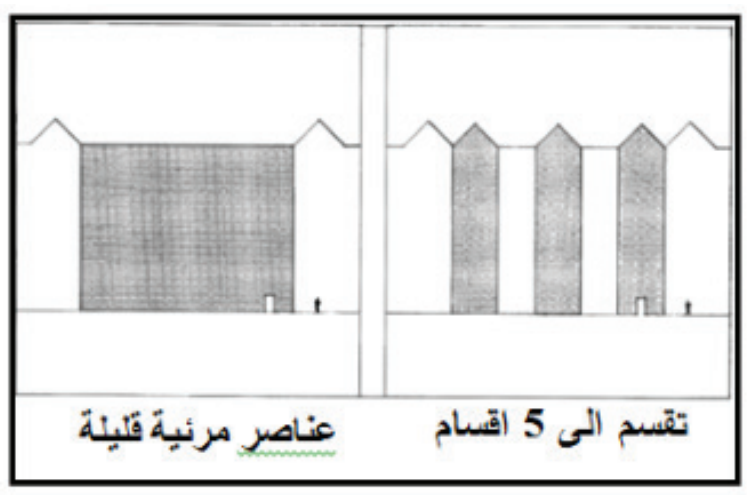

الشكل رقم (ج ). تقسيم البنية (Bentley، 1985).

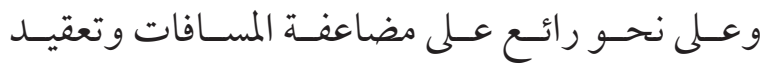

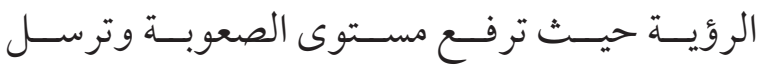
العـين للبحـث و التنقيـب المشـوق (Harbison,2009).

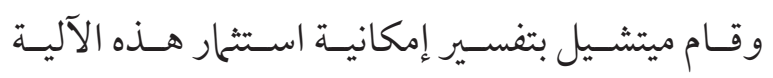

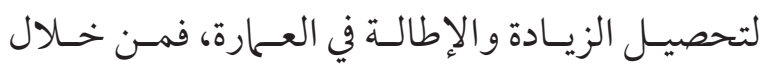

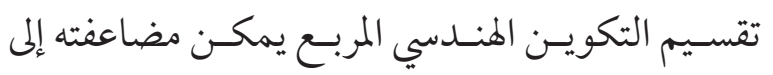

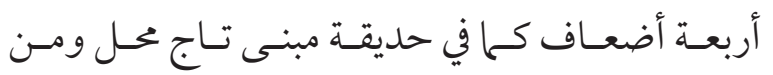

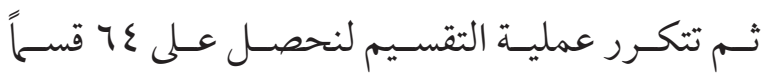

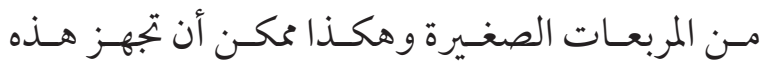

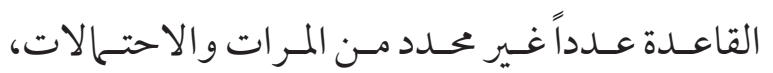

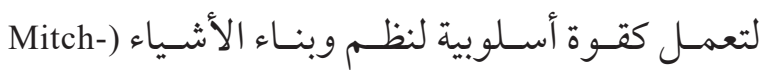

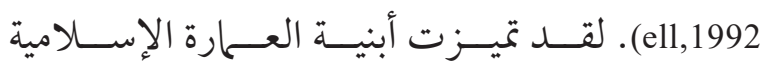

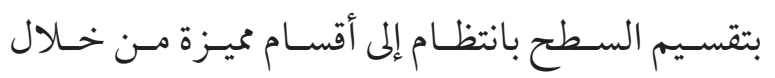

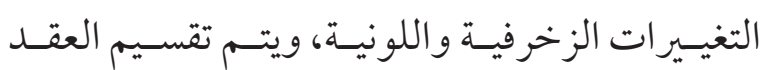
الو احســ كـا في مسـجد قرطبـة إلى مســاحات متبادلـة

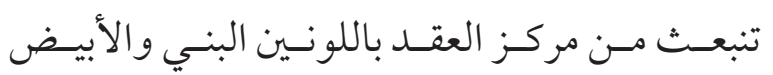

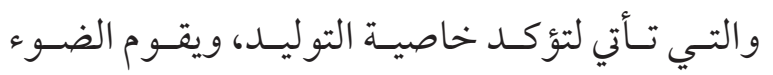

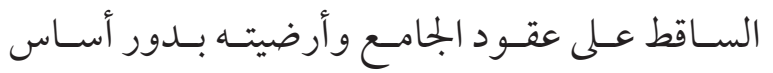

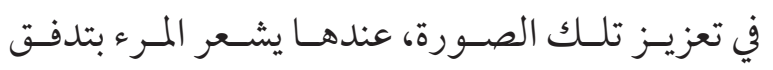

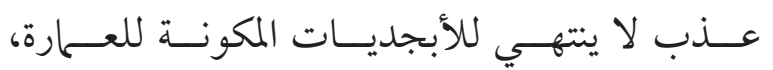

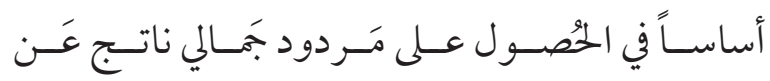
العنــاصر ذاتهــا (Mitchell,1978).

يســتنتج مـــا ســـق إمكانيــة إنتــاج الزيــادة

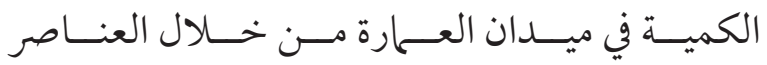

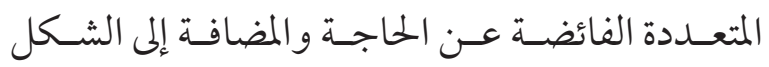

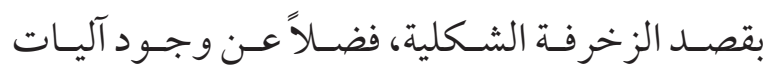
فرعيـة تعمـل عـلى زيــادة ومضاعفة الشـكل، وسـيتم دراسـتها والتعـرف إليهـا بشـكل تفصيـلي وكــا يـلي: r r r آليات تحقيق الزيادة: تــم تتبـع آليـات تحقيـق الزيــادة في الدراسـات المعماريـة وتمكـن البحـث مـن تبويبهـا كـا يـلي:

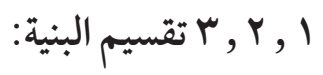
initial) ينتـج عـن تقسـيم الوحسـدة الأساسـيـة

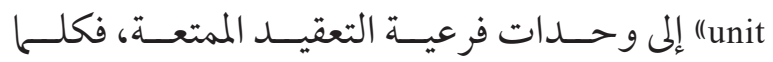
ازدادت البنـى زادت المعلومــات الموجــودة في الشـكل

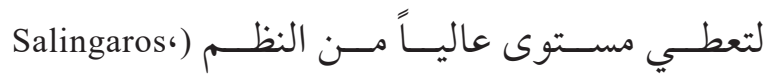

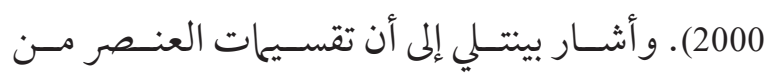

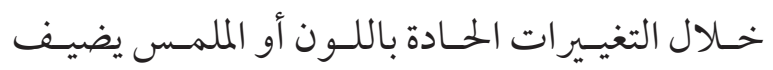

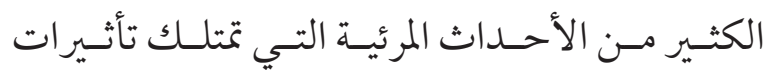
ببعديـن، أمـا إذا كانـت هذه التغيـيرات ثلاثيـة الأبعاد

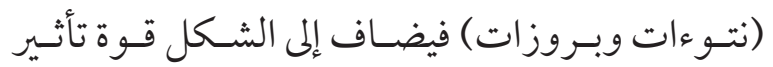
الضـوء و الظـل لتظهــر تضــادات حــادة والتـي تعـد مهمــة لتحقيـت مسـتوى عـالٍ مــن الغنـى وإضـافـة أحسـاث مرئيـة أكثـر، الشـكل (7) )، (Bentley,1985). كـا بــنـن هاربسـون أن وضـع علامـات تقســم البنيـة (Marking off the divisions of structure "تعمل 

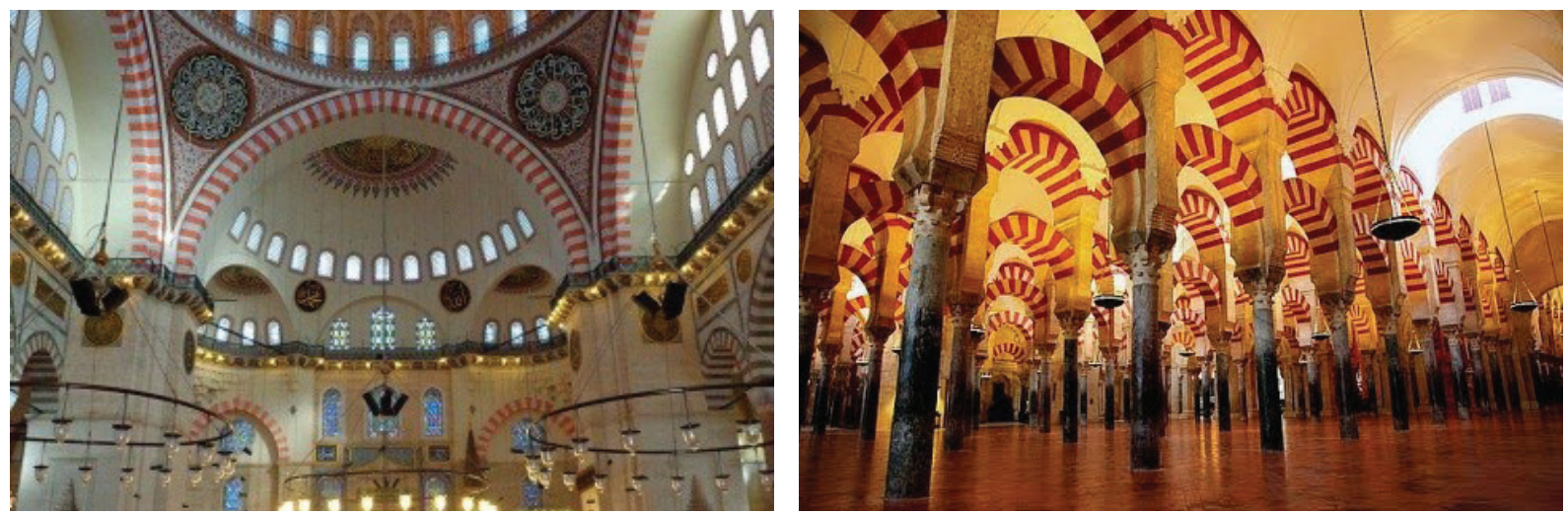

الشكل رقم (V) . مسجد قرطبة و السليمانية وتقسيم العقود باستخدام علامات لونية (القحطاني، 9 ، . Y ).

(sub shapes)"

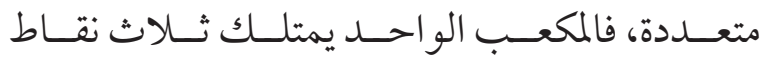

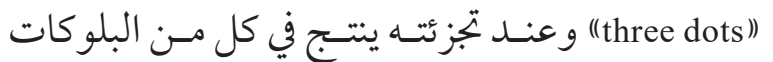
المكعبـة الصغــرة ثـلاث نقــاط، وهــو مـا يمنــح رؤية

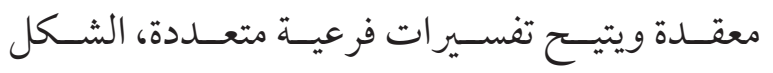
(9)، (9itchell,1992)، فعمليـة تفكيـك اكلكل ينتـج

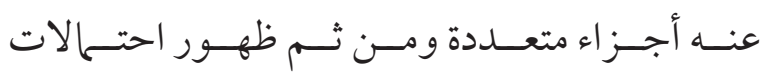
جديــدة في الفيــكل التكوينــي للشـــل (الإمــــام، $(r \cdot r$

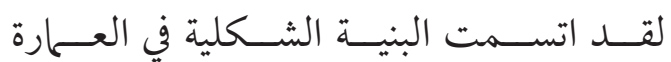

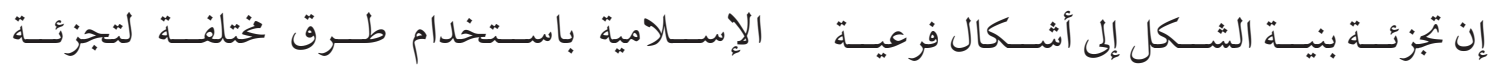

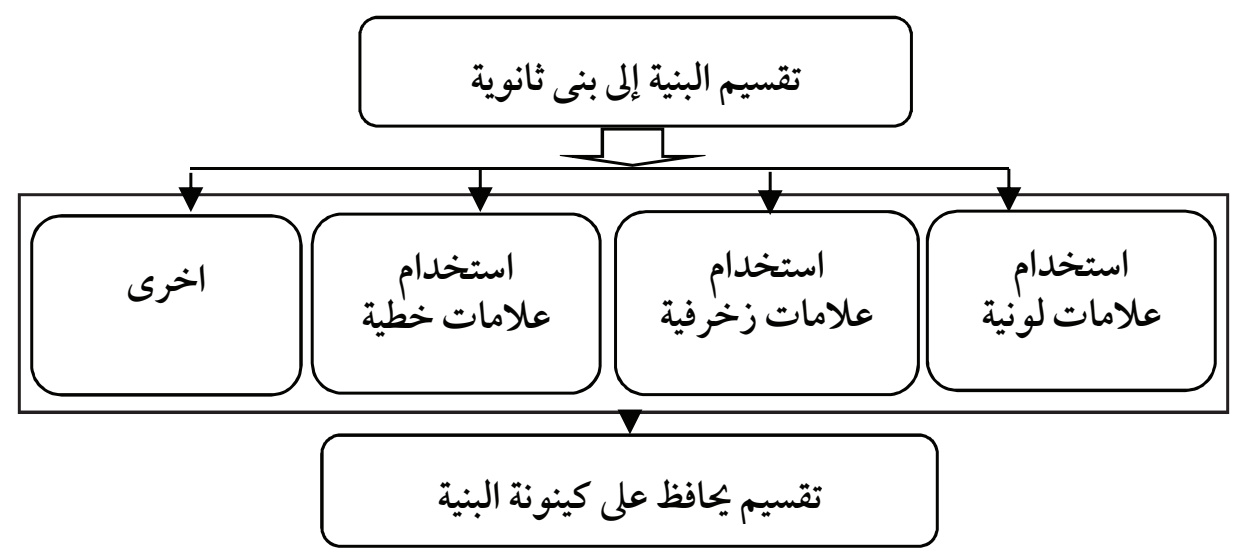

الشكل رقم (1) . يوضح آليات تقسيم البنية (إعداد الباحث). 


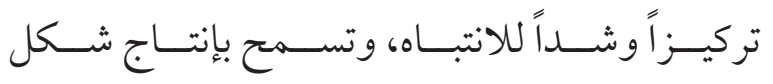

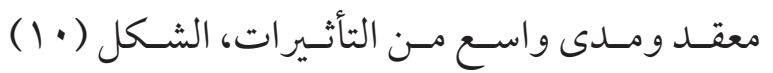

.(Hoag, 1975)

يتّضـح حمّا ورد سـابقاً أن تجزئـة البنية الشـكلية

وسـيلة لتحصيـل تعدديـة الأجـزاء في العـارة والتي لتي

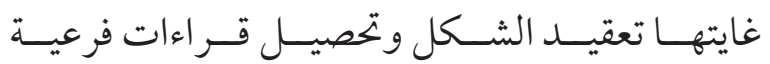
متعـددة وبقــرارات تصميميـة متنوعـة، فهي وسـيلة فعالـة لتحقيـت الزيـادة.

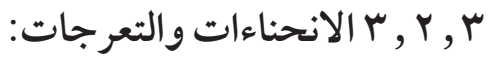

الخـط المتعـرج (Zig Zag) هــ عــد كبـير مـن

الخطـو ط المسـتقيمة ويمتلـك مســاحة معلو مـات أكبر

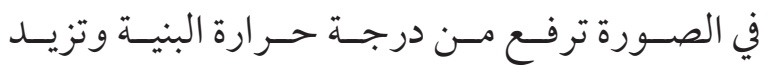
مـن تعقيدهــا لتعـزز الاسـتجابة تجـاه المبنـى فالأشـياء

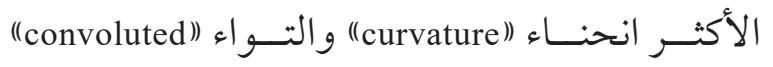
تمتلك تأثــــرات بصــــــرية عاليـة (Salingaros,1997)،

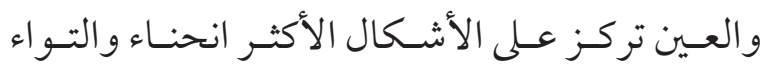

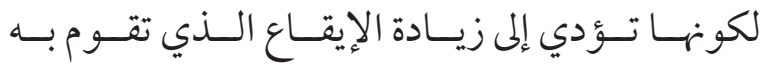

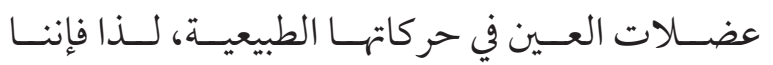
نشـــر بالشـــــــــاه تلــك الأشــكال (إبراهيـــم،

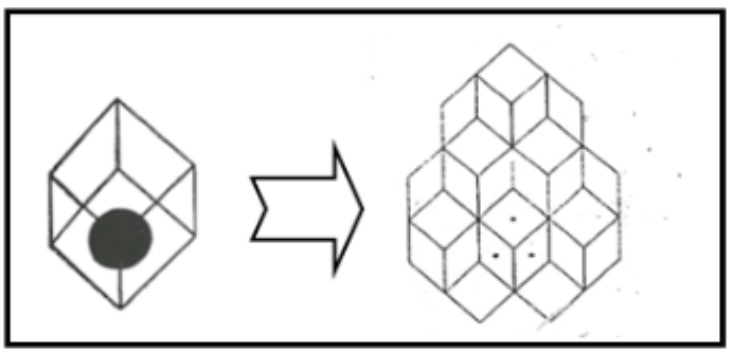

الشكل رقم (9) ). تجزئة المكعب إلى مكعبات صغيرة (-Mitch .(ell,1992

التكويــن مـن الناحيـة الحســية و البصريسـة، فالقبـة

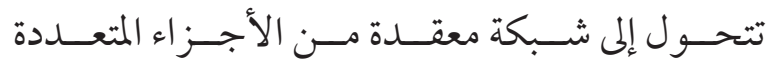
المولـدة لســطحها الداخــلي (Michell,1978)، كـــا في

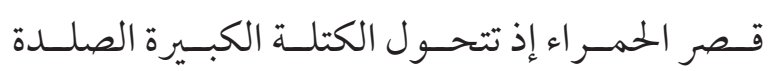

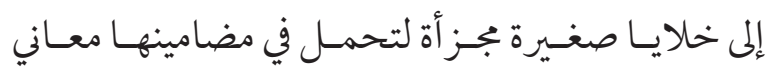

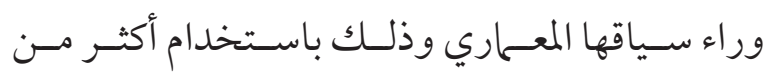
• . . . م قطعـة مسن المقرنصـات المتتجـة لصسور متعددة

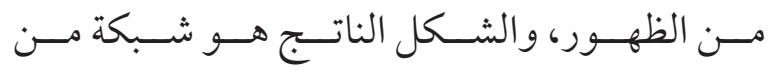

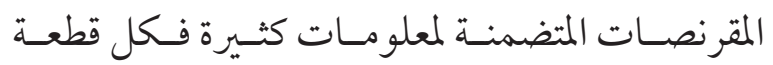
مــن المقرنصـات تحمــل إشـارة (Castera,2006). أمــا

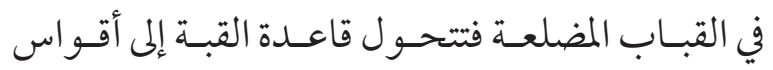

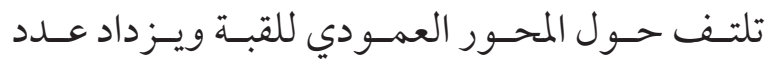

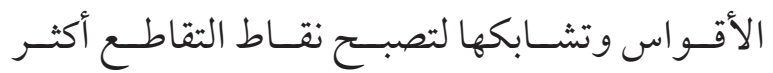

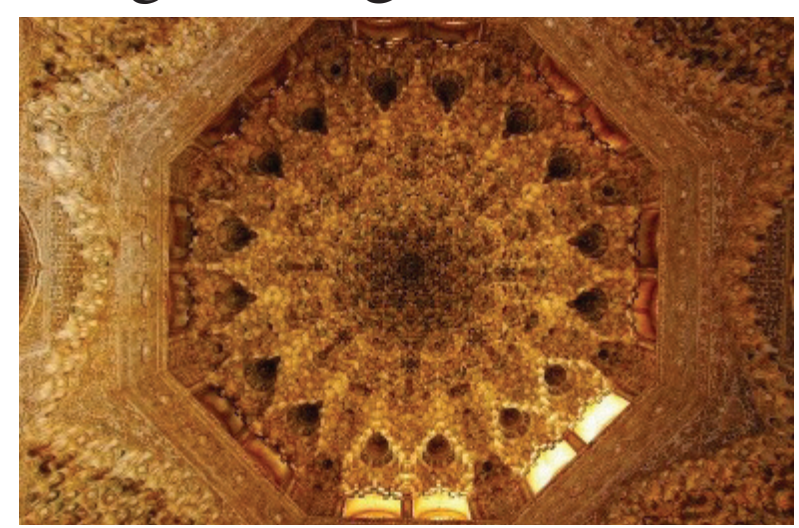

الشكل رقم ( • (). التجزئة الشكلية في قبة قصر الحمراء ومسجد قرطبة، (Castera,2006)، (القحطاني، 9 + . ). 
فالخـط المتعــرج وذو الانحنـاءات هـو عـدد كبـير مـن الخطــوط المســتقيمة، ويمتلـك مســاحة معلو مــات

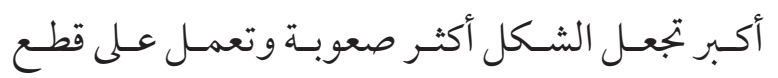

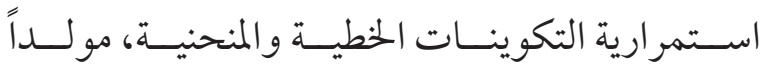

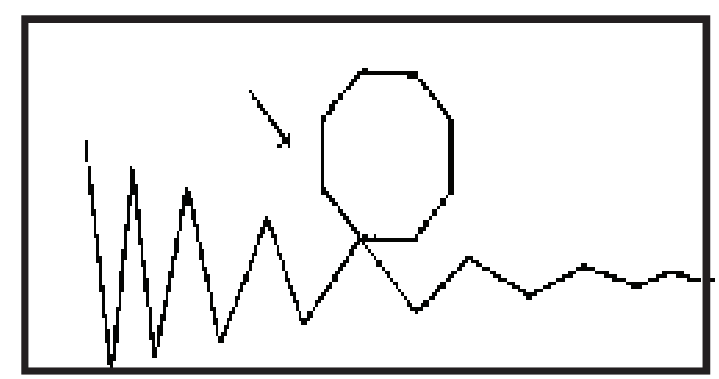

Metzger، الشكل رقم (1 (1). التعرجات تنتج وحدات بزاوية .)(2006
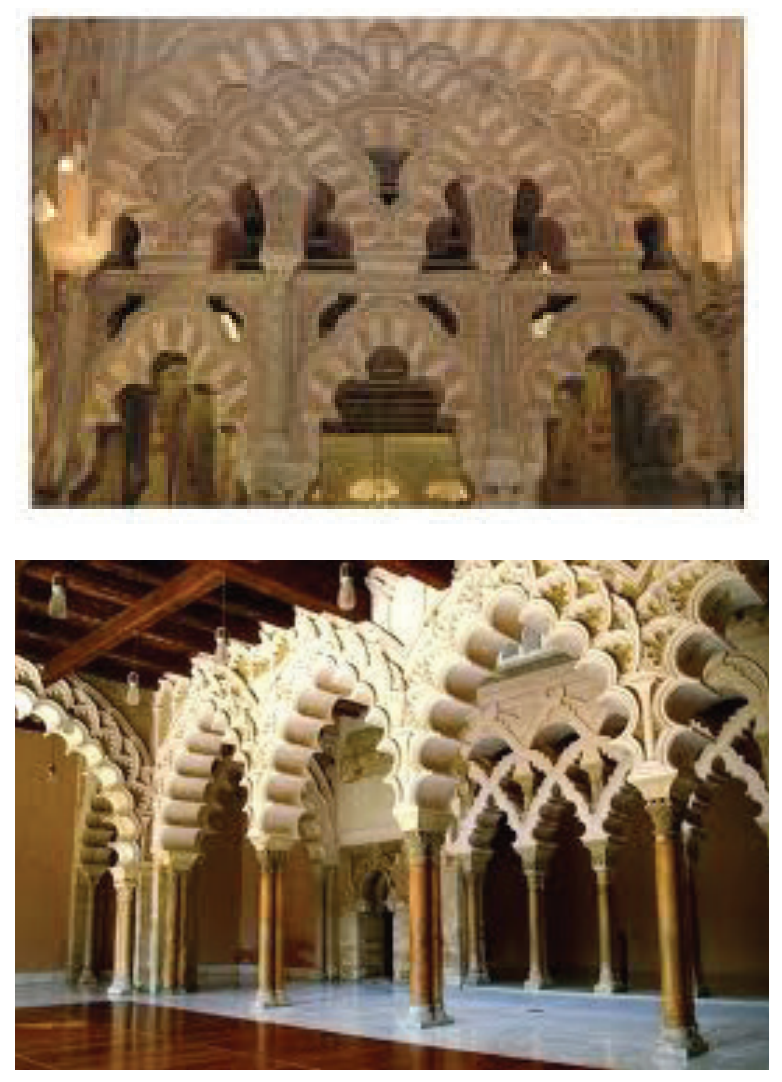

الشكل رقم (Y I ). العقود في مسجد قرطبة وقصر الجعفرية

.(Jo-Tonna, 1990)

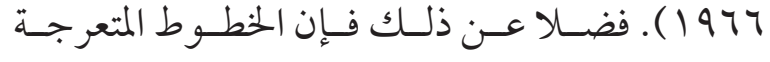
تعمـل عـلى قطـع الاسـتمر ارية للمكونــات الخطيـة

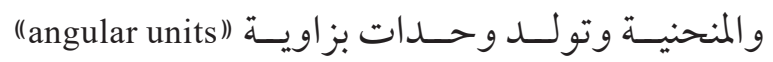
تجعـل الشـكل أكثـر صعوبــة وتقلـل النظـام لتعطـي

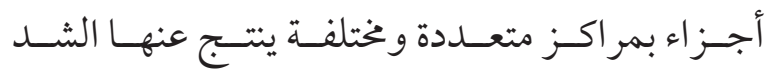

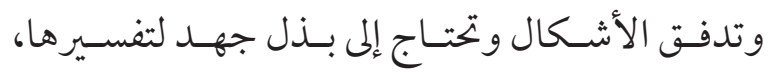
الشـكل (11) (1)، (Metzger,2006). وبيولوجيــاً فــإن الخلايـــا المســتقبلة في الدمـــاغ تتحســس مبـــاشرة إلى الزوايــا والانحنــاءات وانقطــاع اســمرارية الخطــوط Salingaros,2000) . و اتسـمت بعـض أبنيـة العـلمارة الإســلامية باعتــاد التثليـمات أو التســينات ، ((convexities) والتحدبــات (indentations)

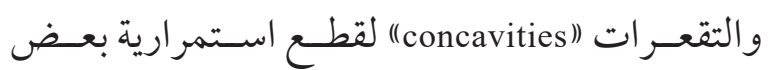

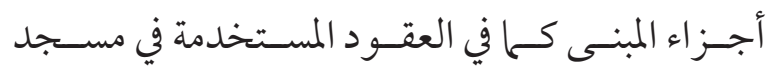

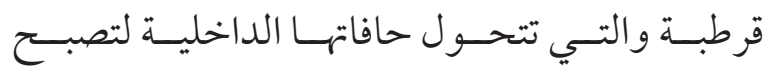

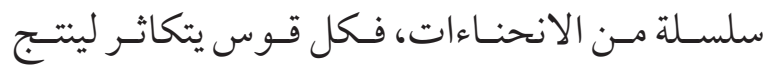

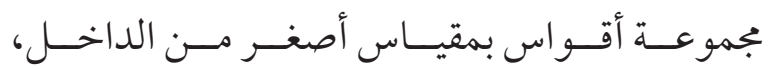

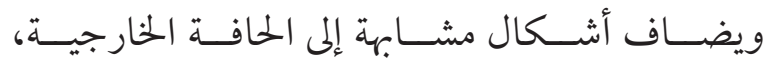

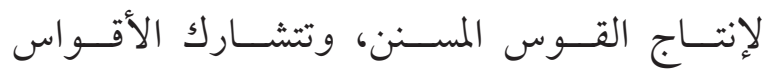
المو جـودة في المبنسى نفـس عمليـة توليـد الشـكل دون

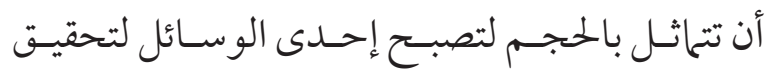

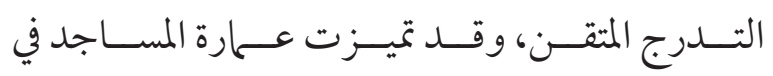

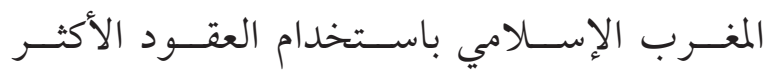

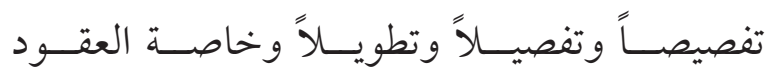

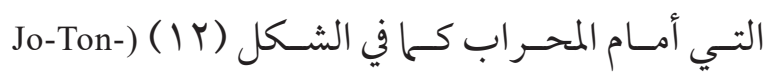
.(na, 1990

يتبـين محا سـبق أن اسـتخدام آليـة الانحناءات و التعرجــات تعـد وسـيلة لتحقيـق الزيــادة الكميـة 


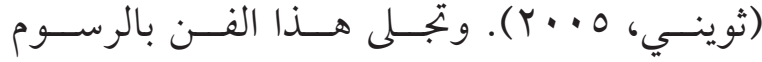

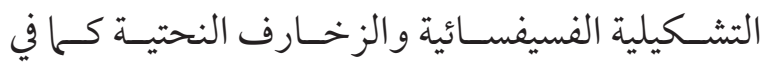

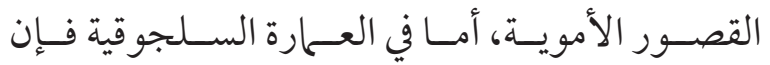

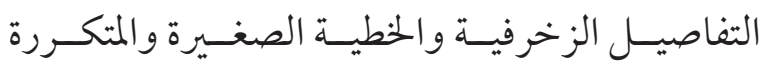

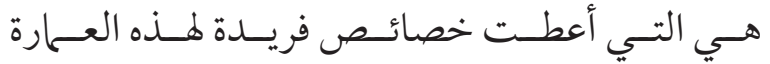

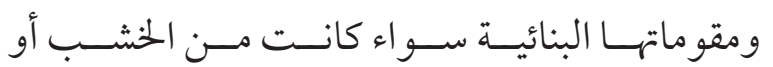

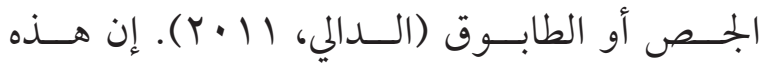

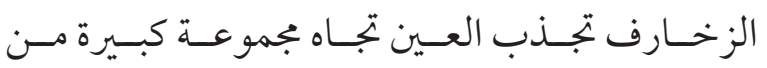

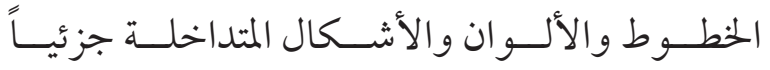
والتـي تعطي فرصسة لوضـع العنـاصر بعضهـا فـوق

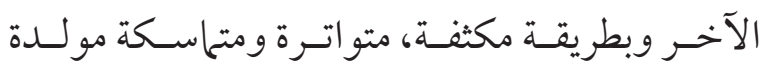

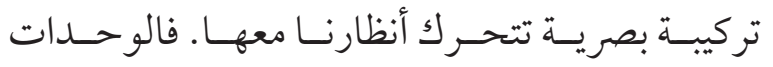

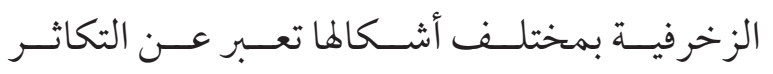
و التعقيـــ مولـدة حركـة مســتمرة ديناميكيـة لتمثـل

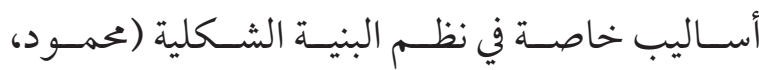

(r.) $r$

يتضــح مــا سـبق ذكـــه أن زيـادة التفاصيـل

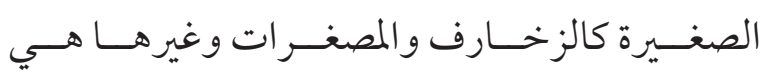

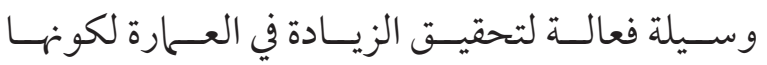

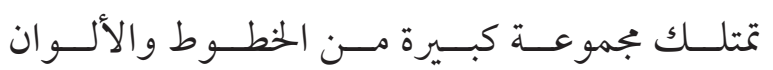
و الأشـكال والعنــاصر المتداخلــة والمتر اكبـة بطريقـة

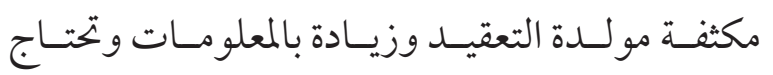
إلى إطالـة النظـر وهـي صفــة ملازمــة لأبنيـة العـلـارة الإســلامية.

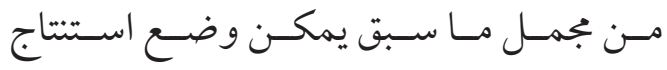

عــام لمســتويات تحقــق الزيــادة الكميــة في ميــــان
وحسـدات إضافيـة بزو ايـا ومر اكـز متعـددة.

ع , r , زيادة التفاصيل الصغيرة:

أشــارت الدراســات اللغويــة إلى تحقيـقت

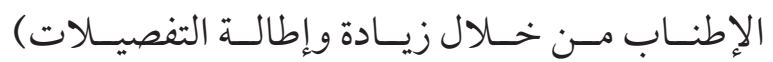

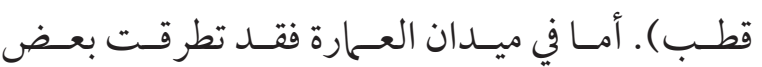

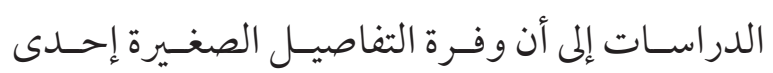

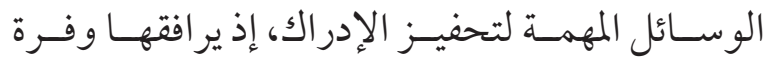

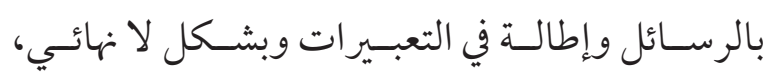
وتعـــ المصغــرات (miniaturization) صغـــة ملازمــة للنـــص الجـــالي وهـــي إحـــــ الأدوات المفتاحيــة

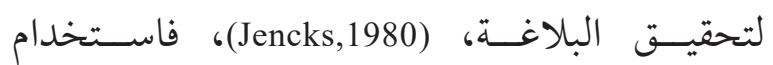

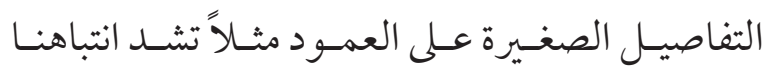

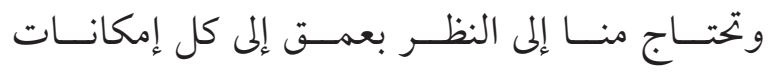
العنــصر وتفاصيـل أجزائـــ (Broadbent,1980).

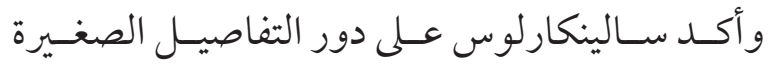

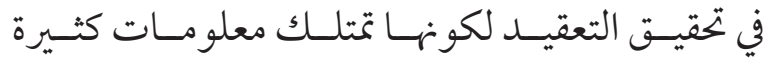

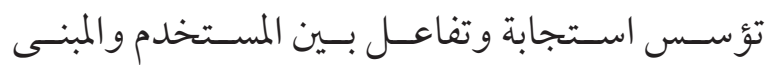

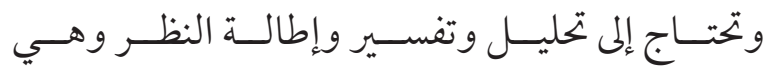
صفــة ملازمسة للأبنيـة التاريخيـة ومنهــا أبنيـة العـلـارة

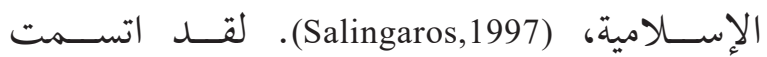
السـطوح و العنـاصر الشـكلية في العـارة الإسـالامية باسـتخدام فـن المصغـرات وهـي نـوع مسن الزخارف

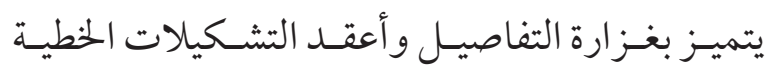

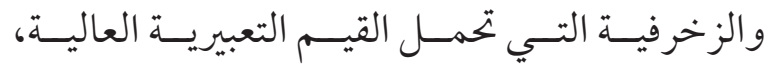
فالمصغــرات: تعنـي الـشيء الصغــير والجميــل

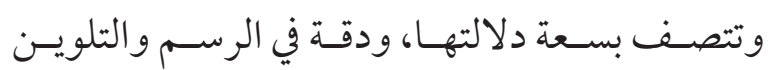




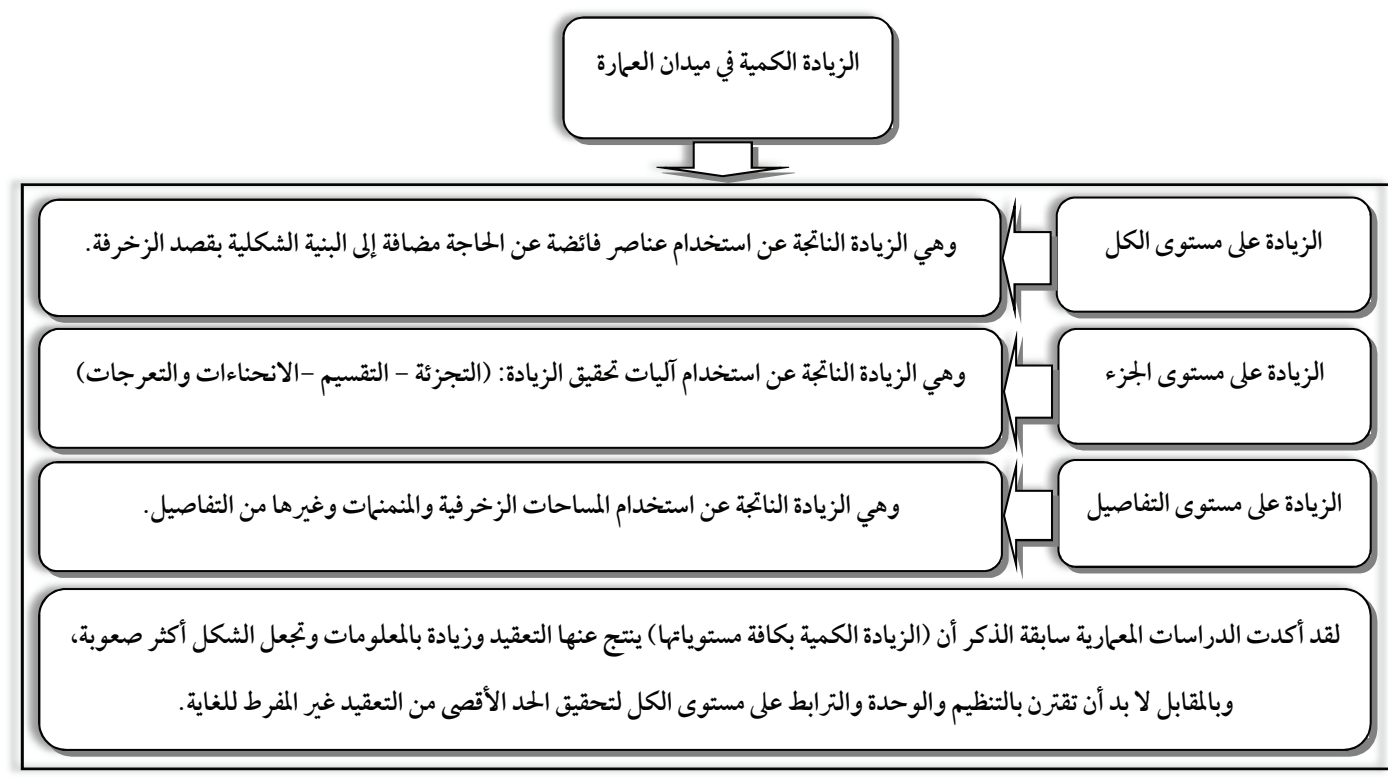

الشكل رقم (r ا ) . يوضح مستويات تحقق الزيادة الكمية في العمارة (إعداد الباحث).

تتكـون مسن سب نموذجــاً شـملت: مســاجد وقصـوراً

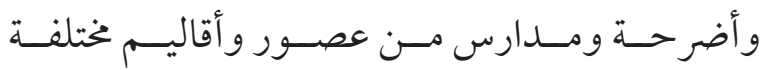

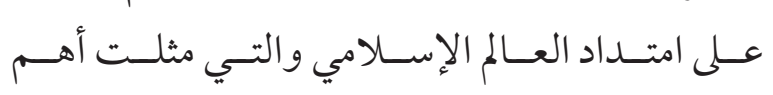

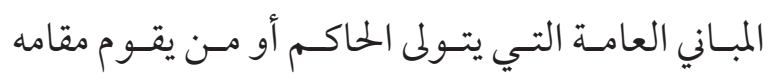

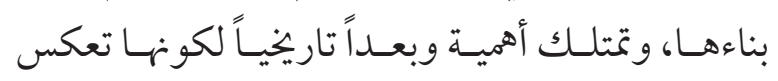

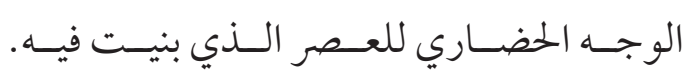

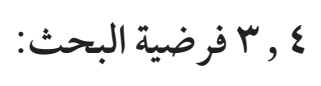

اسـتثمار أسـلوب الإطنـاب البلاغـي في نظـم الواجهــات الداخليــة لأبنيــة العـــارة الإســلامية

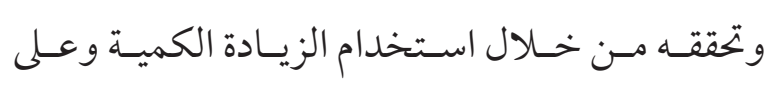
المســتويات كافــة: الـكل، والجـــــ، و التفاصيـل الصغـــرة وبدرجــات متفاوتــة عــبر العصــور و الأقاليـم المختلفــة، فعـلى مســتوى الـكل : تتبايسن

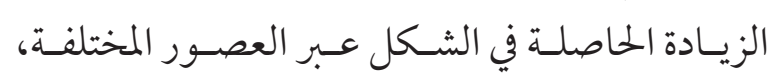
ويتميـز بعـــ العصــور أكثـر مــن غيرهــا بالتركيـز
العـــارة كــا في الشــكل (س ا ).

r ر ب وضــع حـــدود للدر اسـة العمليـة واعتبــارات

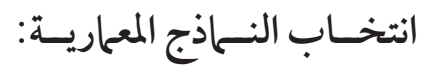

إن أهـــم الخصائُصـ الشــكلية في العــارة

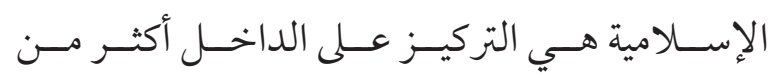

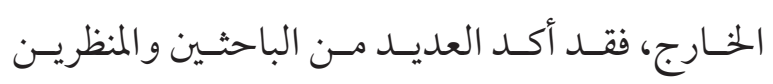

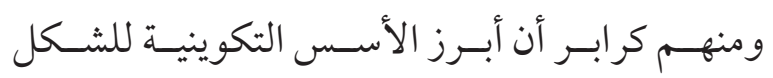

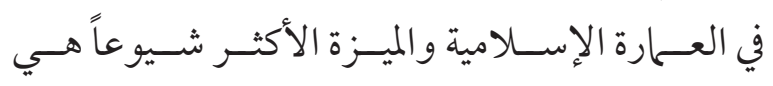

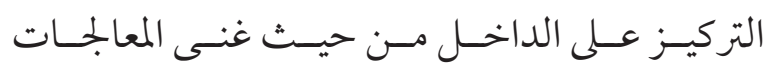

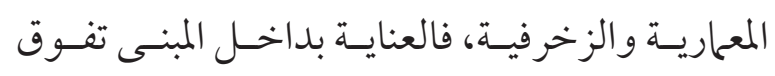

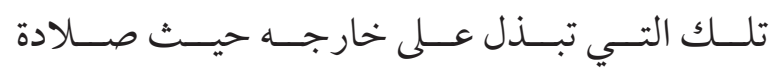

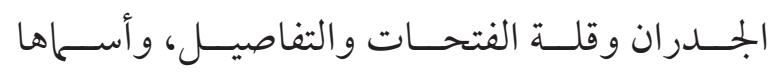
بالعـــارة المسـتترة، (Grabar,1975)، (Hoag,1978).

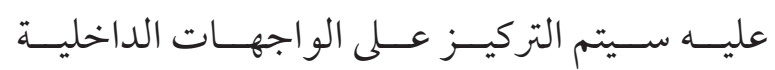
وليـس الخارجيـة، وسـيتم انتخــاب عينـة شـمولية 


\section{( ) 1 , 1 ع الزيادة على مستوى الكل:}

تمــت الإشــارة إلى إمكانيــة حســـاب مقــــار

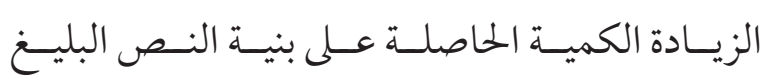

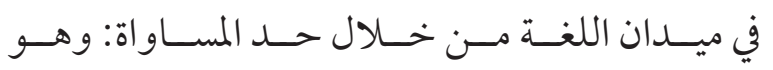

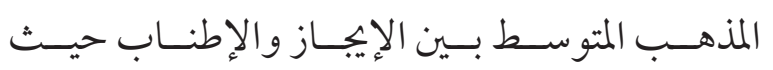

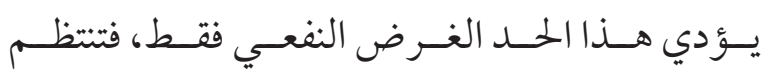

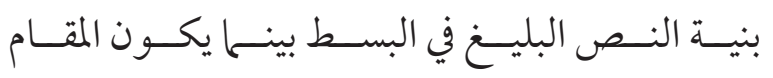

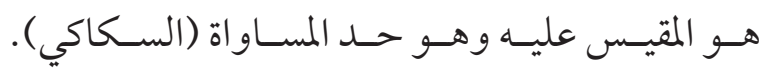

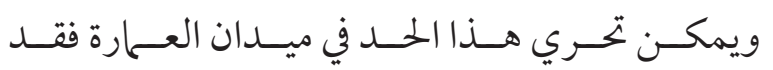

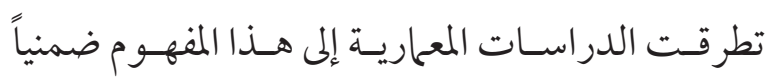

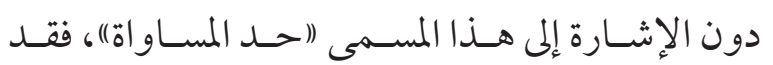

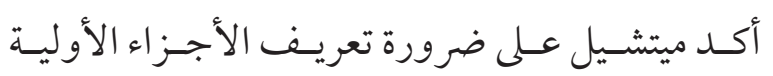

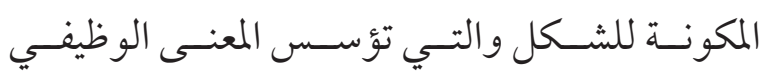

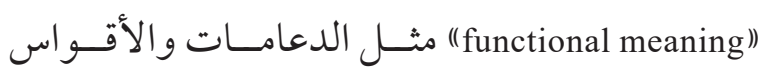

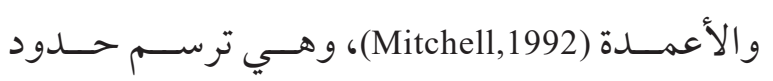
البنيــة وتعتـبر ذات أهميـة لكـــ نون الفكــ يحتـاج إلى قيم

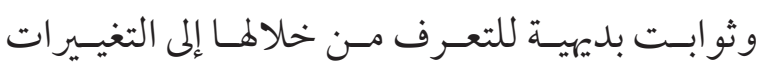

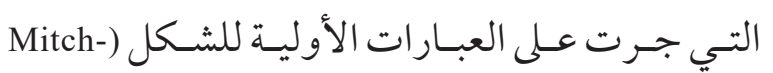
.(ell,1992

نسـتنتج مــا سـبق أنسه يمكـن تثيــت حسـ

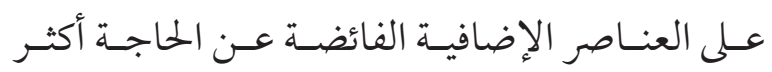

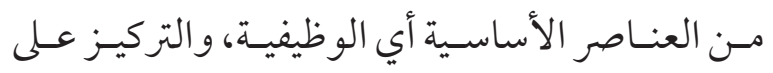

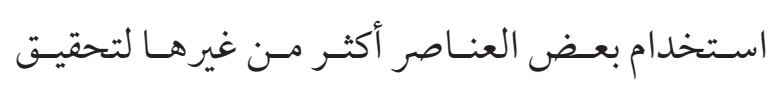

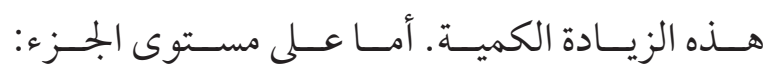

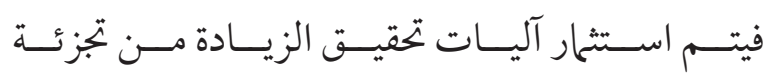

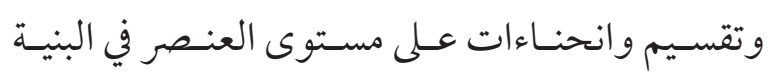

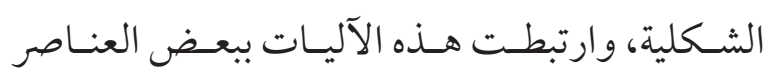

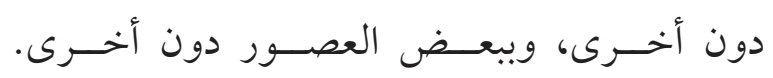

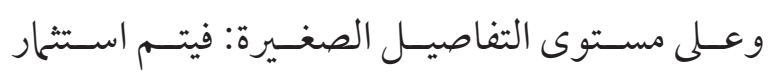

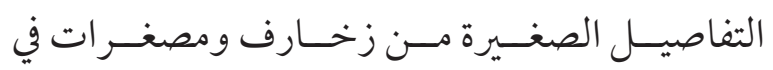

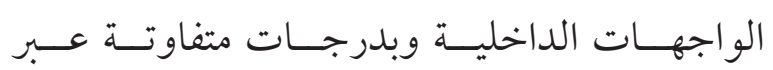

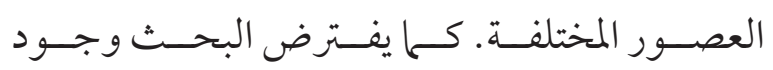

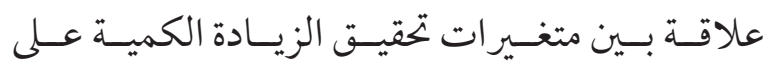

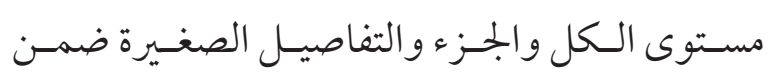

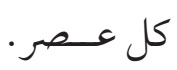

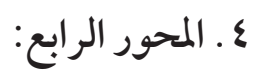
| 1 سـيتم تحليـل الزيـادة ضمــن كافـة مسـتوياتها وكـا يسلي:

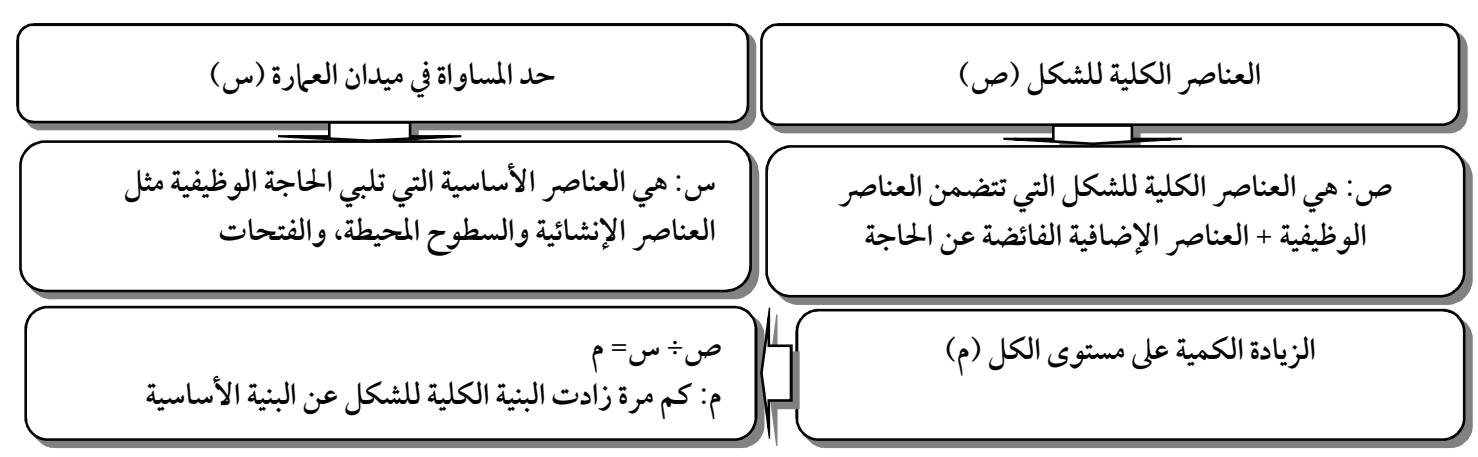

الشكل رقم (\& ) ). حساب الزيادة الكمية رياضياً (إعداد الباحث). 
كذلـك سـيتم اعتـاد وحسـدة افتراضيـة قيمتهــا

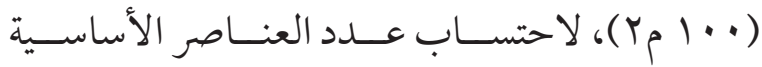
الموجـــودة في هــــه الوحـــــة الافتراضيــة، وعـــدد

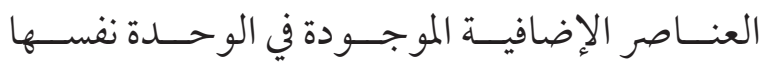

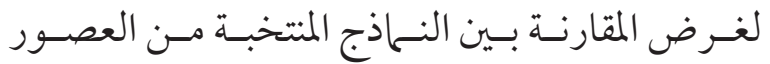
المختلفـة مـن حيـث اسـتخدام كل مـن هـذه العناصر

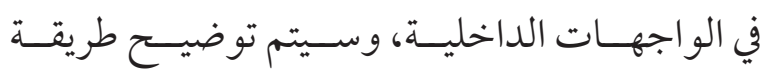
القيـاس بالتفصيـل كـا يـلي: عـدد العنــاصر الأساسـية (س) ) المســاحة

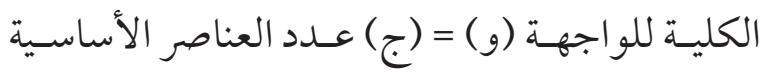

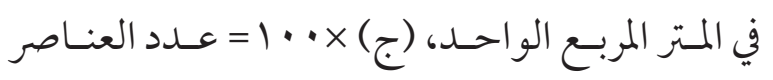
الأساسـية في · · ا مr . و كذلـك سـيتم احتسـاب: عـدد العنــاصر الإضافيـة (ز) ثـ المســاحة

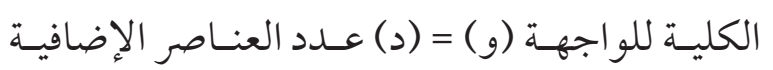

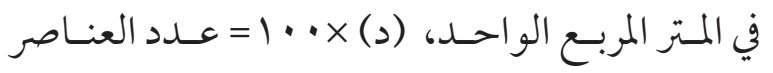

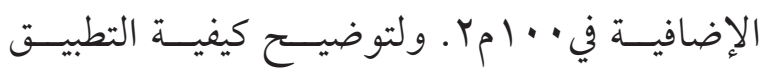

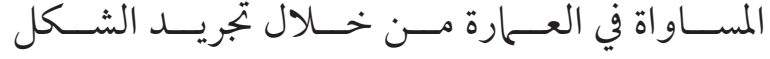
إلى عنــاصره الوظيفيــة الأساســية وفــت المبـادئ الطبيعيـة للتـوازن، وتفســـر كيفيـة رسـوخ الشــكل وفـتق الارتباطـات الموضوعيـة للبنيـة، ومــن خـالال

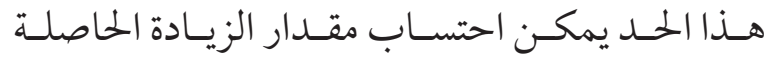
باسـتخدام العنـاصر الإضافيـة الفائضـة عـن الحاجة، وكــا في الشــكل (ع ا ). ولحســاب (م) وهـــي مقــدار الزيــادة عـلى مستوى الـكل: سـيقوم الباحسث برسـم الواجهــات

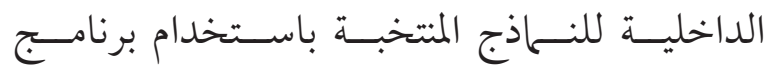
الأوتـو كاد بمقيـاس رسـم وتحديد العناصر الأساسـية

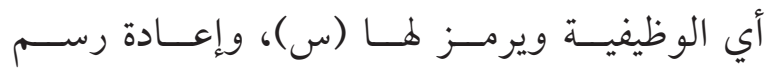
الواجهــات بعناصرهـــا الكليـة المتضمنــة للعنــاصر الوظيفيـة و الإضافيـة (الفائضسـة عـن الحاجـة) ويرمـز

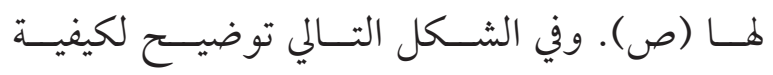

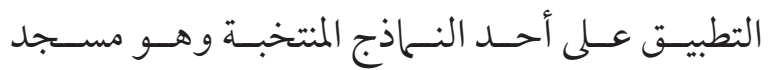

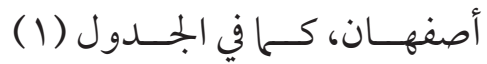
جدول رقم (1) . يوضح عدد مرات الزيادة في النموذج (مسجد أصفهان) .

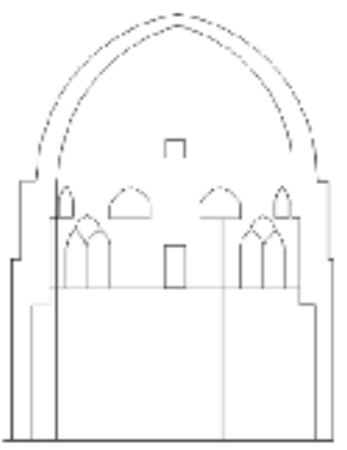

عدد العناصر الاساسية (س) = ع اعنصر

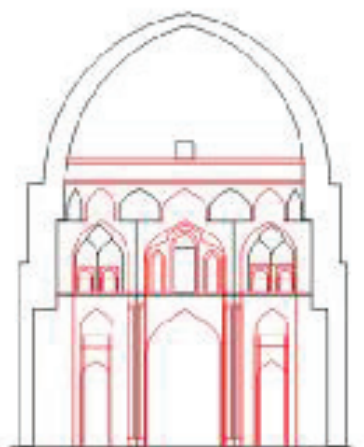

عدد العناصر الكلية (ص) = 9ه عنصر

$$
\varepsilon, Y=1 \varepsilon \div 09 \quad \rho=0
$$

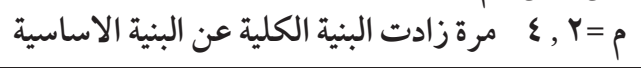


جدول رقم (Y). حساب عدد العناصر الوظيفية والإضافية والكلية في الوحدة الافتراضية في مسجد أصفهان (إعداد الباحث).

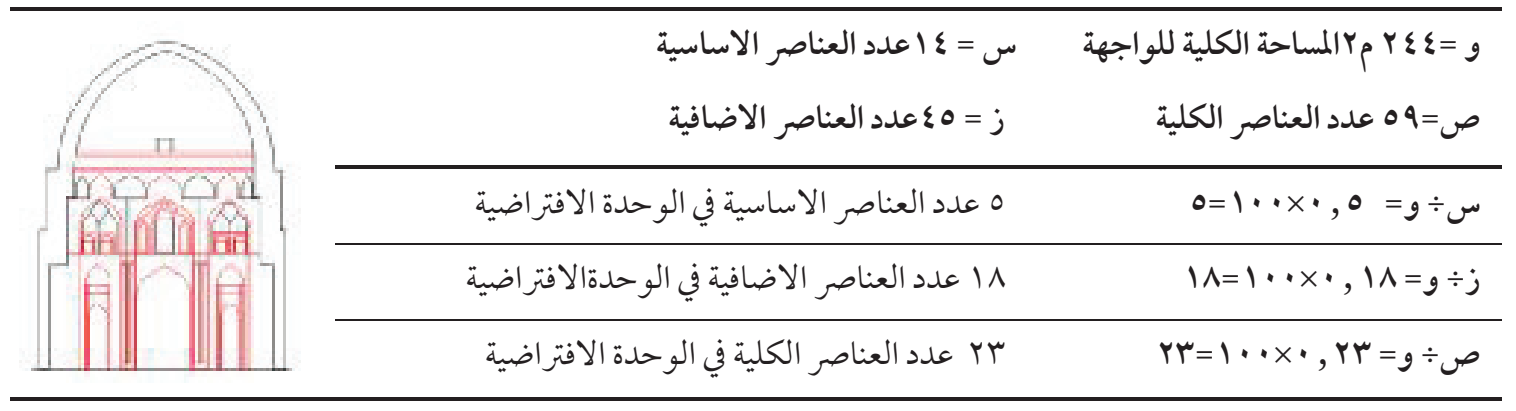

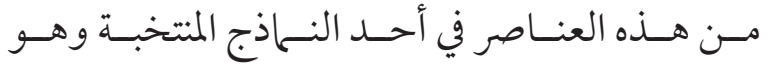

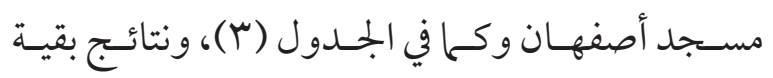

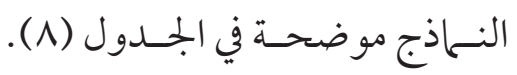

ب

سـيتم التحليـل ل الوصفــي واسـتقراء

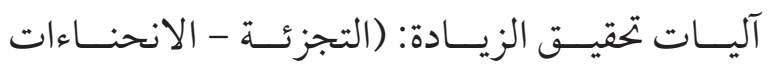

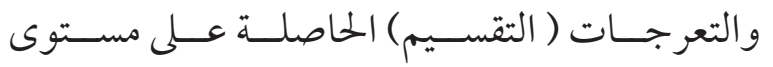
كل عنـصر مـن العنـاصر الموجـودة في الشـكل وهـي

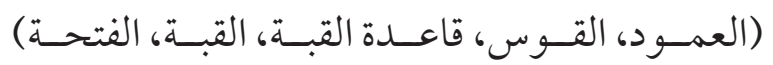

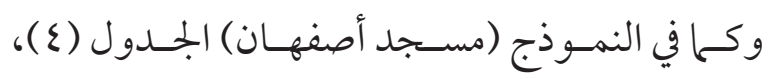

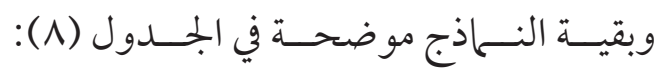

ץ, 1 , ع الزيادة على مستوى التفاصيل الصغيرة: جدول رقم (r). نسبة استخدام كل عنصر في واجهة مسجد أصفهان (إعداد الباحث)
سـيتم احتسـاب عـدد العنـاصر الوظيفيـة والإضافيـة

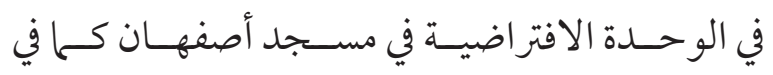

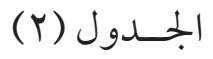

كـا سـيتم تحديد نسـبة اسـتخدام كل نـوع من أنـــواع العنــاصر الإضافيـة التـي اسـتثمرت لتحقيـق

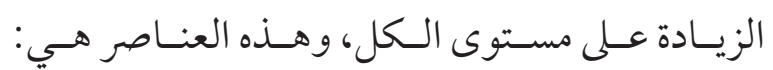
(القـوس و العمــود و الحليـة و الأحز مــة) و التي تبايسن اسـتثمارها ضمــن البنيـة الإضافيـة، وسـيتم حســابها كــا يـلي: حاصـل قسـمة عـدد كل نـوع مـن هــذه

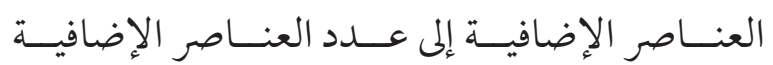

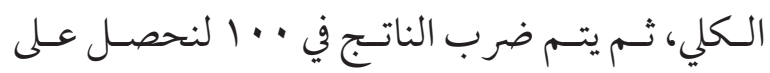

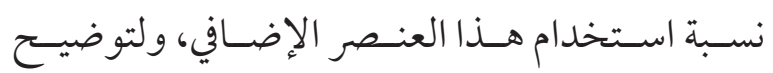
كيفيـة التطبيـق سـيتم احتسـاب نسـب اسـتخدام كل

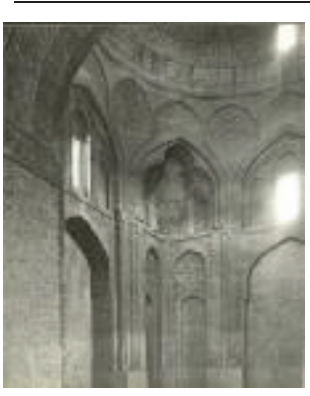

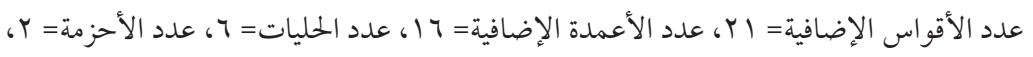

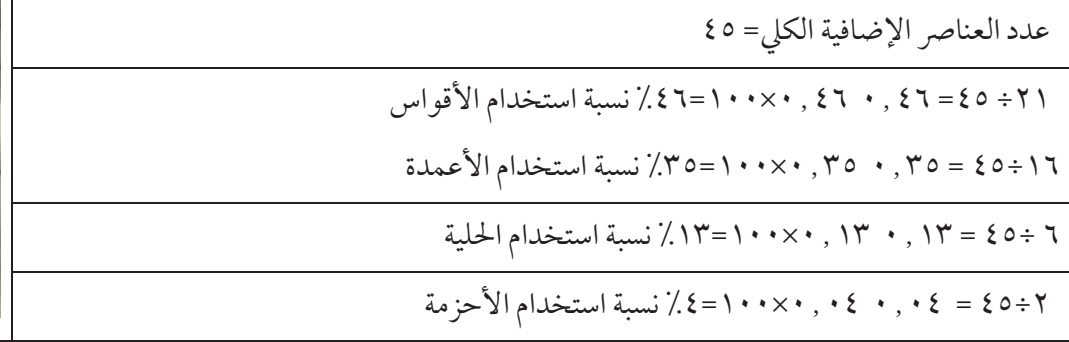


جدول رقم (ع ). آليات تحقيق الزيادة الحاصلة على العنصر في مسجد أصفهان (إعداد الباحث).
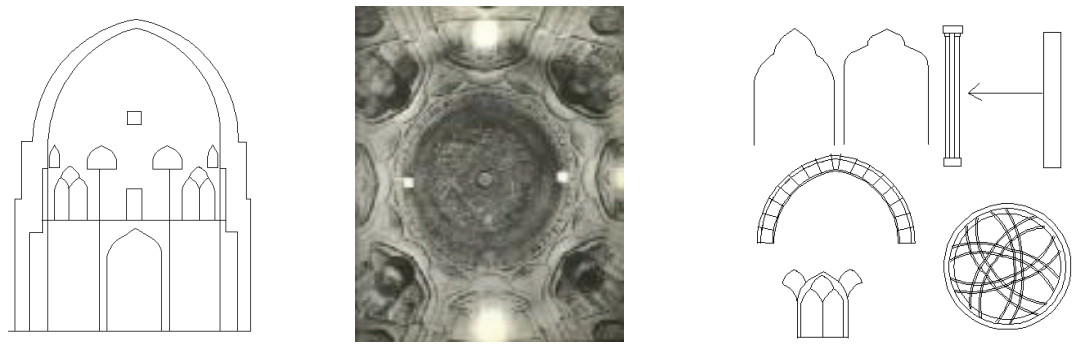

الواجهة الداخلية

منظور داخلي للعناصر المعحارية

آليات التجزئة والتقسيم والانحناءات في العناصر

اختبــار دنكــن متعــدد المــدى، إذ ميـزت المعامـلات

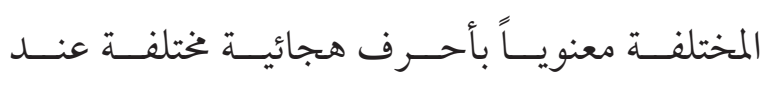

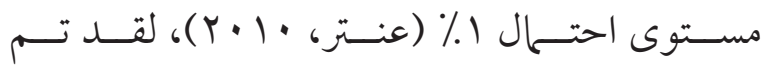

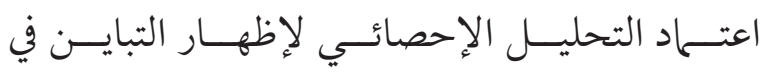
معـدل تحقيـق الزيـادة الكميـة بكافـة مسـتوياتها عـبر

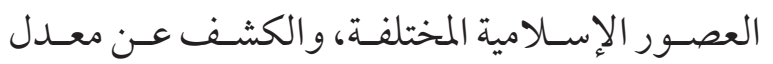

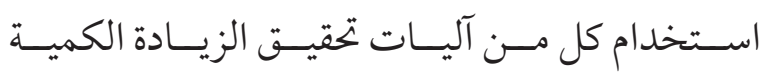

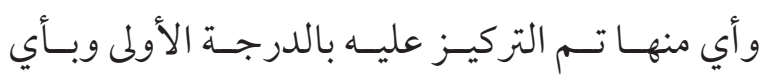
مـن العصـور و العنـاصر ارتبطــته، وهـي موضحسة

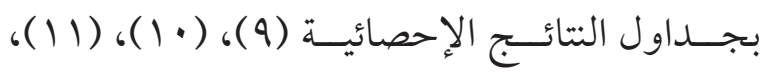
(I乏)، (IY)، (IY) ع , ع النتائج والاستنتاجات: أظهــرت نتائسج تحليــل مقــدار الزيــادة عـلى

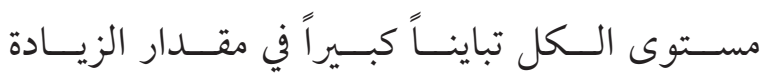

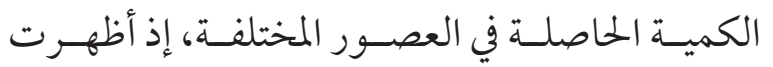

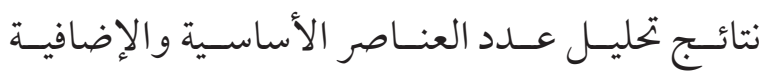

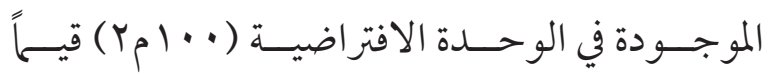

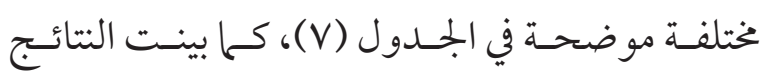

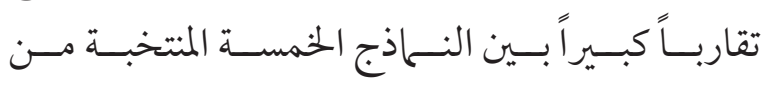

سـيتم احتســاب نسـبة التفاصيـل الصغـيرة في

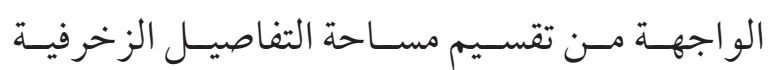

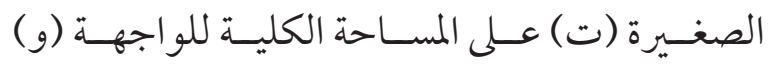
بالاعتـــاد عـلى الصـــور التوضيحيــة، وذلــك يتـــم رياضيـاً كــا يـلي:

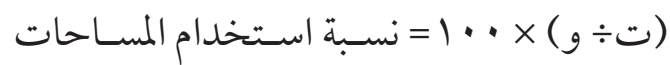

الزخرفيــة ضمــن المســاحة الكليـة للو اجهــة، كـــا موضــح في الجــدول رقـمم (1). ب النحاذج المنتخبة: النــاذج المنتخبـة مـــن العصــور الإســامية

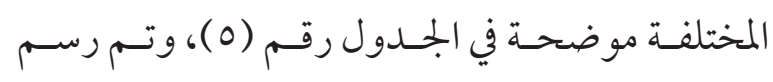

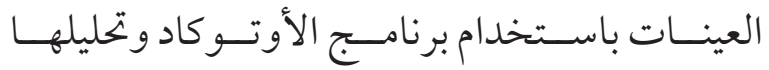
وفـتق وســائل القيــاس التـي تـــم إعدادهـــا مســبقاً،

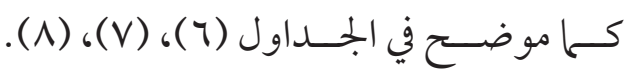
r ع ع التحليل الإحصائي: ســيتم تحليـل البيانــات الناتجــة وفــق نظــام التجــارب البسـيطة باسـتخدام التصميـم العشــــئي

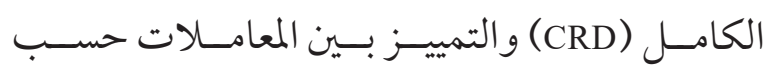




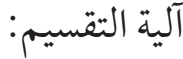

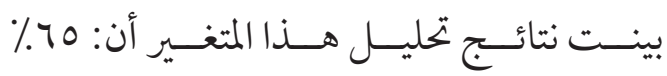

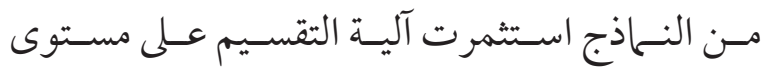

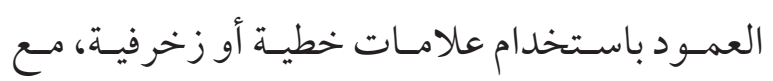

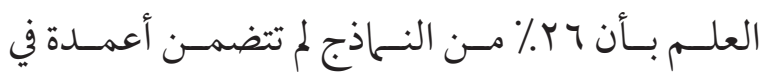

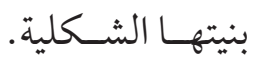

• 9\% مـن النــاذج المنتخبــة اسـتثمرت هـــهـ الآليــة عـلى مســتوى القــوس وذلــك باسـتخـدام

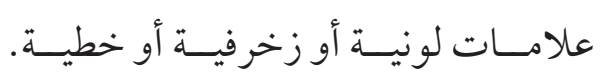
ب \% مـن النـاذج اسـتثمرت آليـة التقسـيم

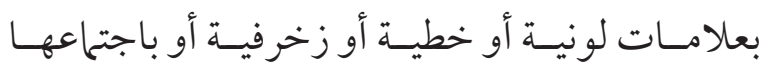
معـاً في قاعـدة القبــة.

\% \% مــن النــاذج المنتخبـة اسـتخدمت

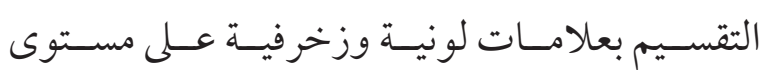

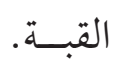

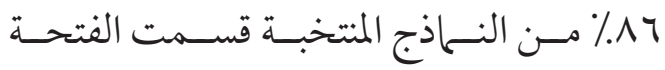

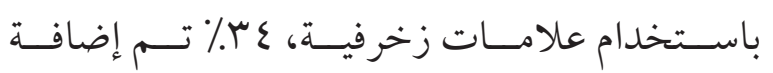

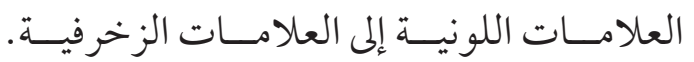

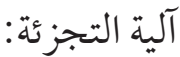

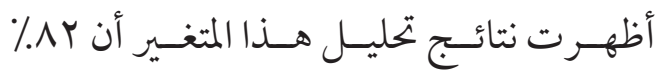

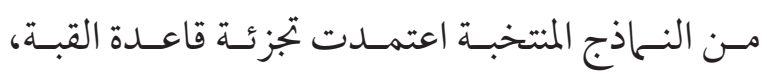

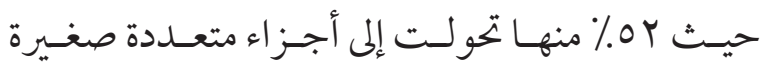

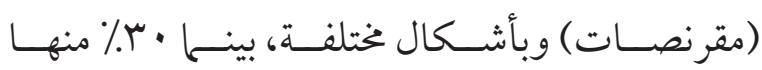

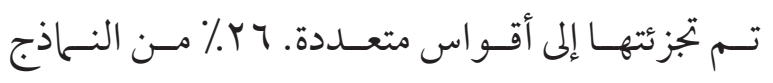

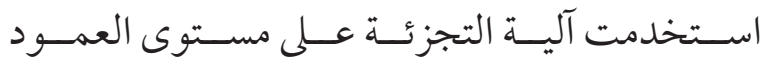

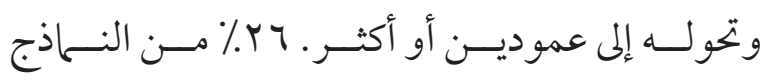

العـصر العثلماني مسن حيـث عـدد العنـاصر الإضافيـة

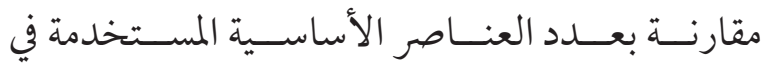

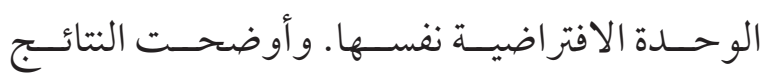

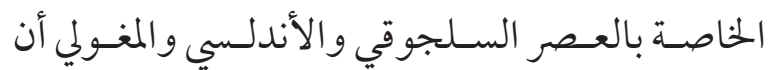

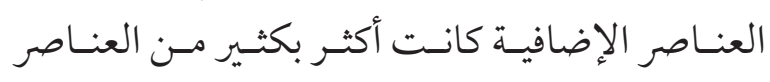

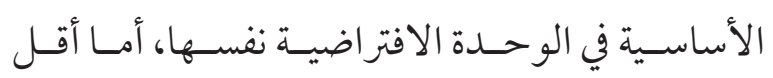

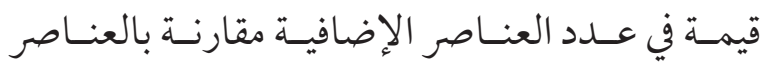

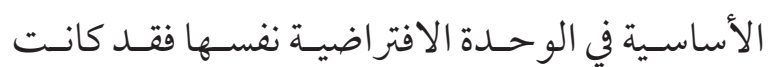
في العـصر الفاطمسي.

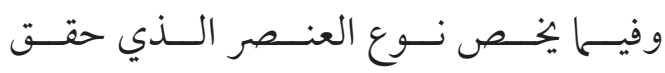

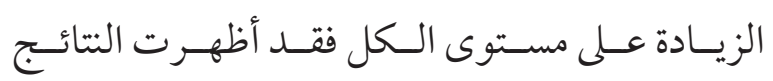

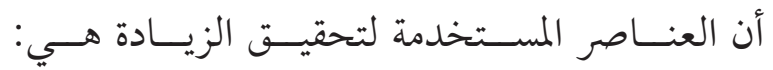

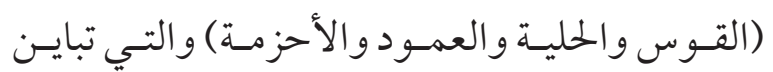

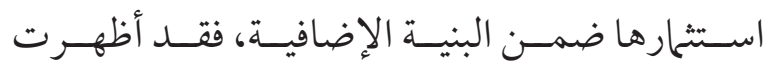

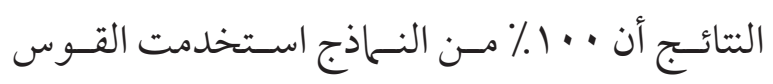

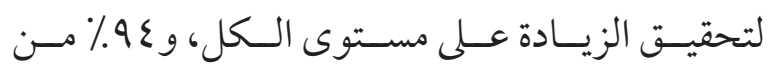
النـاذج اسـتخدمت الحليــة لتحقيـق الزيـادة، بينــا

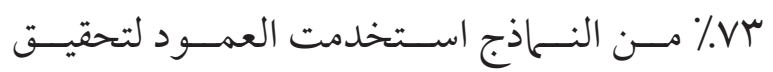

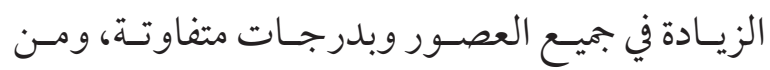

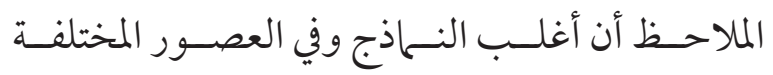

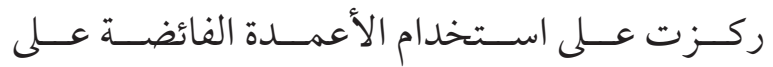

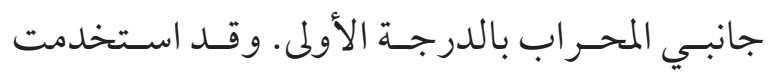

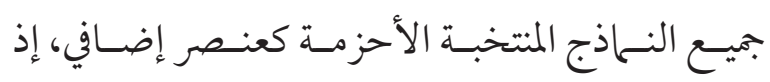

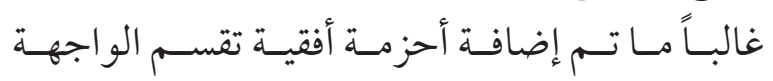

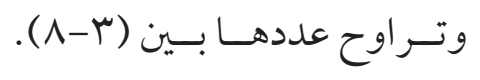

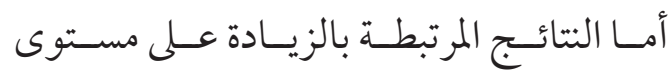

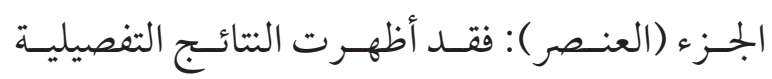

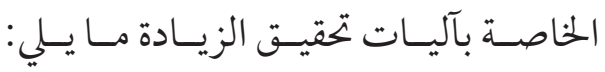




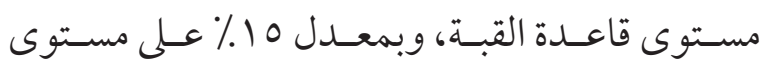

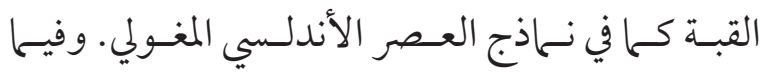

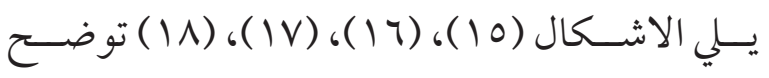

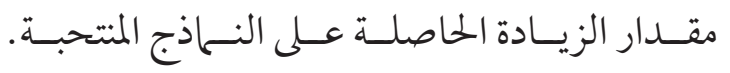
0, ـ الاستنتاجات:

( مـ 1

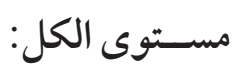
تسم إثبـات فرضية البحــث في استختدام الزيادة

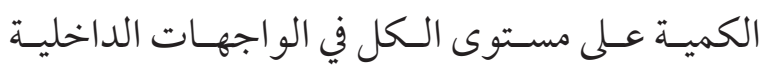

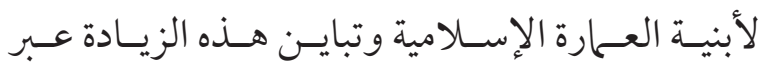

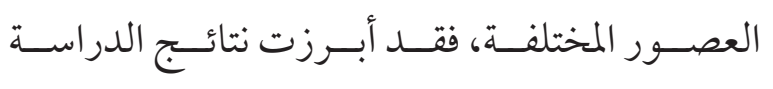

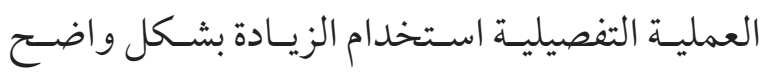

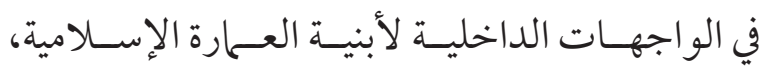

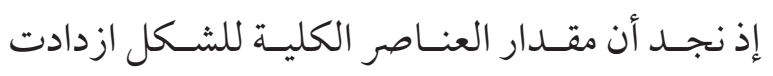

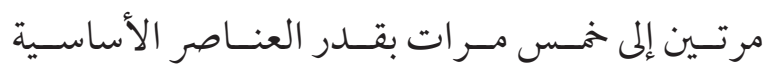

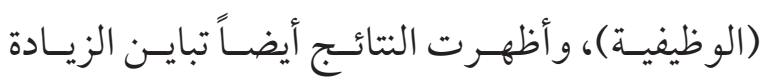

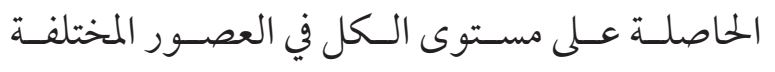

اسـتخدمت هـــه الآليـة على مسـتوى القـوس حيث

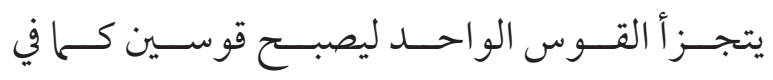

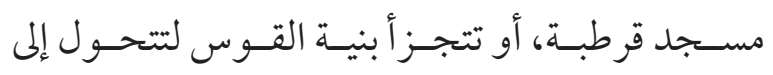

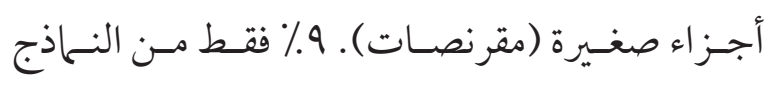

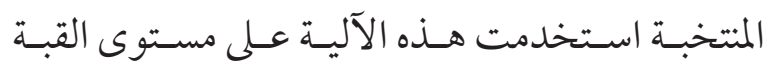
وذلـك في العـصـر الأندلـسي والمغــولي. مآلية الانحناءات والتعرجات: أظهــرت نتائسج تحليـل هـــا المتغــير أن:

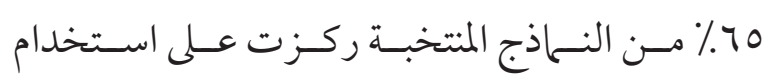

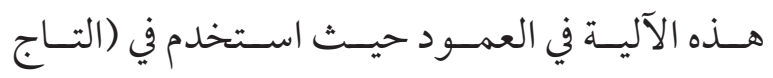

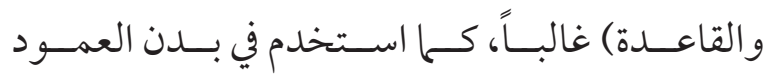

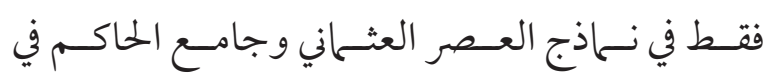

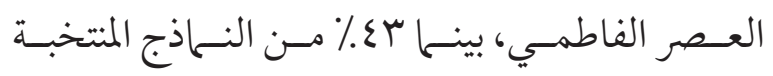

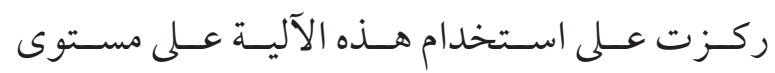

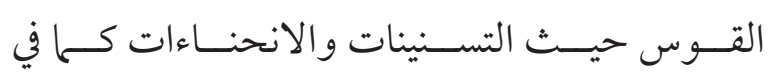

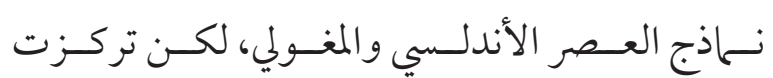

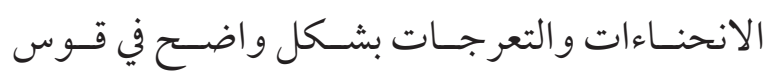

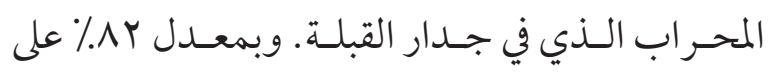

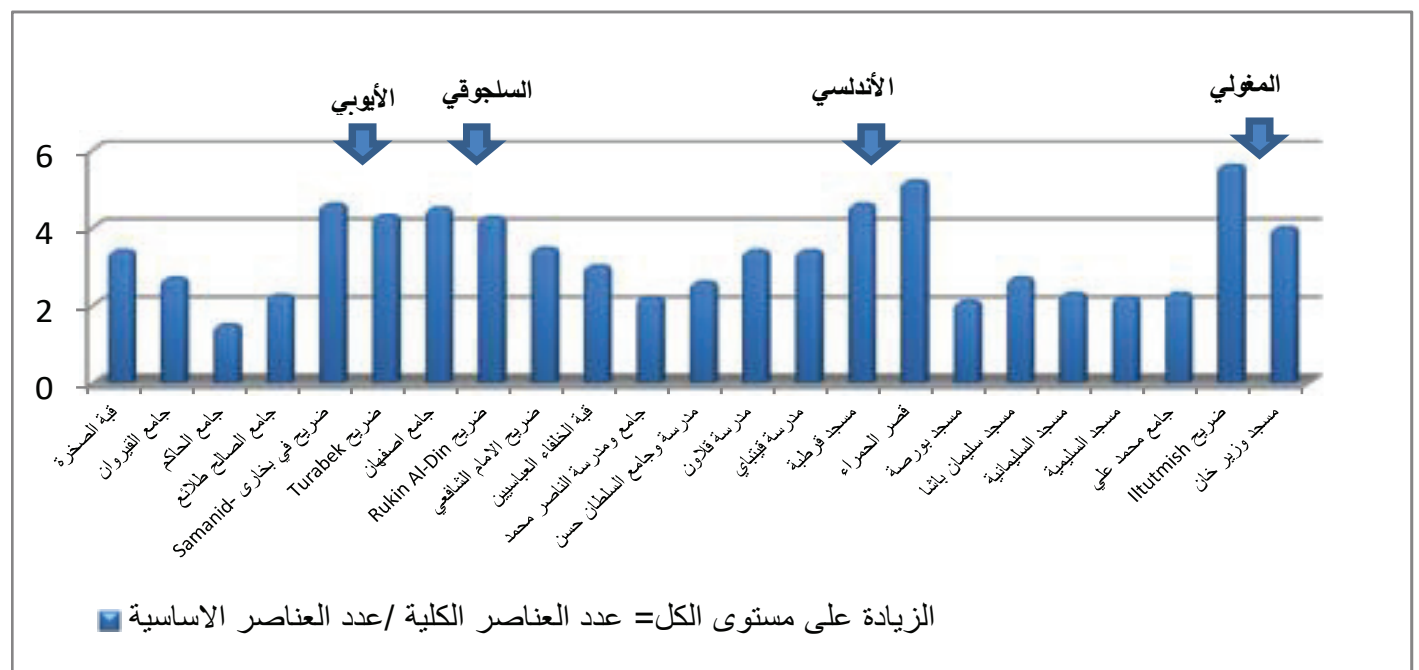

الشكل رقم (10) يوضح مقدار الزيادة الكمية على مستوى الكل عبر العصور المختلفة. 


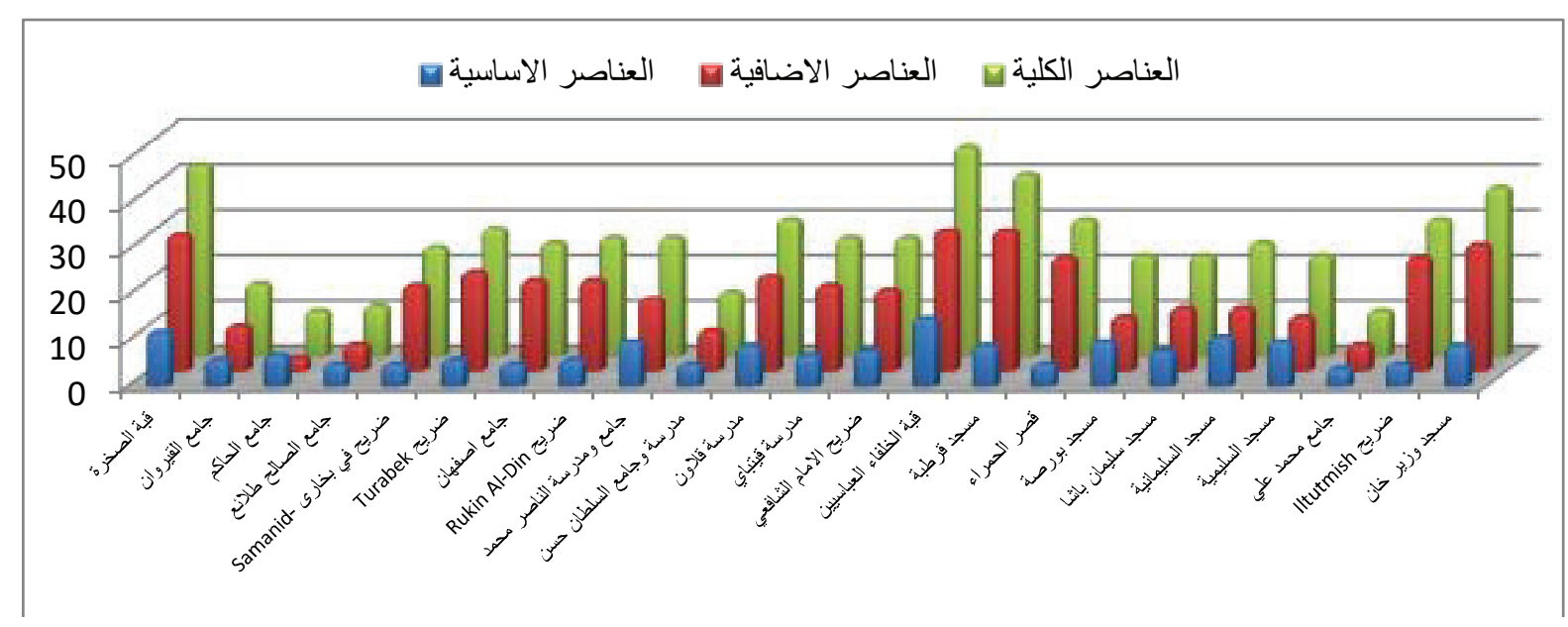

الشكل رقم (7 1 ) . يوضح نسبة العناصر الأساسية والإضافية والكلية في النهاذج المنتخبة.

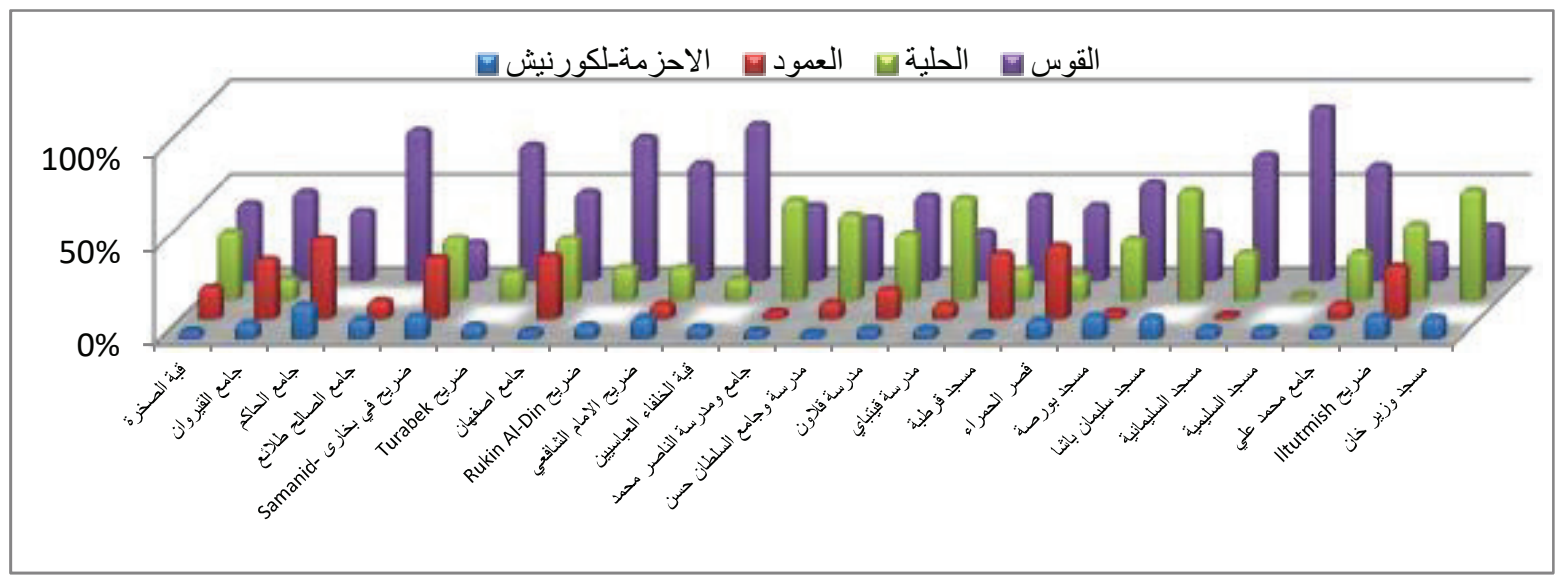

الشكل رقم (IV) . يوضح نسبة استخدام كل نوع من العناصر الإضافية من العناصر الإضافية الكلية.

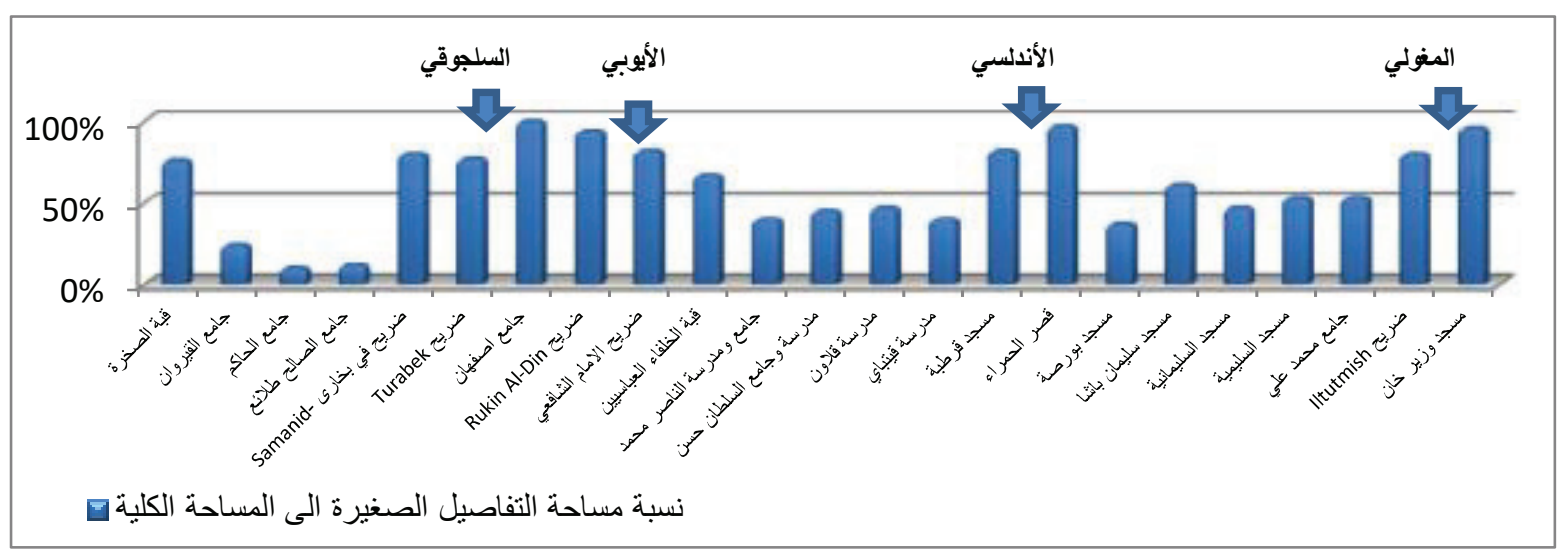

الشكل رقم (11) . يوضح نسبة استخدام التفاصيل الصغيرة إلى المساحة الكلية. 
لتحقـق التعقيــد الممتـع مـن خـالال أسـلوب المعالجـة و القــرار ات المتعلقـة باسـتخدام آليـات تحقيـق الزيـادة مـن (تقسـيم وتجزئسة وانحنـاءات وتعرجـات) و التي

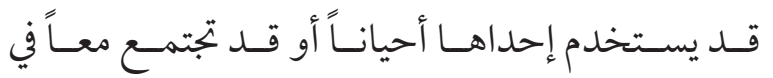

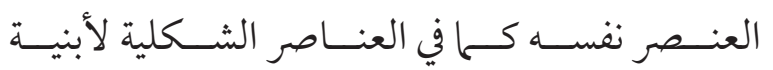

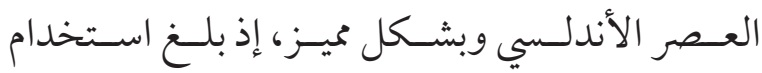

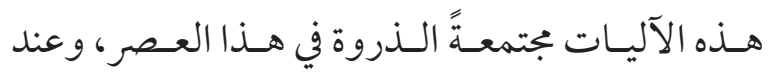
التحليـل الإحصائسي لمعـدل تحقـق كل آليـات الزيـادة

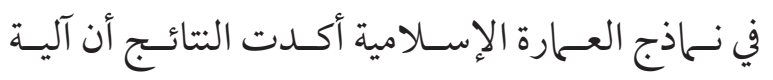
التقسـيم تعــد أكثــ الآليـات التـي سـاد اسـتخدامها

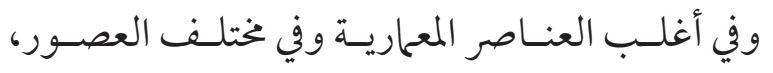

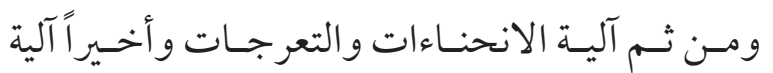

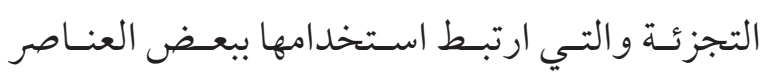

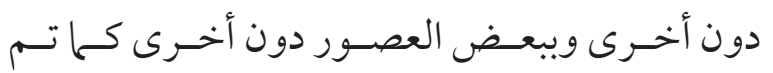
تو ضيحــه فيـا سـبق.

ץ, ه , ع الاسـتنتاجات الخاصسة بالزيـادة الكميـة عـلى مسـتوى التفاصيـل الزخرفيـة الصغـــرة:

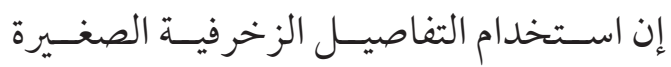

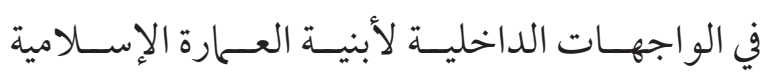
تعــد آليـة أساسـية وفعالـة في نظــم بنيتهــا الشـكلية

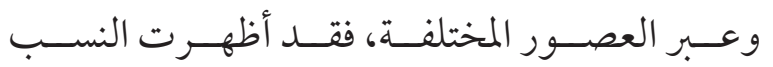
المسـتخلصة مــدى اهتـام المعـلمار المســلم باسـتخدام

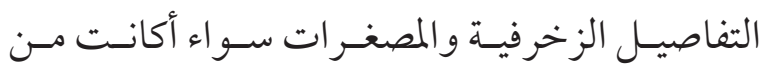

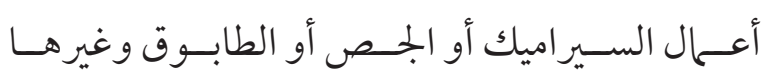

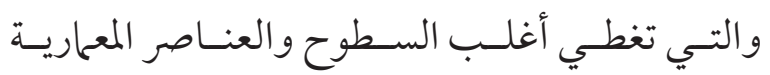
مــن أقــو اس وأعمــدة وقبـابـ، فضــلاً عــن أعــال

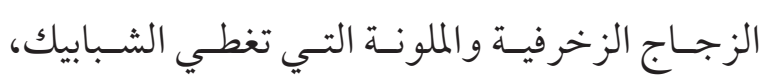

إذ بــــ مقــدار الزيــادة الـــروة في العـــر الأندلـسي

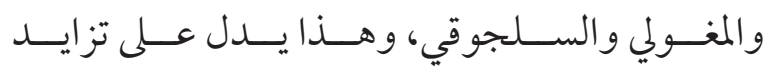

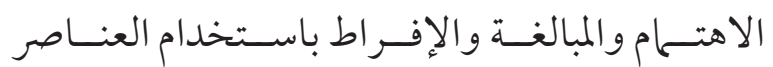

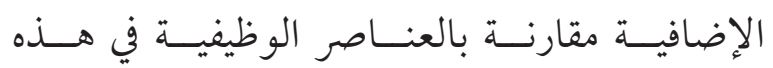

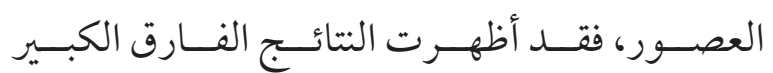

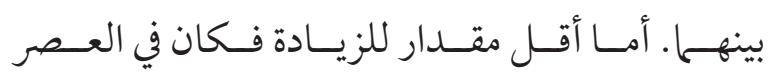

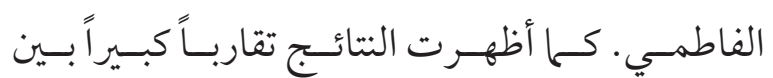

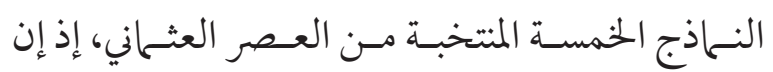

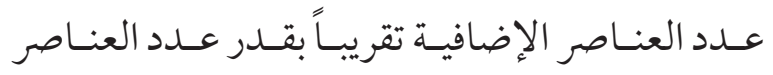

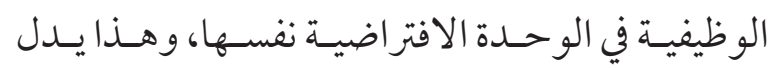

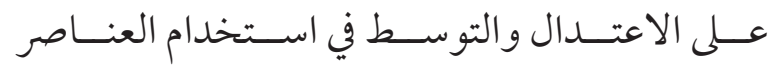

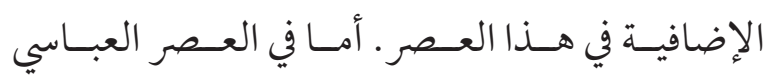

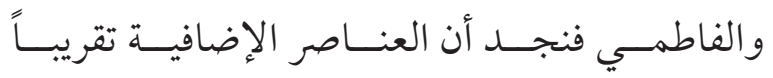

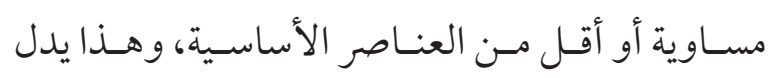
عـلى التركيـز عـلى الناحيـة الوظيفيـة بشـكل واضـح

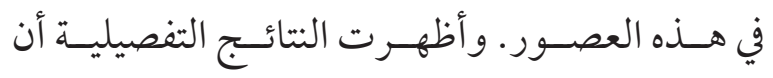

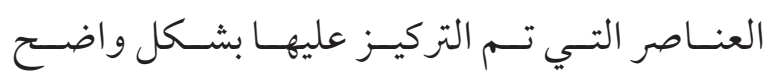

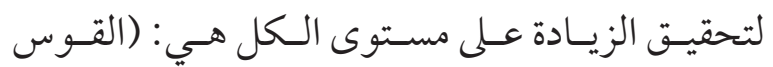

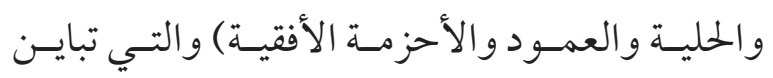

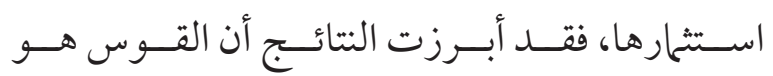

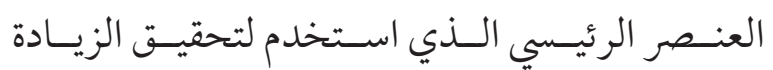

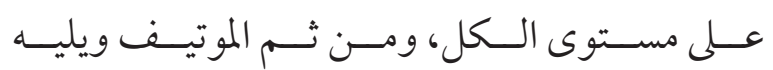

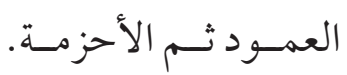

Y , 0 , ع الاسـتنتاجات الخاصـة بالزيـادة الكميـة عسلى مستـتوى الجزءء: إن العنــاصر الشـكلية في العــارة الإســلامية

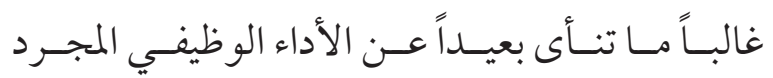


العنــاصر الأساسـية المكونسـة للشــكل، ورافقهـا

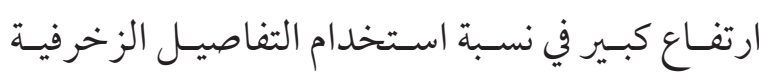

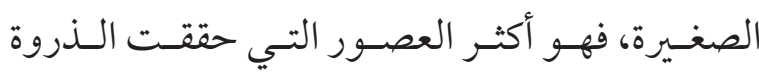

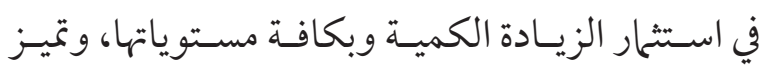

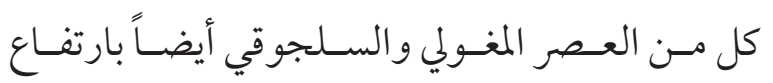

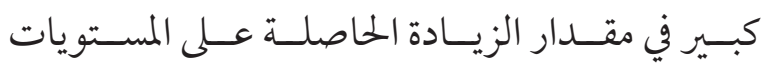

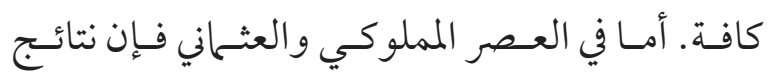

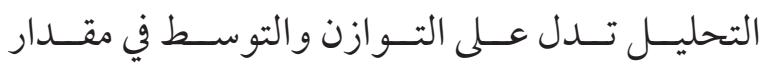

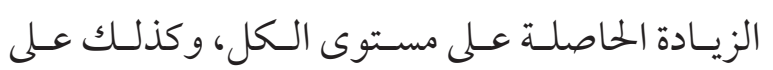

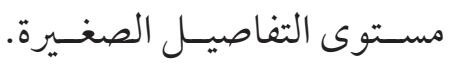
؟ , , , ع استنتاج عام: إن الشـكل في العـارة الإسـلامية ليسس بجـــد

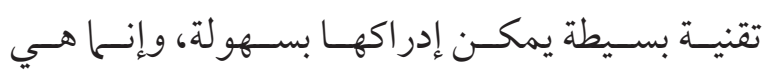

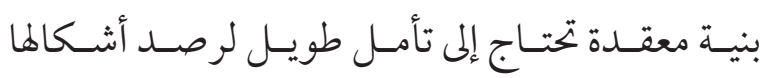

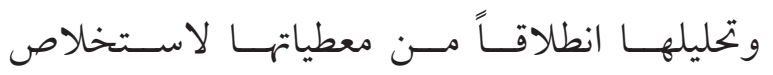

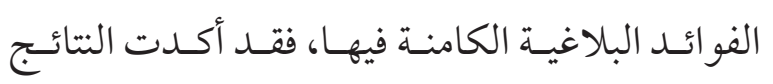

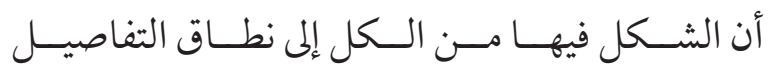

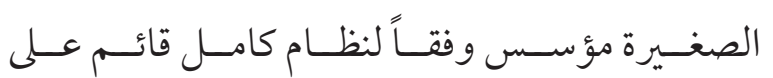

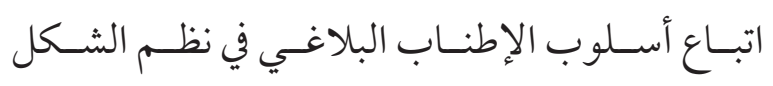
جعـل تلـك الأبنيـة معسبرة ومثـيرة.

عـلى الرغـــم مــن اختــلاف النــوع الوظيفـي

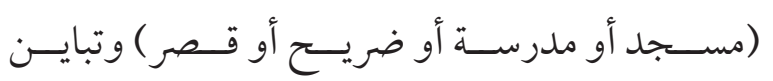

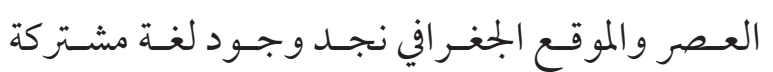

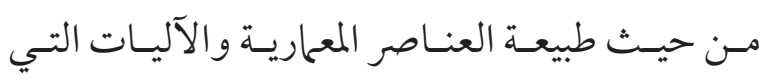

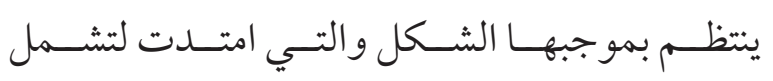

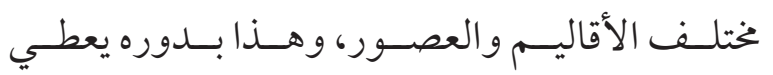

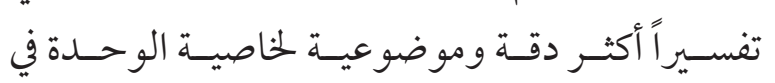

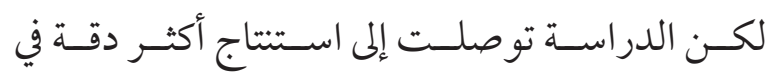

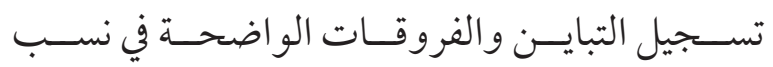

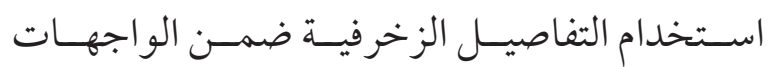

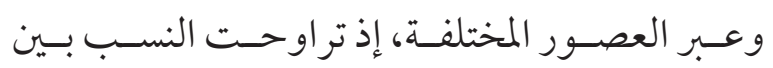

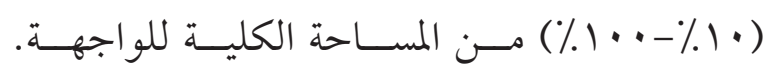

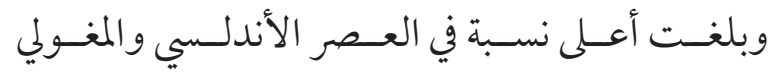

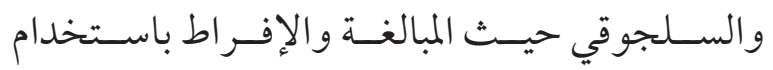

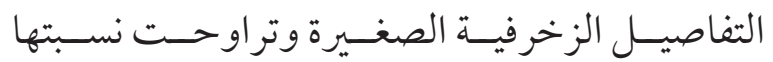

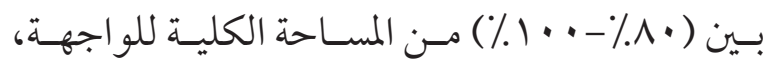

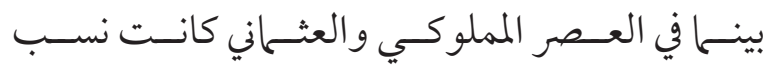

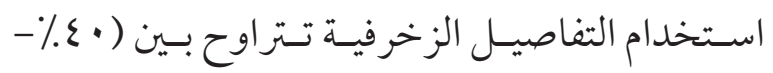

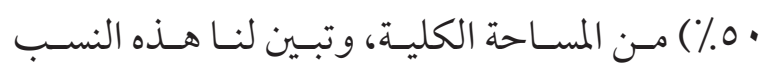

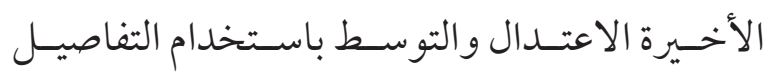

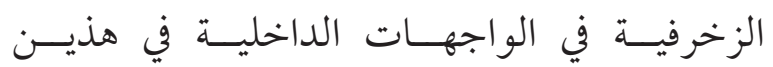

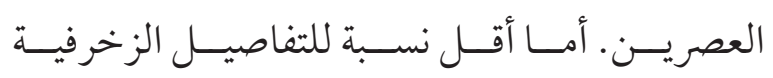

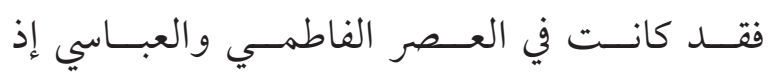

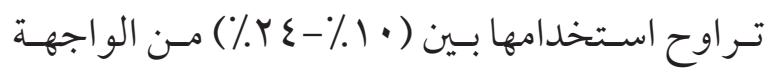

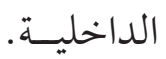

الاسـتنتاجات المتعلقــة بالكشـف عـن وجـود

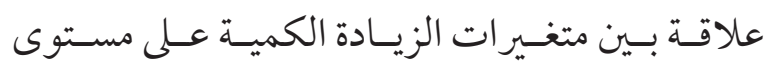

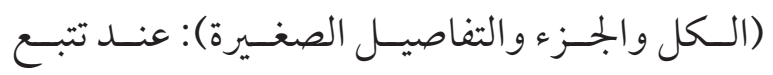

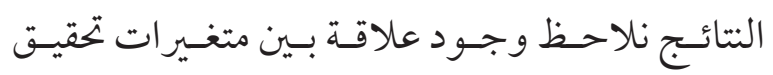

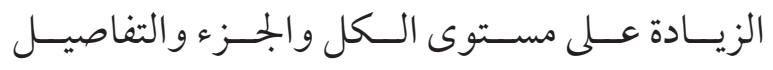

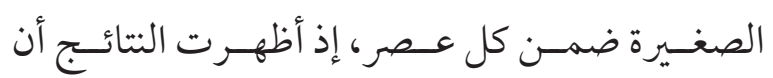
العـصر الأندلـسي وبشـكل ميـز حقـق ارتفاعـاً كبـيراً

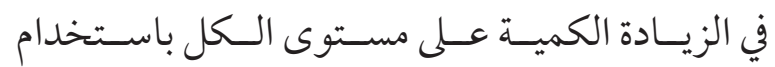

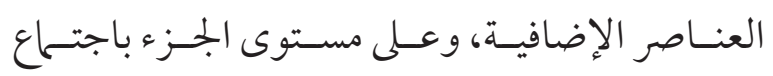

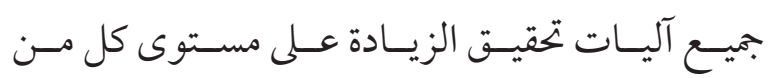


ابــن الاثـــــ ضيــاء الديــن. المثــل الســائر في ادب

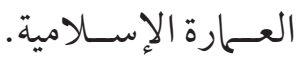

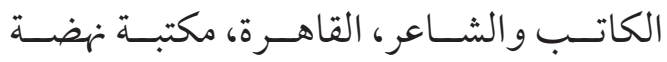
مـصر ومطبعتهـا، قدمـه وحققــه وعلـق عليـه:

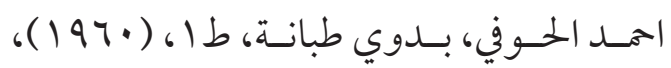

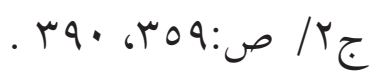

ابــن منظــور؛ لســان العـرب. بــيروت، دار لســان

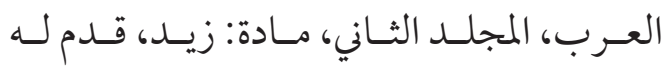

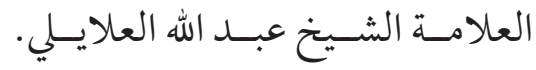

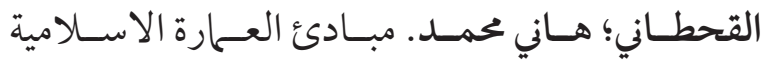

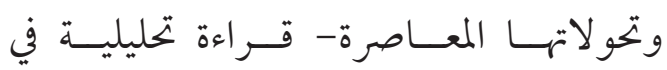

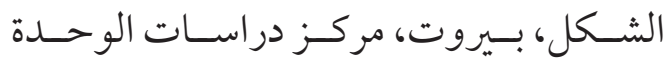

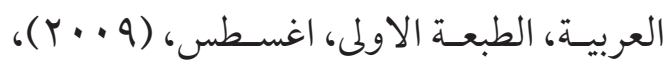
ص:V

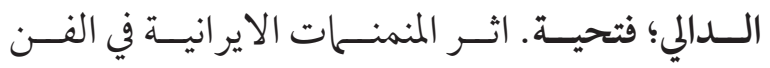

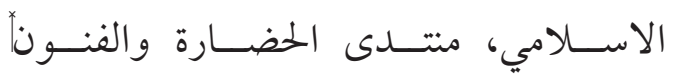
$(r \cdot 11)$

الحـــداد، نظـــم القـــــان والكتـــاب، الكتـــاب الاول:

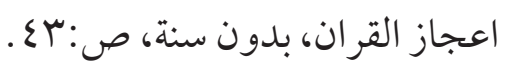

الجاحـظ، ابـو عثـان. الحيـوان، بـيروت، دار ومكتبـة

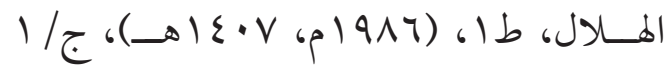
ص: صن

العسـكري، ابــو هــلال الحسـن بــن عبــد الله.

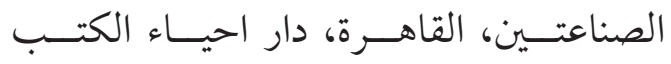

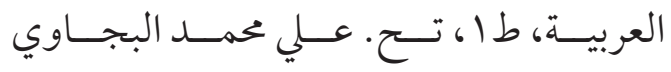

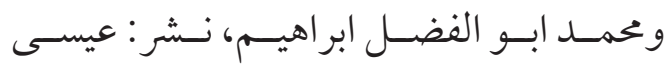

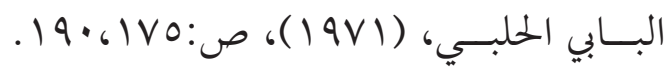

بــين البحــث أن الشـكل في العـارة الإسـلامية

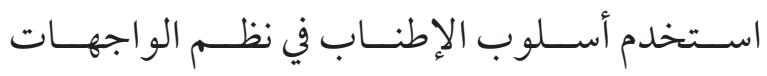

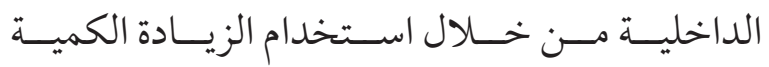

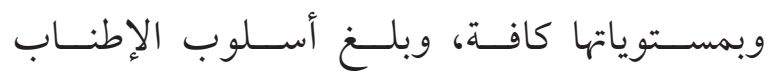

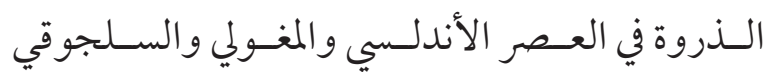

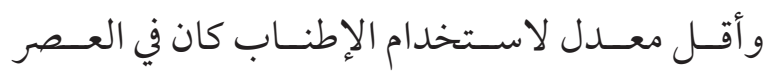

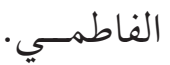

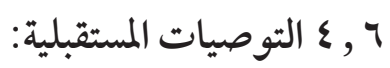
يــوصي البحــث بالاسـتفادة مــن أســاليب

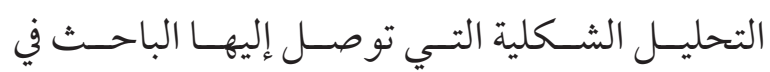

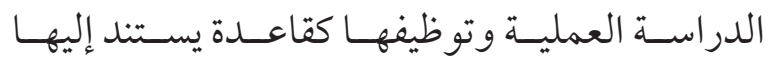

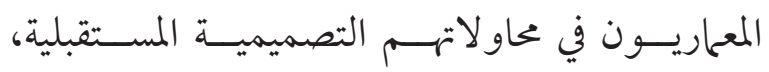

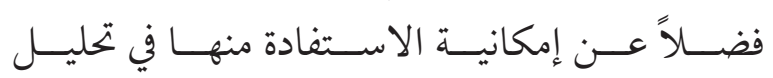

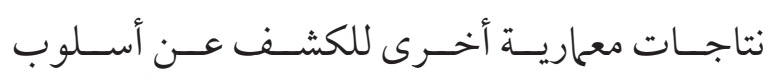
الإطنـاب فيهـا. أنسات

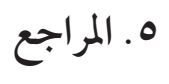

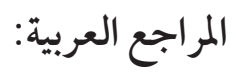

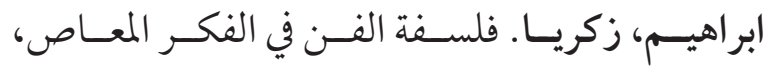

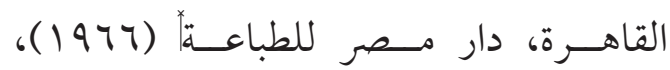
ص:

أبـو المـكارم؟ عـلي. أصـول التفكـير النحـوي، ليبيـا،

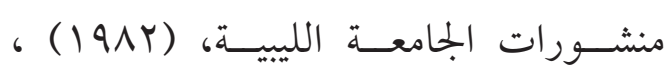
ص 
‘(lcriture Par Roland Barthes ed: Seyil 1953

$$
\text { NV:بـدون ســنة)، صـ }
$$

ثوينسي، عـلي. معجــم عـمارة الشـعوب الاسـلامية،

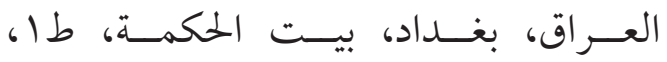

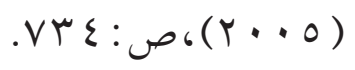

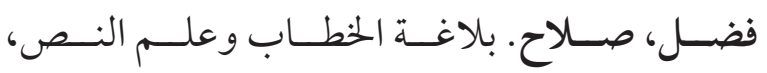

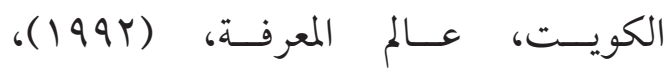

$$
\text { ص: }
$$

قطــب، ســيد. التصويــر الفنــي في القــران،

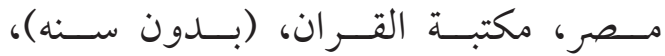

$$
\text { 1.1.1.0.90: }
$$

عبــد المطلــب، محمــد. البلاغــة والاسـلوبية، القاهـرة،

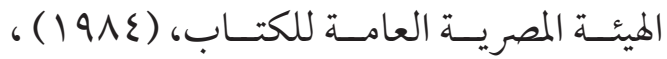

$$
\text { ص:qu }
$$

عرفـة، عبــ العزيـز عبـــ المعطي. مــن بلاغـة النظـم العـربي، دراسـة تحليليـة لمســائل علـم المعـاني،

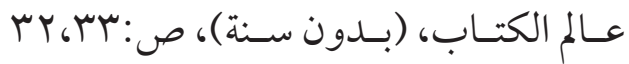

عنـتر، سـالم حمـادي. التحليـل الاحصائسي في البحـث

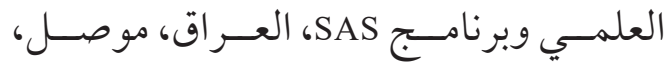

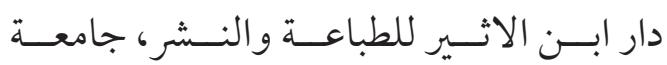

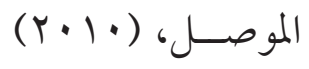

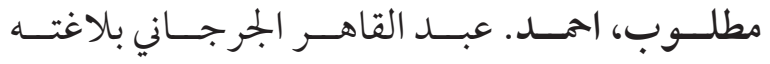

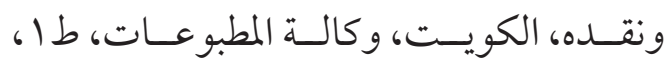

$$
\text { 77:ص (19VM) }
$$

محمـــود، امــل حمــد. بحـــث في جماليــات المنمنمــة
الزخـشـري، أبـو القاســم محمــود بــن عمــر ـ أســاس

البلاغــة، بــيروت، دار صــادر للطباعــة

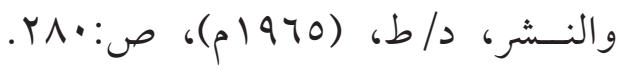

الجرجـــاني، عبـد القاهـر. دلائـل الاعجــاز، بـيروت،

دار المعرفـة، ط ال، وقـف عـلى تصحيـح طبعـهـ

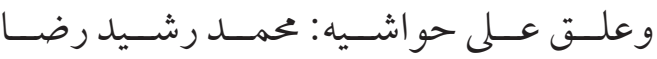

(p)

الفــروز آبـادي. القامـوس المحيـطـ، دمشـق، مكتبــة

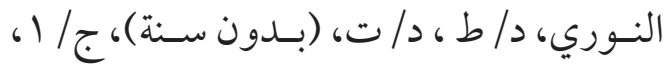

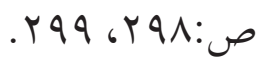

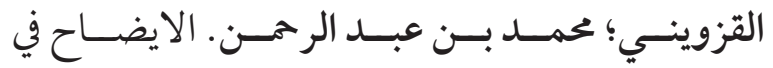

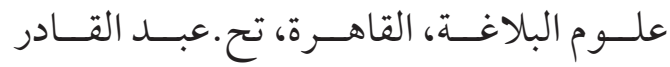

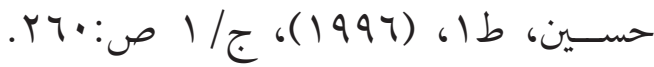

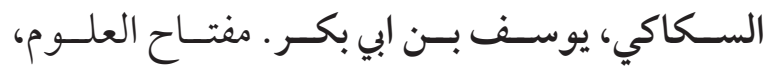

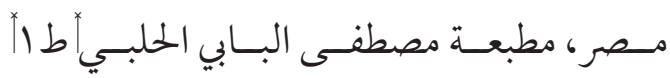

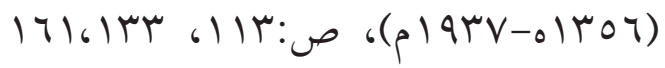
الامــام، محمـــد وليــد يوســف. تحـــــاتلات الشـكل المعــاري، تحـول الشـكل وتكامـل الخصائص،

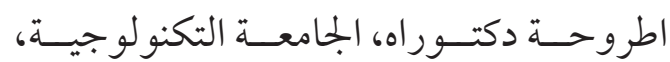
(r) باديسـ، نـور الهـدى. بلاغـة الوفــرة وبلاغـة النـدرة، مبحــث في الاييــاز والاطنـاب، بــدون ســنة، صY:

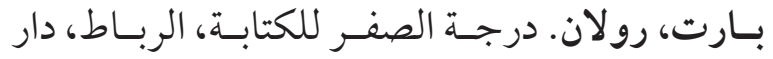

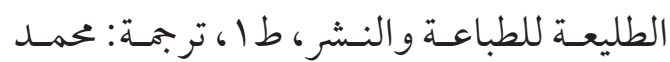

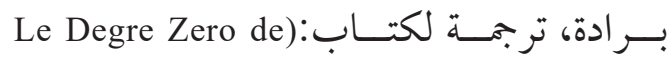


p: 190,175

Al-Zamakhshari; Abu al-Qasim Mahmud bin Umar, "Basis Of Rhetoric", Beirut, Dar Sadir for Printing and Publishing, D / T (1965), p:280

Al-Jarjani, Abd al-Qaher, "Evidence of Miracles", Beirut, Dar al-Maarifah, 1,

Al-Fayrose Abadi, "The Surrounding Dictionary", Damascus, Al-Nouri Library, D / T / D / T (Without a Year), C / 1, p: 298, 299

Al-Qazwaini; Muhammad Ibn Abd al-Rahman, "Explanation In The Sciences of Rhetoric", Cairo, ed: Abdul Qader Hussain, I, (1996), c /1, p: 260

Al-Sakaki; Yusuf ibn Abi Bakr, "Key Of The Science”, Egypt, Mustafa al-Babi al-Halabi Press, 1, (1937), p: 113, 161,133

Al- Imam, Muhammad Walid Yusuf, "Transformations of Architecture, Shape and Integration of Properties", Ph.D. University of Technology, (2002), p:23

Badis; Nour Al-Huda, "The Rhetoric of Abundance And Rhetoric of Scarcity", a study in the Briefness and the Verbosity, (without a year), p:72

Barth; Roland, "The Zero Degree of Writing", Rabat, Dar al-Tali'ah for Printing and Publishing, 1, translated by: Mohamed Barrada, translation of Le Degre Zero de lcriture Par Roland Barthes, ed: Seyil, (1953), P:87

Thwaini; Ali, "Dictionary Of The Architecture of Islamic Peoples", Iraq, Baghdad, Bayt Al-Hikma, 1, (2005), p:734

Fadl, Salah, "The Rhetoric Of Text And Discourse", Kuwait, The World of Knowledge, (1992), p:133,134

Qutb; Sayed, "Artistic Photography in the Qur'an", Al-Qur'an Library, (without a year), p:108,105,95

Abd al-Muttalib, Muhammad, "The Calligraphy and Stylistics", Cairo, The Egyptian Gener-

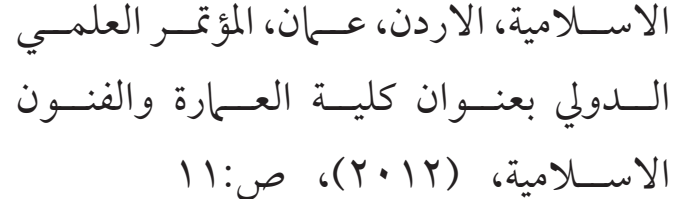

Arabic References:

Ibrahim, Zakaria, "The Philosophy Of Art In Contemporary Thought", Cairo, Egypt Printing House, (1966), p: 81,82

Abu Al-Makarem, Ali, "Principles of Grammar Thinking" Libya, University of Libya Publications, (1982), p: 307

Ibn al-Atheer; Diaa Al-Din, "The Proverbs in the Literature of the Writer and the Poet ", Cairo, Nahdet Egypt Library and its Printing, presented and realized by: Ahmad Al-Houfi, Badawi Tabaneh, (1960).

Ibn Maswar, "The Arabic Language", Beirut, Dar al-San al-'Arab, Volume Two, Article: "Zaid".

Al-qahtany; Hani Mohamad, "The Principles of Islamic Architecture and Contemporary Transformations - An Analytical Reading in Form", Beirut, Center for Arab Unity Studies, First Edition, August, 2009, p:207.

Dali, Fathia, "The Influence of Iranian Minimans in Islamic Art", Forum of Civilization and the Arts, (2011)

Al-Hadad; "systems of the Koran and the book" the first book: the miracle of the Koran, (without a year)

Al-Jahiz; Abu Othman, “Al-Hayewan ” Beirut, Dar and the Library of the Crescent, 1, (1986), c $/ 1 \mathrm{p}: 59.58$

Al-Askari; Abu Hilal Hassan bin Abdullah, "Al-Senaetyn", Cairo, House of Arabic books, I, 1. Ali Mohammad al-Bagawi and Muhammad Abu al-Fadl Ibrahim, published by: Iessa Al-Babi Al-Halabi, (1971), 


$$
\text { أنوار مشعل شريف؛ حفصة رمزي العمري : بلاغة الشكل في العمارة الإسلامية: دراسة تحليلية لأسلوب الإطناب. }
$$

Jencks, C. "The Architectural Sign- in Sign Symbols, and Architecture", John Wiley \& Sons Ltd.( 1980), p:89,91.

JO- Tonna, "The Poetics Of Arab-Islamic Architecture", Department Of Architecture And Urban Design, University Of Malta Msida, (1990) p:178 ,182, 187,188,191 p:187m p. 187 .

Mitchell, W. "The logic Of Architecture", Cambridge Mass, The MIT Press, (1992), p:131,132, 162,146, p.135 ,136, 106,107, $131,132$.

Michell, G. and others, "Architecture Of The Islamic World" Thames and Hudson Ltd, London, (1978), p:149.

Metzger, W., "Laws Of Seeing”, London, England,The MIT Press Cambridge, Massachusetts Institute of Technology, Copyright: W. Kramer \& Co, translated by Lothar Spillmann, Steven Lehar, Mimsey Stromeyer, and Michael Wertheimer, (2006), p:20-27.

Salingaros, N. , Klinger, A. "A Pattern Measure ,Complexity and Visual Images", Los Angeles, School Of Engineering And Applied Science, University Of California, (2000).

Salingaros, N."Life And Complexity In Architecture From A Thermodynamic Analogy", Physics Essays Publications, (1997).

Venturi, R. "Complexity And Contradiction In Architecture", New York, (1977), p:36 88,16, $17,61,62$.

Yeomans, R., "The Art And Architecture Of Islamic Cairo", Egybt, (2006), p:193, 206, 206, 208 . al Book Organization (1984), p:39

Arafa; Abdul Aziz Abdul Muti, "From the rhetoric of the Arab systems, an analytical study of the issues of theology", World of the Book, (without a year), p:32-33

Antar, Salem Hammadi, "Statistical Analysis in Scientific Research and SAS Program", Iraq, Mosul, Dar al-Atheer for Printing and Publishing, Mosul University, (2010)

Muttalob, Ahmad, "Abdel-Qaher Al-Jarjani, his statement and criticism",Kuwait, the Press Agency, I, (1973), p:66

Mahmoud, Amal Hamad, "Research in the aesthetics of Islamic miniatures", Jordan, Amman, International scientific conference entitled,Faculty of Architecture and Islamic Arts", (2012), p:11

\section{English References:}

Broadbent, G. "Introduction To Section 2 in -Sign Symbols, and Architecture" John Wiley \& Sons Ltd. (1980), p:206.

Bentley, Alcock, Murrain, Meglynn, Smith, "Responsive Enviroment", London, British library, Amanual For Designers, (1985), p:90.

Castera, J. "The muqarnas Dom Of The Two Sisters In The Alhambra In Granada” (2006), p:102, 103, 1o5, 106, 93, 95, 97, 102,107.

Golombek, L. "The Function Of Decoration In Islamic Architecture", Theories and Principles of Design in Architecture of Isamic Societies, Cambridge, the Aga Khan, ,(1988).

Grabar, O., "Architecture \& Art; In The Genius Of Arab Civilization", Phaidom, source of renaissance, J.R. Hales (editor), (1978), p:91-92.

Harbison, R. “Travels In The History Of Architecture", British Library, (2009), p:127.

Hoag, J. "Islamic Architecture ,History Of World Architecture",Mila, Faber, Electa Editrice, (1975), p:90-92. 


\title{
The Rhetorical Form in Islamic Architecture: Analytical Study of the Verbosity Style
}

\author{
Anwar Meshal Shareef \\ Hafsa Ramzi Al-Omari \\ Assistant Teacher \\ Professor \\ Department of Architecture, University of Al Mosul \\ Anwar_shareef@yahoo.com
}

Received 21/10/2018; accepted for publication 4/2/2019

\begin{abstract}
The problem of this research is the existence of unethical professional issues and practices in the construction industry. It is important to identify and understand those types of unethical issues and practices in order to avoid and prevent ethical lapses. The research methodology is based on previous studies on the ethics of building construction and on tracking the professional ethical issues that have occurred in building construction in Saudi Arabia during the past ten years. The research included analyzing case studies that were tracked and collected from several sources. Twenty (20) major cases were reviewed in construction projects to identify relevant ethical issues in construction projects in Saudi Arabia. The results indicate that there are many different types of ethical issues that occurred in building construction, which were classified as fraud and collusion. Fraud in forging documents got the highest percentage (38\%), while the highest percentage of collusion was $(20 \%)$ in conspiracy among professionals. These results indicate the need for more focus on improving ethical performance in the building construction sector through laws, education, government bodies and scientific societies
\end{abstract}

Key words: Ethical Issues; Building Construction; Unethical Behavior; Collusion; Fraud. 
7. الملاحق

جدول رقم (ه).النحاذج المنتخبة من عصور اسلامية مختلفة (المصادر: (Castera,2006), (JO) (Michell,1978), (C) 1975), (C) ((Tonna,1990), (Golombek, 1988

\begin{tabular}{|c|c|c|c|c|c|}
\hline النوع الوظيفي & سنة الإنجاز & الموقـع الجغر افي & النحاذج المتتخبة & 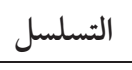 & العصر \\
\hline مسجد & 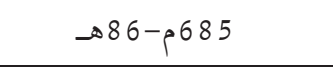 & فلسطين & قبة الصخرة & 1 & العصر الاموي \\
\hline مسجد & م & تونس & مسجد القيروان & 2 & العصر العباسي \\
\hline مسجد & م55هـ - 1160م & مصر & جامع الصالح طلائع & 3 & \multirow{2}{*}{ العصر الفاطمي } \\
\hline مسجد & 830هـ - 8909 & مصر & جامع الحاكم & 4 & \\
\hline ضريح & 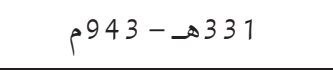 & ايران & ضريح ساماندس & 5 & \multirow{4}{*}{ السلجوقي } \\
\hline ضريح & 720هـ - 1320م & 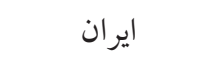 & ضريح ركن الدين & 6 & \\
\hline ضريح & 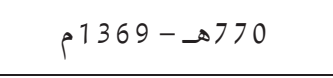 & ايران & ضريح ترابيك خانم & 7 & \\
\hline مسجد & ما & ايران & مسجد اصفهان & 8 & \\
\hline ضريح & م1211-ه08 & مصر & قبة الامام الشافعي & 9 & \multirow[t]{2}{*}{ العصر الايوبي } \\
\hline ضريح & م640هـ-1242م & مصر & قبة الخلفاء العباسيين & 10 & \\
\hline مسجد & $\rightarrow 735$ & مصر & جامع الناصر محمد & 11 & \multirow{4}{*}{ المملوكي } \\
\hline مسجد وضريح & $-8683-684$ & مصر & مدرسة وقبة قلاون & 12 & \\
\hline مرسة وجامع & ه764-757 & مصر & مدرسة وجامع السلطان حسن & 13 & \\
\hline مدرسة & م & مصر & مدرسة قيتباي & 14 & \\
\hline مسجد & - $7774-987$ & 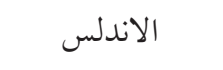 & مسجد قرطبة & 15 & \multirow{2}{*}{ الاندلسي } \\
\hline قصر & م & غرناطة & قصر الحمراء & 16 & \\
\hline مسجد & م & 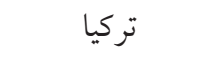 & مسجد بورصة & 17 & \multirow{5}{*}{ العصر العثلني } \\
\hline مسجد & م3509-1528م & مصر & جامع سليمان باشا & 18 & \\
\hline مسجد & م & ت ت تركيا & مسجد السليمانية & 19 & \\
\hline مسجد & م & 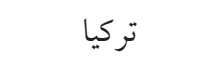 & مسجد السليمية & 20 & \\
\hline مسجد & $1246-1265$ & مصر & جامع محمد علي & 21 & \\
\hline ضريح & م & الهند & ضريح التوتش & 22 & \multirow[t]{2}{*}{ العصر المغولي } \\
\hline مسجد & م & باكستان & مسجد وزير خان & 23 & \\
\hline
\end{tabular}




$$
\text { جدول رقم (7 ).يوضح رسم العينات المنتخبة باستخدام برنامج الاوتو كاد. }
$$

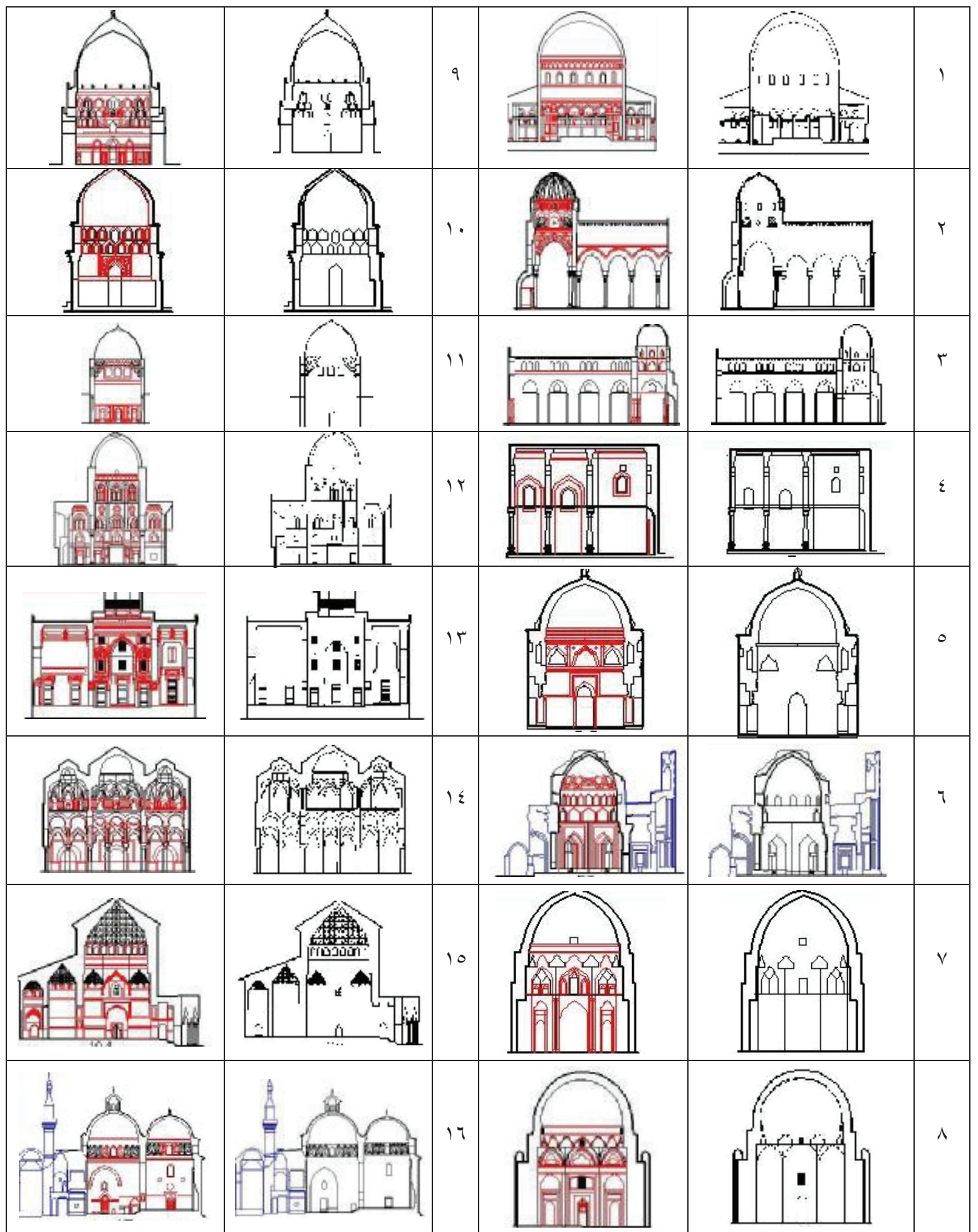




$$
\text { أنوار مشعل شريف؛ حفصة رمزي العمري : بلاغة الشكل في العمارة الإسلامية: دراسة تحليلية لأسلوب الإطناب. }
$$

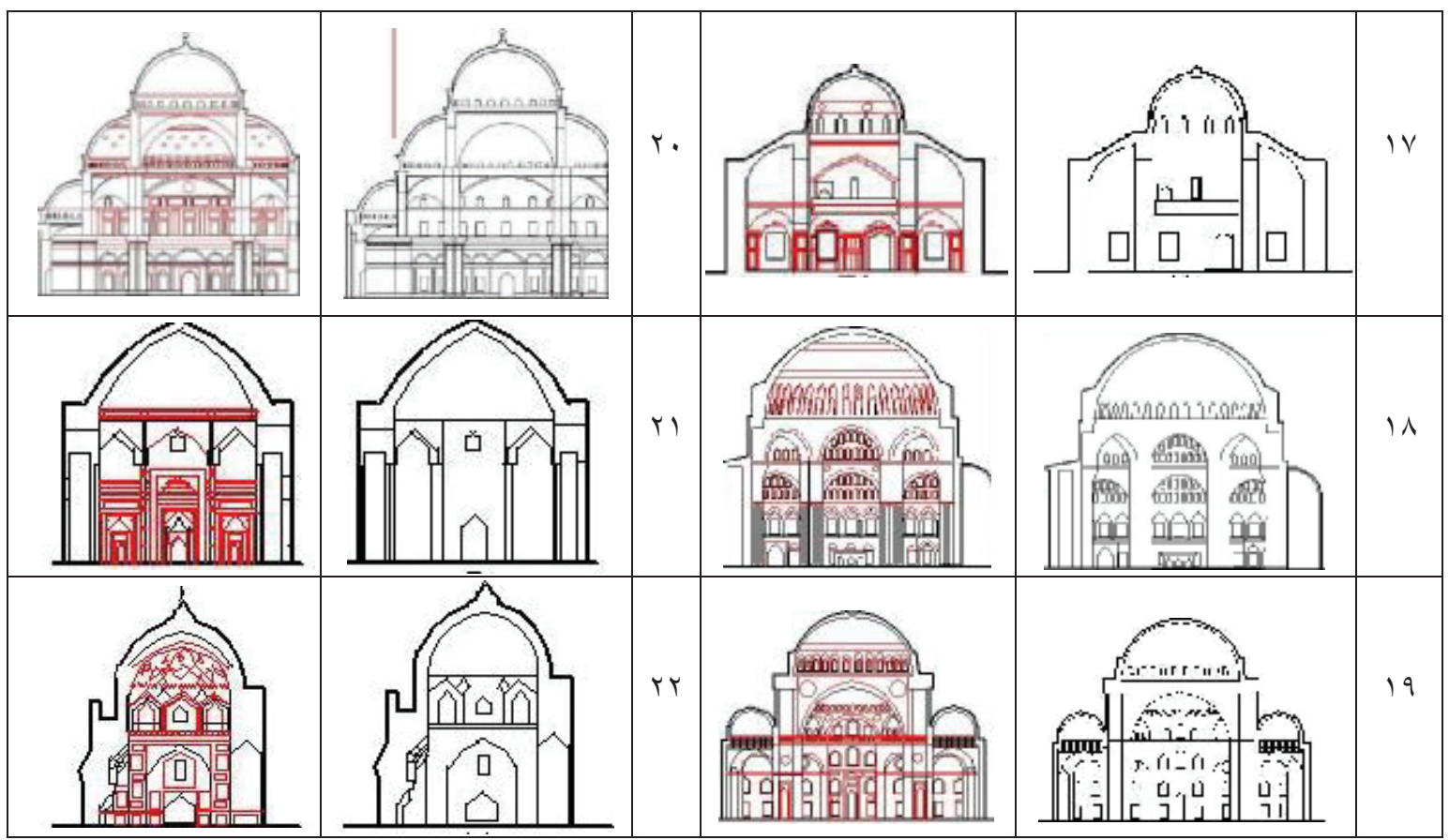


جدول رقم (V). عدد العناصر الاساسية والاضافية في النهاذج المنتخبة.

\begin{tabular}{|c|c|c|c|}
\hline عدد العناصر الاضافية في ·' امF' & عدد العناصر الاساسية في ·” امب & النموذج & 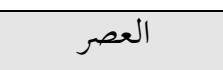 \\
\hline ir & $1 \cdot$ & مسجد بور صة & العصر العثماني \\
\hline $1 \varepsilon$ & 11 & مسجد السليانية & \\
\hline ir & 1 . & مسجد السليمية & \\
\hline $1 \varepsilon$ & $\wedge$ & مسجد سلي|ن باشا & \\
\hline 7 & $\varepsilon$ & جامع محمد علي & \\
\hline 19 & $\circ$ & ضريح Samanids & العصر السلجوقي \\
\hline rt & 7 & ضريح Torabec & \\
\hline 11 & 0 & المسجد الجامع في اصفهان & \\
\hline $1 \varepsilon$ & $\varepsilon$ & ضريح ركن الدين & \\
\hline$r 1$ & 9 & مسجد قرطبة & العصر الاندلسي \\
\hline ro & 0 & قصر الحمراء & \\
\hline ro & 0 & ضريح ILTUTMISH & 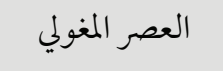 \\
\hline rA & 9 & مسجد وزير خان & \\
\hline$r \cdot$ & ir & قبة الصخرة & العصر الاموي \\
\hline 1. & 7 & جامع القيروان & 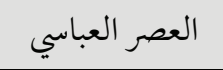 \\
\hline 11 & $\wedge$ & قبة الامام الشافعي & العصر الايوبي \\
\hline r & 10 & قبة الخلفاء العباسين & \\
\hline 17 & $1 \cdot$ & جامع ومدرسة الناصر محمد & العصر المملوكي \\
\hline 9 & 0 & جامع ومدرسة السلطان حسن & \\
\hline YI & 9 & مدرسة وقبة قيتباي & \\
\hline 19 & v & مدرسة وقبة قلاون & \\
\hline r & v & 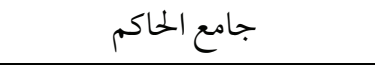 & العصر الفاطمي \\
\hline 7 & 0 & جامع الصالح طلائع & \\
\hline
\end{tabular}


جدول رقم (^). يوضح الزيادة الحاصلة على مستوى الكل والجزء والتفاصيل.

\begin{tabular}{|c|c|c|c|c|c|c|c|c|c|c|c|c|c|c|c|c|c|c|c|c|c|c|c|c|c|c|c|c|}
\hline \multirow{4}{*}{ التصفئيلى الزيادي } & \multicolumn{25}{|c|}{ الزيادة على مستوى الجزء } & \multirow{4}{*}{ ملز الزيادى } & \multirow{4}{*}{ 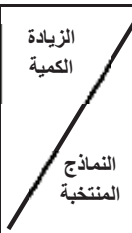 } & \multirow{4}{*}{ العصر } \\
\hline & \multicolumn{5}{|c|}{ انحناء|ت وتعرجات } & \multicolumn{15}{|c|}{ تقسيم } & \multicolumn{5}{|c|}{ تجزئة } & & & \\
\hline & \multirow[b]{2}{*}{ ? } & \multirow[b]{2}{*}{.9. } & \multirow[b]{2}{*}{\begin{tabular}{|l|l}
9 \\
9 \\
\end{tabular}} & \multirow[b]{2}{*}{$\frac{2}{2}$} & \multirow{2}{*}{\multicolumn{2}{|c|}{3}} & \multicolumn{4}{|c|}{ علامات خطية } & \multicolumn{5}{|c|}{ علامات زخرفية } & \multicolumn{5}{|c|}{ علامات لونية } & & & & & & & & \\
\hline & & & & & & & . & : & $\frac{2}{2}$ & 3 & 哥 & g. & : & $\frac{1}{2}$ & 繁 & : & : & : & 量 & 3 & : & . & : & 㝵 & 等 & & & \\
\hline$\% \vee 4$ & & & 1 & 1 & 1 & & & 1 & 1 & & 1 & 1 & & & 1 & 1 & 1 & & & 1 & & & & & & $r, \varepsilon$ & قبة الصخرة & الاموي \\
\hline$\%$ \% & & 1 & 1 & 1 & 1 & & 1 & 1 & 1 & 1 & 1 & & & & & 1 & & & & & & & 1 & 1 & & $r, v$ & جامع القيروان & العباسي \\
\hline$\%$ & & & 1 & 1 & & & & 1 & 1 & & 1 & & & & & & & & & & & & 1 & & & 1,0 & جامع الحاكم & الفاطمي \\
\hline$\% 1 r$ & & & & 1 & & & & & 1 & & 1 & & & & 1 & & & & & & & & & & & $r, r_{O}$ & جاملع الصالح & الفاطمي \\
\hline$\% \wedge$. & & & 1 & 1 & & 1 & & 1 & 1 & 1 & & & & & & & & & & & & & 1 & 1 & & $\varepsilon, 7$ & $\begin{array}{c}\text { ض } \\
\text { Samanids }\end{array}$ & السلجوقي | \\
\hline$\% \vee \vee$ & & & & & & & & 1 & & & & 1 & & & & & & & & & & & 1 & & & $\varepsilon, r$ & $\begin{array}{c}\text { ض } \\
\text { Torabec }\end{array}$ & السلجوقي \\
\hline$\% 1 \ldots$ & & & 1 & & 1 & & & 1 & 1 & 1 & 1 & 1 & & & & & & & & & & & 1 & 1 & & $\varepsilon, 0$ & الميجد الجامع & السلجوقي |المي \\
\hline$\% 9 \leq$ & & & 1 & & 1 & & & & & & 1 & 1 & 1 & & 1 & & & & & & & & 1 & & 1 & $\varepsilon, Y_{0}$ & ضريح ركن الدين & السلجوقي | \\
\hline$\%$. & & & 1 & 1 & & & 1 & 1 & & 1 & 1 & 1 & 1 & & 1 & & & & & & & & 1 & & & $r, \leqslant 4$ & أشبافة الامام & الايوبي \\
\hline$\% \leqslant r$ & & & 1 & & 1 & & & 1 & & 1 & 1 & 1 & 1 & & 1 & & & & & & & & 1 & & 1 & $r$ & قألبة الخلفاء & الايوبي \\
\hline$\%$ \% V & & & 1 & 1 & & & & 1 & 1 & & 1 & & 1 & & & & & & & 1 & & & 1 & & & $Y, Y$ & جامنع ومدرسة & المملوكي \\
\hline$\% \varepsilon$ & & & 1 & & & & & 1 & 1 & & 1 & & 1 & & & & & & & 1 & & & 1 & & & $r, 7$ & السططي ومدرسنة & المملوكي \\
\hline$\% \wedge r$ & & & & 1 & 1 & & & 1 & 1 & & 1 & & & 1 & 1 & \begin{tabular}{|l|l}
1 \\
\end{tabular} & & & 1 & & & & 1 & & & $r, \xi$ & مدارسة وقبة & المملوكي \\
\hline$\% 9 \mathrm{~V}$ & & & & 1 & 1 & 1 & & & 1 & & 1 & & & & & 1 & & & & 1 & & & & & 1 & $\Gamma, \varepsilon$ & مدرسة وقبة & الملوكي \\
\hline$\%$ \%r & & 1 & 1 & 1 & 1 & & 1 & & 1 & & 1 & 1 & 1 & & 1 & & 1 & 1 & & 1 & & & 1 & 1 & 1 & $\varepsilon, 7$ & مسجد قرطبة & الاندلسي \\
\hline$\% 9 \mathrm{~V}$ & & 1 & 1 & 1 & 1 & & 1 & & 1 & & 1 & 1 & 1 & 1 & 1 & & 1 & \begin{tabular}{l|l}
1 \\
\end{tabular} & & & & 1 & 1 & 1 & 1 & $0, Y$ & قصر الحمراء & الاندلسي \\
\hline$\% \mu v$ & & & 1 & & & 1 & & 1 & & 1 & 1 & & 1 & & & & & & & & & & 1 & & & $r, 1$ & مسجد بورصة & العثماني \\
\hline$\% 41$ & & & 1 & & & & & 1 & & 1 & 1 & 1 & & & 1 & & 1 & & & & & & & & & $r, V$ & مسجد سليمان & العثاني \\
\hline$\%$ \%V & & & 1 & 1 & & & & 1 & 1 & 1 & 1 & 1 & & & & \begin{tabular}{|l|l|}
1 \\
\end{tabular} & 1 & & & 1 & & & 1 & & & $r, r$ & مسجد أسليمانية & العثماني \\
\hline$\%$ \% & & & 1 & 1 & & & & & 1 & & 1 & 1 & & & & 1 & 1 & & & 1 & & & 1 & & & $Y, Y$ & مسجد السليمية & العثماني \\
\hline$\% ० 1$ & & & 1 & 1 & & & & 1 & & & 1 & 1 & & & 1 & 1 & 1 & & & 1 & & & 1 & & & $r, r$ & جامع محمد علي & العُماني \\
\hline$\% \wedge$ & & & 1 & 1 & 1 & & & 1 & 1 & & & & & 1 & 1 & & & & & & & & 1 & 1 & & 0,7 & $\begin{array}{c}\text { ضريح土 } \\
\text { ILTUTMISH }\end{array}$ & المغولي \\
\hline$\% 94$ & & 1 & 1 & & 1 & & & & & & 1 & 1 & 1 & & 1 & 1 & 1 & 1 & & 1 & & 1 & 1 & & 1 & $\xi$ & مسجد وزير خان & المغولي \\
\hline
\end{tabular}


1, 1 الجداول الخاصة بالنتائج الاحصائية:

جدول رقم (Y Y ) يوضح معدل استخدام الية الانحناءات

\begin{tabular}{|c|c|}
\hline الية الانحناءات والتعرجات & العصر \\
\hline 0.37 & العصر الفاطمي \\
\hline 0.30 & العصر السلجوقي \\
\hline 0.4 & العصر الايوبي \\
\hline 0.25 & العصر المملوكي \\
\hline 0.8 & العصر الاندلسي \\
\hline 0.36 & العصر العثماني \\
\hline 0.6 & العصر المغولي \\
\hline
\end{tabular}

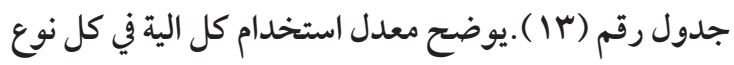
من انواع العناصر في العمارة الاسلامية

\begin{tabular}{|c|c|c|c|}
\hline \multicolumn{3}{|c|}{ الالية } & \multirow[t]{2}{*}{ العنصر } \\
\hline الانحناءات والتعرجات & التجزئة & التقسيم & \\
\hline 0.38 & 0.3 & 0.9 & قوس \\
\hline 0.62 & 0.3 & 0.75 & عمود \\
\hline 0.8 & 0.85 & 0.9 & قاعدة قبة \\
\hline 0.14 & 0.15 & 0.7 & قبة \\
\hline 0.00 & 0.00 & 0.9 & فتحة \\
\hline
\end{tabular}

جدول رقم (؟ 1 ). يوضح معدل استخدام الية التجزئة في

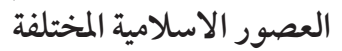

\begin{tabular}{|c|c|}
\hline الية التجزئة & العصر \\
\hline 0.1 & العصر الفاطمي \\
\hline 0.35 & العصر السلجوقي \\
\hline 0.3 & العصر الايوبي \\
\hline 0.2 & العصر المملوكي \\
\hline 0.7 & العصر الاندلسي \\
\hline 0.16 & العصر العثماني \\
\hline 0.5 & العصر المغولي \\
\hline
\end{tabular}

\begin{tabular}{|c|c|c|c|}
\hline المعدل العام & الزيادة على & معدل الزيادة & العصر \\
\hline للزيادة الكمية & مستوى & على مستوى & \\
\hline بكافة مستوياتها & التفاصيل & الكل ال & \\
\hline 0.41 & 0.11 & 1.88 & الفاطمي \\
\hline 0.78 & 0.88 & 4.41 & السلجوقي \\
\hline 0.66 & 0.41 & 3.23 & الايوبي \\
\hline 0.56 & 0.59 & 2.9 & المملوكي \\
\hline 1.08 & 0.89 & 4.9 & الاندلسي \\
\hline 0.58 & 0.51 & 2.32 & العثماني \\
\hline 0.89 & 0.88 & 4.8 & المغولي \\
\hline
\end{tabular}

جدول رقم ( • ( ) . يوضح معدل استخدام الية التقسيم في العصور الاسلامية المختلفة.

\begin{tabular}{|c|c|}
\hline الية التقسيم & العصر \\
\hline 0.6 & العصر الفاطمي \\
\hline 0.75 & لعصر السلجوقي \\
\hline 0.8 & العصر الايوبي \\
\hline 0.85 & العصر المملوكي \\
\hline 1 & العصر الاندلسي \\
\hline 0.8 & العصر العثلماني \\
\hline 0.8 & العصر المغولي \\
\hline
\end{tabular}

جدول رقم (11) . يوضح معدل تحقق الزيادة بكافة مستوياتها

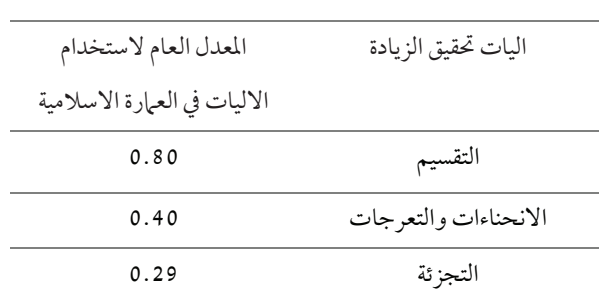

